João Diogo Urias dos Santos Filho

\title{
DIREITO À OCUPAÇÃO E CONTINUAÇÃO DE EMPRESAS VIA GESTÃO OPERÁRIA soluções jurídicas a partir de casos brasileiros
}

\author{
Dissertação de Mestrado \\ Orientador: Professor Dr. Guilherme Guimarães Feliciano
}

Universidade de São Paulo - Faculdade de Direito

São Paulo

2014 


\title{
DIREITO À OCUPAÇÃO E CONTINUAÇÃO DE EMPRESAS VIA GESTÃO OPERÁRIA
} soluções jurídicas a partir de casos brasileiros

\author{
Dissertação de Mestrado apresentada ao Departamento \\ de Direito do Trabalho e da Seguridade Social da \\ Faculdade de Direito da Universidade de São Paulo \\ como requisito parcial para obtenção do grau em \\ Mestre em Direito do Trabalho e da Seguridade Social. \\ Orientador: Professor Dr. Guilherme Guimarães \\ Feliciano
}

Universidade de São Paulo - Faculdade de Direito

São Paulo 
João Diogo Urias dos Santos Filho

\section{DIREITO À OCUPAÇÃO E CONTINUAÇÃO DE EMPRESAS VIA GESTÃO OPERÁRIA: soluções jurídicas a partir de casos brasileiros}

Dissertação de Mestrado apresentada ao Departamento de Direito do Trabalho e da Seguridade Social da Faculdade de Direito da Universidade de São Paulo como requisito parcial para obtenção do grau em Mestre em Direito do Trabalho e da Seguridade Social.

Orientador: Professor Dr. Guilherme Guimarães Feliciano

Aprovado em: de de 2014.

\section{BANCA EXAMINADORA}

$1^{\circ}$ membro:

$2^{\circ}$ membro:

$3^{\circ}$ membro:

$1^{\mathrm{o}}$ suplente:

$2^{\circ}$ suplente:

$3^{\circ}$ suplente: 
Dedico este estudo a todos os trabalhadores de empresas recuperadas, que me fornecem inspiração por sua coragem de quebrar as algemas e assumir o controle da própria vida. 


\section{AGRADECIMENTOS}

Há três pessoas sem as quais este trabalho não se realizaria.

Em primeiro lugar minha companheira, Deise, mulher trabalhadora, intelectual singular. O cruzamento de nossos caminhos, no ano de 2007, foi uma revolução em minha vida não só porque aprendi o que era amar, mas, também, porque você me apresentou o mundo da pesquisa científica, no qual entrei e nunca mais saí. Obrigado por tudo, e, especialmente, por seu imenso apoio e paciência nos dias mais difíceis da conclusão desta pesquisa. $\mathrm{O}$ fim do seu mestrado está chegando, saiba que e eu estarei aqui.

Em segundo meu orientador, professor Guilherme Feliciano, por ter confiado em meu trabalho, ter me dado as mãos para acessar o mundo acadêmico e ter sido tão ideologicamente aberto às proposições que eu decidi defender.

Em terceiro o professor Alaôr Caffé Alves, personalidade incrível, marxista convicto, que tive o prazer de conhecer. Agradeço-lhe por ter me recebido com tanta atenção e por ter abalado tanto meus pensamentos nas conversas que precederam a qualificação. Seu as suas provocações e seu exemplo eu não teria consolidado minhas convições ideológicas.

Agradeço, também, ao Alexandre Mandl e ao pessoal da Flaskô, por terem me recebido em visita à fábrica e, no caso do Alexandre, por ter me enviado material de pesquisa precioso.

Por último, mas não menos importante, à minha família maravilhosa, meu pai, minha irmã e meus irmãos, pelo eterno amor e apoio. 
Nós somos aqueles que amassamos

e, ainda assim, não temos pão Nós somos aqueles que escavamos o carvão e, ainda assim, temos frio. Nós somos aqueles que nada temos e viemos tomar o mundo

Tassos Livaditis (poeta grego, 1922-1988)

Em 04 de junho, num final de tarde quente e agradável, aproximadamente mil pessoas se reuniram no pátio da fábrica Vio.Me para conhecer o local, aproveitar a comida e a bebida, dançar a música popular e, mais importante, ouvir Naomi Klein, a aclamada ativista e intelectual canadense, autora de livros reveladores como "No Logo" e

"The shock doctrine". Foi uma noite de otimismo e alegria: a fábrica não é mais um lugar proibido para a comunidade, destinado à produção mecânica e triste de bens a serem comercializados no mercado: a fábrica agora produz para a comunidade, e a comunidade é

parte do processo produtivo, é bem-vinda a percorrer seus espaços, compartilhar as alegrias e tristezas dos trabalhadores, envolver-se no debate político, comer, beber e cantar com eles. Os rostos sorridentes de todos os participantes revelaram seu compromisso renovado com a luta. Porque a luta da Vio.Me por autogestão é a luta de toda a sociedade por dignidade e autodeterminação.

(VIOME.ORG, Junho de 2013)

Temos que tratar de difundir isso, para todo canto: que não se expropria uma fábrica para bem próprio, se expropria para todos os companheiros que estão dentro.

Trabalhador da ex Gip Metal, fábrica metalúrgica argentina ocupada e recuperada pelos operários, hoje Cooperativa Unión y Fuerza (FAJN, 2003, p. 67) 


\section{RESUMO}

Há uma história paralela que acompanhou a vida do sistema social capitalista: a história da ocupação e recuperação de fábricas por trabalhadores. E esse fenômeno se coloca, cada vez mais, com o potencial de abrir novos caminhos para a classe trabalhadora. Este trabalho tem o objetivo de contribuir na prática para o desenvolvimento desse movimento por meio da construção de análises jurídicas passíveis de auxiliar coletivos operários que tenham ocupado ou que se proponham a ocupar empresas em crise. Apesar de termos ciência de que a atuação das instituições jurídicas não é neutra, e têm um caráter contraditório e classista, ainda assim é necessário que os embates jurídicos sejam travados, e, para isso, a classe trabalhadora necessita de formulações jurídicas progressistas. São quatro as problemáticas jurídicas centrais enfrentadas pelas ERTs: a) a licitude da greve de ocupação; b) a necessidade de reconhecimento da gestão operária no procedimento de falência e recuperação empresarial; c) a necessidade, em médio e longo prazo, de estabilização jurídica do ente coletivo, por meio da constituição de uma forma jurídica adequada e d) a carência, em geral, de outras políticas públicas específicas, especialmente as que possibilitem o acesso a crédito. Considerando esse quadro, este trabalho tem dois focos específicos: em primeiro lugar, desenvolver um estudo acerca das bases constitucionais que podem ser utilizadas para o enfrentamento de todas as questões jurídicas. E, em segundo, propor solução a uma das questões mais espinhosas: a da licitude da greve ativa - aquela que se dá com ocupação para produzir. Na primeira parte, concluímos que os três princípios constitucionais que têm relação fundamental com as questões jurídicas que emergem nesses processos - o princípio da função social da propriedade, o princípio do valor social do trabalho e da livre iniciativa e o princípio do direito ao trabalho - têm o efeito de proferir mandamentos para os agentes jurídicos no sentido de criar leis, desenvolver políticas públicas, proibir a realização de atos contrários e interpretar o sistema normativo de modo a favorecer o desenvolvimento das recuperações. Depois, concluímos que a greve de ocupação - passiva ou ativa - será lícita se deflagrada no interior de determinados contextos e respeitando certas condições. A greve ativa, em especial (aquela que se dá com a intenção de produzir), será lícita, a partir de um confronto com os princípios da Constituição à luz da Teoria dos Direitos Fundamentais, se for deflagrada como resposta a uma crise aguda na empresa, gerada por má gestão ou acompanhada de atos de máfé empresarial, que são atos que implicam numa violação grave das responsabilidades sociais estabelecidas pela ordem jurídica para o controlador de bens de produção.

Palavras-chave: Controle operário da produção. Empresas Recuperadas por Trabalhadores. Greve com ocupação. Função social da propriedade dos bens de produção. 


\begin{abstract}
There is a parallel story that accompanied the capitalist social system: the story of the occupation and recovery of factories by workers. And this phenomenon arises, increasingly, with the potential to open new ways for the working class. This paper aims to contribute in practice to the development of this movement through the elaboration of legal analyzes wich can aid workers who have occupied or intend to occupy companies in crisis . Although we are aware that the role of legal institutions is not neutral and have a contradictory and classist character, it is still necessary that the legal struggles are fought, and, therefore, the working class needs progressive legal formulations. There are four central legal issues faced by CRW's: a) the legality of the strike occupancy; b) the need for recognition of workers' management in the insolvency and corporate recovery procedure; c ) the need, in the medium and long-term, of legal stabilization of the collective being, through the establishment of an appropriate legal form and d) the need, in general, of other specific public policies, especially those that provide access to credit. Considering this context, this paper has two specific focuses: first, develop a study on the constitutional bases that can be used to cope with all legal matters . And, second, to propose solutions to one of the thorniest issues: the legality of the active strike - one that occurs with occupancy to produce. In the first part, we conclude that the three constitutional principles that are fundamental to the legal issues that arise in these cases - the principle of the social function of property, the principle of the social value of work and free enterprise and the principle of right to work - have the purpose of uttering commands for legal agents to create laws, develop public policy, prohibit the performance of contrary acts and interpret the legal system to promote the development of recoveries. Then, we conclude that the sit-in strike - passive or active - will be legal if triggered within certain contexts and subject to certain conditions. The active strike, in particular (the one that has the intention of producing), will be lawful, from a confrontation with the principles of the Constitution to the Theory of Fundamental Rights, if triggered in response to an acute crisis in the company generated by mismanagement or accompanied by acts of corporate malfeasance, wich are acts that imply a serious breach of social responsibilities established by law for the controller of production assets.
\end{abstract}

Keywords: Workers production control. Companies Recoreved by Workers. Sit-down strike. Social function of property of production assets. 


\section{SUMÁRIO}

INTRODUÇÃO

1 A RECUPERAÇÃO DE EMPRESAS POR TRABALHADORES: UMA HISTÓRIA NÃO CONTADA

1.1 Controlar a produção: anseio revolucionário que nasceu com o capitalismo

1.2 Continuação de empresas via gestão operária: práxis provocadora

1.3 “Ocupar, Resistir, Produzir!”: a posição destacada da América Latina no movimento das ERTs

1.4 O MFO e a Fábrica Ocupada Flaskô: um olhar para além do capital

1.5 Relevância do estudo das experiências de recuperação: um novo caminho

2 O DIREITO NAS TOMADAS OPERÁRIAS: LEI E LUTA DE CLASSES 50

2.1 Direito, ideologia e dominação 52

2.2 Ainda precisamos conhecer os mecanismos jurídicos 56

3 MIRANDO AS QUESTÕES JURÍDICAS: SOLUÇÕES FAVORÁVEIS A PARTIR DA CONSTITUIÇÃO DE 88

3.1 Prólogo: opção metodológica alexyana e base sociológica marxista

3.2 Três suportes para todos os enfrentamentos: princípios constitucionais da função social da propriedade, do direito ao trabalho e do valor social do trabalho e da livre iniciativa

3.2.1 Conteúdo jurídico e abrangência dos três suportes constitucionais

3.2.2 Pós-positivismo e efetividade dos princípios constitucionais

3.2.3 Efeitos das normas-princípio: uma ordem constitucional das continuações operárias

3.2.4 Uma questão para os céticos: ERTs geram trabalho e renda?

3.3 Licitude da greve de ocupação

3.3.1 Ocupar para pressionar em greves: expressão da autotutela laboral

3.3.2 Ocupar para produzir: o papel decisivo da medida de ocupação nas recuperações operárias

3.3.3 A Constituição como parâmetro: análise à luz da Teoria dos Direitos Fundamentais 
4.1 O destaque argentino: reconhecimento sistemático na lei de falências 126

4.2 A oficialização da greve de ocupação no Uruguai 132

5 UM ENSAIO: GESTÃO OPERÁRIA E CONSTRUÇÃO DO SOCIALISMO 135

6 CONCLUSÕES 145

REFERENCIAS 


\section{INTRODUÇÃO}

No dia 09 de novembro de 2012, os trabalhadores da Flaskô, fábrica de galões plásticos da cidade de Sumaré, interior de São Paulo, tomaram conhecimento de mais uma boa notícia do universo das fábricas ocupadas: a companheira FasinPat Cooperativa, fábrica argentina do ramo de cerâmica, muito conhecida por seu antigo nome "Cerámicas Zanon", acabara de ser expropriada pelo estado em favor dos trabalhadores. O ato jurídico de expropriação definitiva foi o Decreto Ejecutivo $n^{o}$ 2977. Um "passo muito firme", que "descarta qualquer ameaça de despejo para os trabalhadores"1, segundo Marcelo Morales - trabalhador da FasinPat e Secretário Geral do Sindicato Ceramista de Neuquén (GIAMBELLUCA, 2012). Passo que só foi alcançado após um longo processo de luta. Agora, definitivamente, a fábrica é dos trabalhadores.

Tanto a Flaskô, brasileira, quanto a FaSinPat (sigla para "Fabrica Sin Patrón" ou "Fábrica Sem Patrão"), argentina, fazem parte de uma história que acompanhou, em paralelo, a história do sistema social capitalista: a história das empresas ocupadas e recuperadas por trabalhadores. São empresas que, negligenciadas por seus patrões durante um período de crise econômica, foram ocupadas por seus empregados, que passaram a geri-las. Um fenômeno que, em especial, emergiu com força no cenário latino-americano nas últimas três décadas e que, por suas características e seu virtual potencial revolucionário, mobilizou e mobiliza estudiosos, ativistas e trabalhadores.

É possível entender por que esse fenômeno existe e, desde o final do século $\mathrm{XX}$, se tornou estável e vem ganhando força crescente. A verdade é que o sistema social capitalista sempre impôs uma vida triste e difícil aos nove décimos da população que vivem afastados do controle do processo produtivo - a classe trabalhadora. No "rico" sudeste brasileiro, por exemplo, entre as 63 milhões de

\footnotetext{
${ }^{1}$ Tradução livre do original: "paso muy firme [...] descarta cualquier amenaza de desalojo para los trabajadores".
} 
pessoas em idade de trabalhar, nada menos que $40 \%$ (25 milhões) não têm ensino fundamental completo; são os subtrabalhadores que formam a enorme base da pirâmide de divisão cruel do trabalho do sistema. Enquanto isso, na outra ponta, apenas $11 \%$ (7 milhões) têm diploma de ensino superior. Nessa conjuntura, o privilégio de ter um trabalho formal - o que, de modo algum, significa ter uma vida digna - é garantido para apenas 21 milhões $(34 \%)^{2}$. Essa triste condição de vida infligida pelo modo de produção do século XVIII sempre levou (e sempre levará) a classe trabalhadora a procurar alternativas para superá-lo. E, após a derrocada das tentativas fracassadas do século XX, que se centraram na tentativa de tomada do poder estatal - por golpe ou por eleições - essa classe inicia o presente século XXI com os olhos voltados para a busca de novas alternativas de enfrentamento à barbárie.

O presente estudo trata, pela perspectiva dos recuperadores, de elaborar suportes para o enfrentamento de algumas das questões jurídicas que emergem desse fenômeno social atual e relevante, considerando os problemas apontados pelos integrantes de experiências brasileiras. A pesquisa foi realizada pelo estudo da bibliografia existente sobre o tema e, também, de textos institucionais, como decisões judiciais e pareceres oficiais ${ }^{3}$.

É uma problemática relevante, se temos em conta que os coletivos de trabalhadores brasileiros que, nos dias de hoje, resolvem assumir empresa falidas de seus patrões enfrentam um grande problema: a carência de respostas estáveis, favoráveis e eficazes às questões jurídicas que surgem no desenrolar de sua empreitada. Vemos, por exemplo, que o Poder Judiciário é indicado pelos trabalhadores como o agente externo que menos apoia os processos de recuperação operária de empresas, e cerca de $60 \%$ das recuperadas relata não ter recebido nem receber apoio do Estado para a recuperação e manutenção da empresa (HENRIQUES et al., 2013, p. 56 e 210).

Trata-se de um problema de grande relevância, tendo em visa que questões jurídicas se colocam ao longo de todo o processo de recuperação de empresas e são,

\footnotetext{
${ }^{2}$ Fontes: Censo IBGE Resultados Gerais da Amostra 2010 e GFIP 2011.

${ }^{3}$ Contamos com especial auxílio do advogado e militante Alexandre Mandl, assessor jurídico da fábrica Flaskô, que nos enviou material valioso relacionado ao processo de ocupação e continuação da fábrica (como, por exemplo, a íntegra da decisão do juiz da Vara da Fazenda Pública de Joinville/SC que decretou a intervenção na Cipla em 2007).
} 
muitas vezes, determinantes de seu êxito ou fracasso.

Em nosso estudo, identificamos que são quatro as problemáticas jurídicas centrais enfrentadas pelas empresas recuperadas: a) a licitude da greve de ocupação; b) a necessidade de reconhecimento da gestão operária no procedimento de falência e recuperação empresarial; c) a necessidade, em médio e longo prazo, de estabilização jurídica do ente coletivo, por meio da constituição de uma forma jurídica adequada e d) a carência, em geral, de outras políticas públicas específicas, especialmente as que possibilitem o acesso a crédito.

Considerando essa complexidade de problemas, para esta pesquisa selecionamos dois focos principais: em primeiro lugar, desenvolver um estudo acerca das bases constitucionais que podem ser utilizadas para o enfrentamento de todas as questões jurídicas. E, em segundo, propor solução a uma das questões mais espinhosas: a da licitude da greve ativa - aquela que se dá com ocupação para produzir.

Utilizaremos como apoio os caminhos já trilhados no Brasil e em outros países, especialmente nos vizinhos Argentina e Uruguai. E, a partir disso, proporemos soluções para a superação de tais questões, tanto no âmbito legislativo quanto no âmbito judicial.

A intenção é de que a análise aqui construída possa auxiliar coletivos operários (que tenham ocupado ou que se proponham a ocupar empresas em crise), fornecendo informações e fundamentos jurídicos para suas ações e seus requerimentos perante os órgãos estatais.

Tem sido recorrente, nessas experiências de ocupação, que questões legais meramente formais ou sem relevância jurídico-social se transformem em grandes entraves à realização de objetivos maiores: a manutenção da fonte de renda dos trabalhadores e de suas famílias e a continuação da produção da empresa. Esse posicionamento das instâncias do direito é inaceitável, mesmo do ponto de vista do discurso jurídico hegemônico, de matriz ideológica liberal. Cientes dos limites de atuação das instituições jurídicas e de seu papel conservador no modo de produção capitalista, entendemos que análises como a deste trabalho podem contribuir, nos momentos concretos, para reduzir o tamanho desse obstáculo que se coloca à realização da gestão operária. 


\section{A RECUPERAÇÃO DE EMPRESAS POR TRABALHADORES: UMA HISTÓRIA NÃO CONTADA}

Às 17 horas, cinquenta costureiras de idade madura, com penteados nada anarquistas, sapatos confortáveis e uniformes azuis de trabalho, caminharam até a barreira negra de policiais. Alguém empurrou, a barreira cedeu, e as mulheres da Brukman, desarmadas e de braços atados, entraram lentamente.

21 de abril de 2003, Argentina, a retomada da Brukman (KLEIN, 2003, p. 13)

No dia 12 de fevereiro deste ano (2013), numa Grécia em crise, uma fábrica denominada Vio.Me., que convulsionava desde 2010, retomou sua produção sob controle dos trabalhadores (OPEN INITIATIVE OF SOLIDARITY AND SUPPORT, 2013). Em meio a um contexto nacional caótico, com $27 \%$ da população desempregada (60\%, se considerados apenas os jovens), a retomada da produção de uma fábrica desse modo nada convencional é um fato relevante, digno de notícia. Sem dúvidas, algo que cada um dos seis bilhões de trabalhadores do mundo gostaria de saber: "se meu patrão falir, existe a opção de continuar a empresa com meus companheiros". A verdade, entretanto, é que poucos de nós tiveram e terão a oportunidade de conhecê-lo. Com a exceção de alguns poucos jornais virtuais ou blogs alternativos (como, por exemplo, o portal brasileiro de tendência libertária passapalavra.com), a mídia nacional - e também a internacional - não dedicou espaço algum ao fato.

Como sempre.

De fato, a Vio.Me. não foi a única ERT - Empresa Recuperada por Trabalhadores - no ano de 2013. E a Grécia não foi o único país a presenciar um fenômeno como esse. Há uma vasta história, interessante e instigante, da ocupação e recuperação de fábricas por trabalhadores. Uma história que passa pelos precoces movimentos operários ingleses da primeira metade do século XIX (aquele contexto sociopolítico efervescente de cinco décadas que fez nascerem personalidades como Owen, Fourier, Proudhon, Bakunin, Marx e Engels, os primeiros críticos do 
capitalismo da história), pela paradigmática ocupação da fábrica de relógios Lip Watch, em 1973, na França, pela explosão de ocupações nos países da América Latina na primeira década do século $\mathrm{XX}$, e pelos resultados atuais da grave crise econômica mundial que estourou em 2008, com novas ocupações no Brasil e, também, em países como Grécia, Espanha e Estados Unidos.

Este capítulo se destina a contar um pouco desta história, contribuindo para romper o silêncio. $\mathrm{Na}$ apresentação, pretendemos esclarecer sua relação com o funcionamento real do modo de produção capitalista e, em seguida, dar especial atenção para a América Latina e para um específico e importante caso brasileiro, o das fábricas Flaskô, Cipla e Interfibra, fundadoras do Movimento das Fábricas Ocupadas.

\subsection{Controlar a produção: anseio revolucionário que nasceu com o capitalismo}

Nós decidimos fazer uma cooperativa porque estávamos cansados de ter nossas vidas nas mãos de outra pessoa.

10 de maio de 2013, fala de trabalhador à imprensa sobre a inauguração da New Era Windows Cooperative, em Chicago-EUA (FLANDERS, 2013)

No ano de 1811, um grupo de operários têxteis fez sua fama em toda a Inglaterra por ter realizado um ato de destruição dos teares mecânicos da oficina em que trabalhavam, em uma pequena cidade próxima de Londres. Seu raciocínio, provavelmente, foi simples: "antes, estas máquinas não existiam, nós trabalhávamos com tranquilidade e todos tinham trabalho; depois que estes teares chegaram, eles nos obrigam a trabalhar muito mais rápido, nosso trabalho é fragmentado e sem sentido, e, por sua causa, vários perderam seus empregos; então, este tear é a causa da nossa desgraça". Esse gesto de revolta não apenas ficou conhecido como foi 
imitado por trabalhadores em várias cidades inglesas nos anos de 1811 e 1812 . Foi o primeiro movimento de revolta operária da história do sistema social capitalista, que ficou conhecido como luddismo, por referência a Nedd Ludd, apontado como o líder do movimento (mas que, talvez, tenha sido apenas um personagem criado para despistar a polícia burguesa). Em resposta, pela primeira vez na história um parlamento editou uma lei de repressão à classe proletária: pena de morte para os que destruíssem as máquinas de seus patrões (BORGES, 2006, p. 4).

Esse foi, entretanto, apenas o início imaturo dos atos coletivos de luta da classe operária contra a dominação e a opressão impostas, em benefício dos empregadores e sob sua coordenação, pelo modo de produção capitalista. Nascia, também, ali, o movimento sindical: a organização racional da classe operária com o objetivo de utilizar sua força coletiva para impor, principalmente por meio de greves, reivindicações de melhora de salários e condições de trabalho à burguesia (SINGER, 2012, p. 83), e que se transformou, como sabemos, na forma típica e difundida de ação da classe trabalhadora na vida do sistema social capitalista. Mas, além do sindicalismo, esses anos viram germinar, também, outro movimento da classe trabalhadora. Movimento que, exatamente por suas características, nunca teve a difusão do sindicalismo, mas, também, nunca deixou de se fazer presente: o anseio por controlar o processo produtivo.

O fenômeno da ocupação e da recuperação de empresas é parte deste segundo movimento.

Esse anseio, que se explica pela postura de recusar tanto o caminho da destruição das máquinas (o que expressava um desejo de retorno ao passado), quanto o da negociação eterna com o patronato (o que significa uma acomodação à condição subalterna na produção), teve sua primeira expressão prática nas iniciativas cooperativistas.

O início do cooperativismo foi influenciado pelas ideias de Robert Owen, o galês que, poucos anos depois, foi classificado por Marx e Engels como socialista utópico. Mas a real contribuição de Owen ao anseio revolucionário do movimento operário não se deu nas primeiras propostas e tentativas de criação de aldeias cooperativas, coordenadas verticalmente por Owen e outros filantropos da elite inspirados nele (BERNARDO, 1999, p. 33-4). Deu-se em sua atuação (muito menos 
comentada, diga-se) junto ao movimento operário depois de seu retorno dos Estados Unidos da América, após o novo fracasso da implantação do projeto de aldeia cooperativa no "novo mundo" (SINGER, 2002, p. 24-35).

À época, as jovens organizações sindicais haviam visto no projeto cooperativista - em expansão - uma possível arma de luta, talvez ainda mais revolucionária, contra a classe capitalista. A ideia era simples, ao menos no papel: tomar a produção e substituir os capitalistas. "Tornou-se comum que grevistas, em ramos que podiam ser operados sem muita máquina, em vez de cruzar os braços, se lançassem em competição com seus empregadores à base de planos de produção cooperativa" (COLE apud SINGER, 2002, p. 29). E Owen, provavelmente tendo concluído que apenas os trabalhadores - e não a elite - estariam realmente interessados na implantação de uma forma de produção igualitária, aliou-se a elas.

Como narra o economista brasileiro Paul Singer, em seu Introdução à Economia Solidária, "a luta dos sindicatos contra os capitalistas, utilizando as cooperativas operárias como armas para disputar-lhes o mercado, estava chegando ao auge em 1833, quando Owen reapareceu, assumindo sua liderança” (2002, p. 32).

A primeira iniciativa foi do Sindicato dos Trabalhadores em Construção, em 1833. Deu-se em meio a um violento ataque classista por parte dos empreiteiros em reação à organização dos trabalhadores: em junho, eles organizaram um lockout que implica no não pagamento de salários - e começaram a demitir todos os trabalhadores associados ao sindicato. $\mathrm{O}$ sindicato aprovou, numa reunião de setembro, a proposta de criar a Grande Guilda Nacional dos Construtores "para suplantar os empreiteiros privados e tomar toda a indústria em suas próprias mãos, reorganizando-a sob a forma de uma grande cooperativa nacional de construção" (SINGER, 2002, p. 32). No mesmo ano, em outubro, outros sindicatos aprovaram o projeto de criação da Grande Guilda Nacional Moral das Classes Produtivas do Reino Unido (GUNM), que "tinha por objetivo tomar toda a indústria do país do mesmo modo que os construtores se propunham a tomar a indústria de construção" (SINGER, 2002, p. 33). As propostas, entretanto, acirraram o conflito, que tomou toda a Inglaterra. Os gestores capitalistas se viram, já nos primeiros passos de sua história de dominação, forçados a lançar mão de suas armas mais poderosas para a luta de classes: o domínio da produção e o domínio do aparato estatal. Industriais de 
diversos setores realizaram lockouts e demitiram sindicalizados, tirando dos trabalhadores seu meio de subsistência e, ao mesmo tempo, forçando-os a lembrarem-se amargamente de sua dependência material. Enquanto isso, o poder público perseguiu e prendeu lideranças sindicais (SINGER, 2002, p. 34). Com isso, venceram. Cole conta que

[...] em face da crescente militância dos empregadores e da declarada hostilidade do governo, os sindicalistas em muitas áreas começaram a perder o ânimo. Owen e seus discípulos puseram-se à frente da demanda pela libertação dos trabalhadores de Dorchester e entraram na GUNM em bloco, na esperança de salvar a situação. Mas uma greve sem sucesso dos alfaiates de Londres - que em seu decorrer cobriram Londres de cartazes anunciando que estavam partindo em bloco para a Produção Cooperativa - piorou seriamente a situação; e os empregadores de Yorkshire, retomando a ofensiva do ano anterior, conseguiram em maio e junho quebrar o poder do Sindicato de Leeds. O Sindicato dos Trabalhadores em Construção também estava ruindo face a repetidos ataques. (...) $\mathrm{E}$ uma após a outra, as associações de ofício foram deixando o sindicato, que no fim de 1834 se extinguiu. As oficinas cooperativas em Derby tiveram de fechar, e os homens foram forçados a voltar ao trabalho nas condições impostas pelos empregadores. O Sindicato dos Oleiros, que montou uma olaria cooperativa em junho de 1834 , teve de abandoná-la seis meses depois. A grande aventura sindical estava chegando a um fim sem glória (apud SINGER, 2002, p. 34-35).

Esta, segundo Singer, é a origem histórica da economia solidária - uma das expressões utilizadas atualmente para identificar o que estamos chamando genericamente de movimento de anseio da classe trabalhadora por controlar a produção. Fase desse movimento que, segundo Singer, poderia ser chamada de “cooperativismo revolucionário", que "jamais se repetiu de forma tão nítida" e "tornou evidente a ligação essencial da economia solidária com a crítica operária e socialista ao capitalismo" (2002, p. 35).

Desde este início, o anseio revolucionário nunca se apagou e assumiu diversas formas.

Poucas décadas depois, recebeu a poderosa e histórica contribuição de Karl Marx, o grande explicador e crítico do sistema social capitalista. Marx e Engels, assim como seus contemporâneos Proudhon e Bakunin, miraram suas teorias para, entre outros, o grande objetivo de controle operário da produção (BOURDET \& GUILLERM, 1976, p. 61-7). Entretanto, Marx não teve ideias muito precisas sobre essa questão, ligada não à crítica do capital, mas ao caminho de construção de uma 
sociedade para além dele. Como explicam Yvon Bourdet e Alain Guillerm, "tendo feito uma crítica do 'socialismo utópico', [Marx] inclinou-se a pensar que bastaria inicialmente fazer a revolução (expropriar os possuidores dos meios de produção) e, quanto ao resto, confiar na espontaneidade das massas, que criariam as organizações institucionais adequadas para realizar a comunidade humana" (1976, p. 62).

Mas isso revelou certa carência de sua parte, gerando fórmulas estatistas em suas primeiras obras. Assim é que, no Manifesto Comunista (1847), Marx escreveu: 'O proletariado utilizará sua supremacia política para arrancar pouco a pouco todo o capital à burguesia, para centralizar todos os instrumentos de produção entre as mãos do Estado, isto é, do proletariado organizado em classe dominante' (1976, p. 62).

Entretanto, em obras posteriores posicionou-se de modo diferente, indo um pouco além. N'O Capital, sua grande obra, criou a fórmula "do autogoverno dos produtores associados" e afirmou, sobre o movimento cooperativo, que "as cooperativas obreiras representam, no interior do antigo sistema, a primeira brecha nele feita” (BOURDET \& GUILLERM, 1976, p. 28 e 62). E, cinco anos mais tarde, durante a Comuna de Paris, chegou a dizer na obra A Guerra Civil na França que

Se a produção cooperativa não deve continuar a ser um engodo e uma armadilha; se deve desapontar o sistema capitalista; se o conjunto das associações cooperativas deve regular a produção nacional segundo um plano comum [...] que seria isto [...] senão o comunismo, ao menos um muito provável comunismo? (apud BOURDET \& GUILLERM, 1976, p. 29, grifos dos autores).

Marx, portanto, em seus últimos escritos, mostrou-se atento à possibilidade de construir a revolução socialista pelo controle da produção em precedência ao controle do Estado, fato que foi absolutamente ignorado por Lênin e o Partido Bolchevique. E talvez seja, ainda hoje, pela maioria daqueles que desejam a superação do capitalismo.

A batalha pelo controle do processo produtivo continuou, e teve muitos episódios importantes. Do século XIX à queda do muro de Berlim, designadamente, foram três. A curta experiência da Comuna de Paris, quando, por dois meses e meio, em 1871, o proletariado tomou a capital francesa e ocupou as fábricas, procurando fazê-las funcionarem democraticamente (BOURDET \& GUILLERM, 1976, p. 1104). A Revolução Russa de 1917 e o fenômeno dos sovietes, espécie de conselhos operários nascidos espontaneamente nas fábricas e que deram o suporte político à tomada do governo pelo partido bolchevique (BOURDET \& GUILLERM, 1976, p. 
115-7). E a tentativa da Iugoslávia de Tito, entre 1950 e 1965, após o rompimento com Stalin, de implantar, pela via estatal, um regime nacional de autogestão na produção (BOURDET \& GUILLERM, 1976, p. 131-44).

Após esse período, no final do "breve século XX" (HOBSBAWN, 1995), transformações históricas de grande porte influenciaram uma mudança definitiva no rumo do movimento.

A primeira transformação foi a realização do projeto neoliberal no mundo global capitalista. Com ele, como narra Singer,

[...] a partir da segunda metade dos anos 70, [...] o desemprego em massa começou o seu retorno. Nas décadas seguintes, grande parte da produção industrial mundial foi transferida para países em que as conquistas do movimento operário nunca se realizaram. $\mathrm{O}$ que provocou a desindustrialização dos países centrais e mesmo de países semi-desenvolvidos como o Brasil, eliminando milhões de postos de trabalho formal. Ter um emprego em que seja possível gozar os direitos legais e fazer carreira passou a ser privilégio de uma minoria. Os sindicatos se debilitaram pela perda de grande parte de sua base social e consequentemente de sua capacidade de ampliar os direitos dos assalariados. Na realidade, pela pressão do desemprego em massa, a situação dos trabalhadores que continuaram empregados também piorou: muitos foram obrigados a aceitar a 'flexibilização' de seus direitos e a redução de salários diretos e indiretos. Sobretudo a instabilidade no emprego se agravou, e a competição entre os trabalhadores dentro das empresas para escapar da demissão deve ter se intensificado (2002, p. 110).

A segunda foi o fim definitivo da experiência de socialismo estatal da URSS. A “crise dos Estados do 'socialismo realmente existente' da Europa Oriental, que estourou em 1985, com a Perestroika e a Glasnost na União Soviética, e culminou em 1991 com a sua dissolução" (SINGER, 2002, p. 111). Com ela,

Subitamente ficou claro para milhões de socialistas e comunistas de todo o mundo que o planejamento central da economia do país, imposto por uma pseudo- ‘ditadura do proletariado', não constrói uma sociedade que tenha qualquer semelhança com o que se entendeu que fosse socialismo ou comunismo. Esta nova consciência levou indubitavelmente muitos a se reconciliar com o capitalismo, mas muitos outros sentem-se desafiados a buscar um novo modelo de sociedade que supere o capitalismo, em termos de igualdade, liberdade e segurança para todos os cidadãos (SINGER, 2002, p. 111).

E a terceira,

[...] o semifracasso dos governos e partidos social-democratas, 
principalmente na Europa mas também, mutatis mutandi, na América Latina. Mesmo vencendo eleições e exercendo o poder governamental, os social-democratas não conseguiram muito mais do que atenuar os excessos do neoliberalismo e preservar mal as instituições básicas do Estado de bem-estar social. Não tentaram reverter a privatização dos serviços públicos nem a desregulamentação das finanças mundiais, submetendo as economias nacionais, sobretudo na periferia, aos ditames do grande capital financeiro global (SINGER, 2002, p. 111-2).

Com essas três transformações, uma hipótese perturbadora se colocou com força aos olhos da esquerda mundial: o caminho da superação do capitalismo não é a tomada do poder estatal. Nem pela força, nem por eleições.

\begin{abstract}
As duas transformações subverteram a concepção (até então amplamente dominante) de que o caminho da emancipação passa necessariamente pela tomada do poder de Estado. O foco dos movimentos emancipatórios voltou-se então cada vez mais para a sociedade civil: multiplicaram-se as organizações nãogovernamentais (ONGs) e movimentos de libertação cuja atuação visa preservar o meio ambiente natural, a biodiversidade, o resgate da dignidade humana de grupos oprimidos e discriminados (de que o zapatismo mexicano talvez seja o paradigma) e a promoção de comunidades que por sua própria iniciativa e empenho melhoram suas condições de vida, renovam suas tradições culturais etc. (SINGER, 2002, p. 112).
\end{abstract}

Concordamos com o professor português João Bernardo quando defende que se encerrou neste momento, pelo colapso da URSS e, também, pela crise de legitimidade dos sindicados nas décadas de 60 e 70, um ciclo histórico (1999, p. 3342). O ciclo histórico que começou com as experiências de Owen, em 1825, e terminou apenas no fim do século XX, e se caracteriza pela não consideração, pelos desejosos da superação do capitalismo, da "diferença prática entre relações sociais de produção e relações jurídicas de propriedade" (1999, p. 34).

Encerrado este ciclo histórico, entretanto, iniciou-se outro, no qual o conflito que se eleva é o existente entre duas formas de organização, ou de relações sociais de produção: a auto-organização e a hetero-organização. Um "novo grande ciclo [...] em que o tema básico é a gestão e o controle" (BERNARDO, 1999, p. 42).

Confirmando essa tese, vemos que, da segunda metade do século XX até hoje, o projeto de revolução pela tomada de poder estatal apenas enfraqueceu (apesar de ainda ter adeptos; no Brasil, por exemplo, esta é, declaradamente, a posição do Partido Socialista dos Trabalhadores Unidos - PSTU, um importante encabeçador de mobilizações à esquerda). E, por outro lado, cresceu o interesse pelas tentativas de 
controle direto da produção, de modo que inúmeras experiências nesse sentido surgiram em todo o mundo.

O caso cooperativista mais famoso - e, talvez, de maior sucesso - é o do complexo cooperativo de Mondragón, na Espanha. Trata-se de um complexo com mais de 100 cooperativas, com notável êxito econômico, que já dura mais de cinquenta anos (SINGER, 2002, p. 98-105) (SANTOS, 2012, p 37-41). Outros casos notáveis citados pelos pesquisadores da área são os antigos Kibbutzim, em Israel (SINGER, 1999, p. 26), o Beedi, na Índia, e o Cruz Azul e Pascual, no México (HERNANDEZ, 2012, p. 187). E no Brasil, por fim, as experiências cooperativas do MST (Movimento dos Trabalhadores Sem Terra) (SINGER, 2012, p. 103-7) e o complexo da Usina Catende, que cobre cinco municípios em Pernambuco e ocupa atualmente pelo menos mil trabalhadores (SINGER, 2012, p. 91) (HENRIQUES et al., p. 244).

Expusemos, até agora, as linhas gerais deste movimento histórico de anseio da classe trabalhadora por controlar a produção, sem mencionar, intencionalmente, sua dimensão da recuperação de empresas pelos trabalhadores e dando ênfase ao seu aspecto cooperativista. Fazemos assim porque a história da recuperação de empresas por trabalhadores tem características que justificam sua narrativa à parte.

Esta dissertação trata, como se observa no título, apenas do fenômeno das Empresas Recuperadas por Trabalhadores (ERTs). Há uma razão para isso: acreditamos, ao lado de pesquisadores entusiastas da área, como os brasileiros Henrique Tahan Novaes e Renato Dagnino, que ele é o "movimento com maior potencial de radicalização e de geração de transformações significativas do modo de produção capitalista" (DAGNINO \& NOVAES, 2013, p. 18).

Não é assim com o movimento cooperativista, que é, em certo sentido, contraditório. Pela amplitude e heterogeneidade de tudo o que se denominou "cooperativismo" até hoje, pode-se dizer, sem receio, que ele pode ser captado com mãos cheias tanto por conservadores do modo de produção capitalista quanto por desejosos de revolucioná-lo. Diversos fatos de nossa história nos dão indícios disso.

As contradições já começam na origem do movimento. Apesar da explosão revolucionária inicial do movimento cooperativo nas mãos do movimento sindical no início do século XIX, a idealização de primeiras cooperativas foi feita por Fourier e 
Owen, filhos da burguesia; e, não bastasse, proposta inicialmente por eles à elite, e não à classe trabalhadora. Outro fato ainda mais perturbador: no decorrer da história, inúmeros governos reconhecidamente autoritários o incentivaram e realizaram ações visando implantá-lo: o estado imperialista de Napoleão III, que, "em 1867, fez votar o estatuto legal das cooperativas operárias de produção" (BOURDET \& GUILLERM, 1976, p. 61), o estado fascista de Mussolini, cujo partido, em 1921, colocou o objetivo de desenvolver cooperativas entre os pilares de seu programa de governo; e, no Brasil, o Estado Novo de Getúlio Vargas, que editou vasta legislação com o objetivo declarado de incentivar o desenvolvimento do cooperativismo (Decretos-Leis n ${ }^{\circ}$ s. 22.239/1932, 581/1938, 926/1938, 1.836/1939, 6.980/1941, e 5.154/1942). Por último, um fenômeno contemporâneo: o fato conhecido de que muitos dos empreendimentos que se autodenominam cooperativas, hoje, nada têm de questionador do sistema de organização do trabalho capitalista. E se enquadram aí tanto as unidades produtivas ajustadas à lei cooperativista, mas absolutamente sem características de organização que a diferenciem de empresas capitalistas (como, por exemplo, as "cooperativas de médicos", onde todos os trabalhadores não médicos, que são a maioria, não são cooperados, mas empregados); quanto as empresas que executam atividades de baixo valor agregado em regime de terceirização, que são criadas por gestores capitalistas e, fraudulentamente, registradas como cooperativas (um mecanismo de precarização do trabalho típico de nossa época) ${ }^{4}$; além das unidades produtivas criadas pela parcela mais pobre da classe trabalhadora, em geral com assistência intelectual externa (proveniente, por exemplo, das incubadoras universitárias), para executar atividades também de baixo valor agregado que o mercado capitalista não teve interesse em agregar (é o caso, atual e global, das cooperativas de catadores de lixo $)^{5}$.

Por tudo isso, podemos concluir que o cooperativismo, dependendo da forma que assume, pode se adaptar perfeitamente à estrutura desigual do sistema e assumir um caráter bastante conservador. Por essas razões, atualmente, qualquer uso desse conceito deve ser precedido de uma explicação clara por parte do enunciador, para se saiba exatamente a que ele se refere.

Essa confusão não acontece, entretanto, com o fenômeno das empresas

\footnotetext{
${ }^{4}$ Para uma perspectiva jurídica crítica acerca dessas últimas, veja-se Feliciano (2009).

5 Sobre isso, resumidamente, Dagnino e Novaes (2013, p. 19-20). E, também, a partir de uma perspectiva argentina, Ruggeri (2012, p. 23-5).
} 
recuperadas por trabalhadores. E agora voltamos a ele, para não mais sair.

\subsection{Continuação de empresas via gestão operária: práxis provocadora}

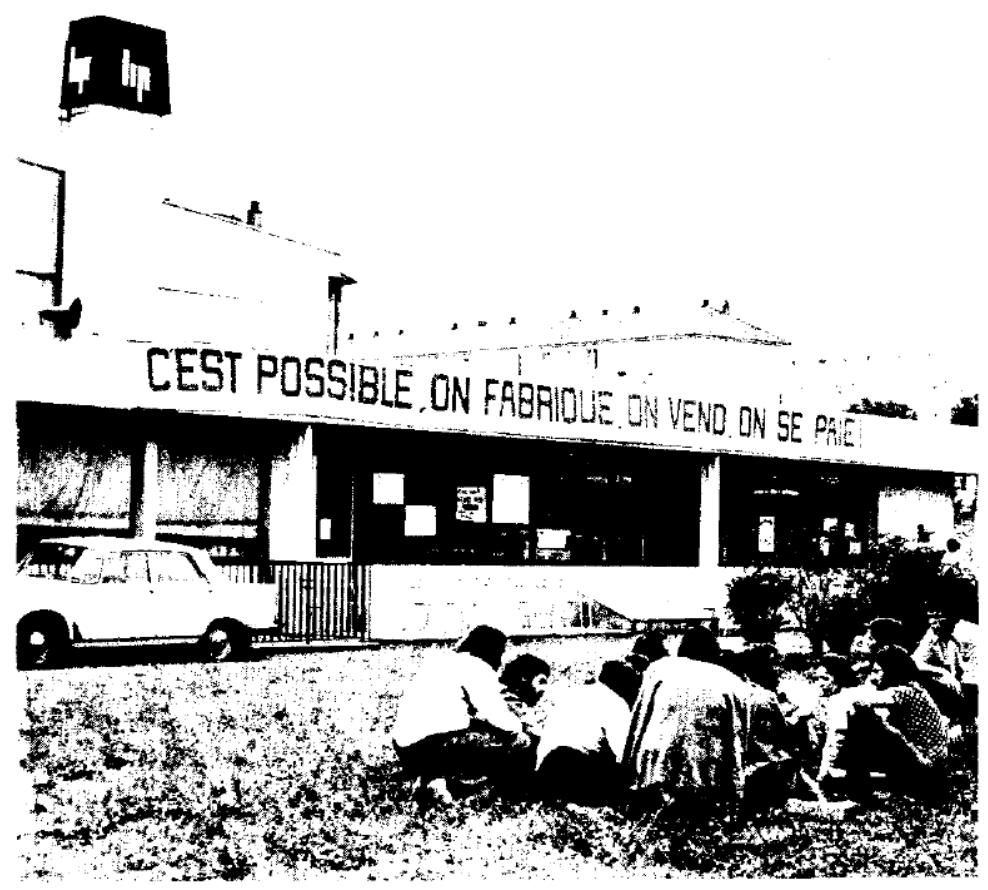

É possível: nós produzimos, nós vendemos, nós nos pagamos.

Figura 1. Junho de 1973, porta da fábrica de relógios Lip, em Besancón-França (RADICAL AMERICA, 1973, p. 3)

A classe empresarial capitalista, interessada na conservação do sistema social que a privilegia, não vê, em geral, o fenômeno da ocupação e da continuação operária de empresas com bons olhos. Como afirmam Dagnino e Novaes, comparando com os dois movimentos sociais mais ativos no país hoje - o dos trabalhadores rurais sem terra (que, entre várias organizações, tem no MST sua maior expressão) e o dos trabalhadores urbanos sem teto -,

o movimento das ERTs encontra por parte da classe dominante um tipo de oposição bastante diferente daquele dos seus dois congêneres. Sem aprofundar no tema, basta considerar que as 
condições sob as quais pode ocorrer a recuperação de uma fábrica pelos seus trabalhadores, e as ações que a possibilitam, que usualmente se iniciam com sua ocupação, são vistas como ainda mais culturalmente ilegítimas e 'ilegais' do que aquelas que resultam da luta pela terra ou pela moradia. Além do que, e isso contribui ainda mais para que possam ser frequentemente reprimidas, elas ocorrem num espaço autocontido, isolado do espaço social e, por isso, pouco percebido pela sociedade (2013, p. $18)$.

Não é por acaso. O fato de um membro da classe trabalhadora, tomado por um ímpeto de coragem e por um sentimento de coletividade, lançar-se à tentativa de assumir uma empresa com seus companheiros é, por si só, provocador do sistema. Isso porque a ideologia desse sistema lhe convence de que ele não é capaz, pois essa atividade intelectual é para poucos. Assim, a continuação produtiva de empresas por trabalhadores acaba sempre expondo a xeque a fonte real de poder do capitalista: o domínio que tem do processo produtivo.

Isso pode ser visto na história desse movimento.

A prática esparsa de ocupar fábricas com a intenção de assumir a condução da produção surgiu com o nascimento do movimento operário, logo após a consolidação do sistema social capitalista, no século XIX.

É possível afirmar isso não por nenhum movimento organizado conhecido, mas pelas menções esparsas de observadores e críticos do sistema. As primeiras ocupações com continuação, ao que tudo indica, ocorreram no momento da história da Inglaterra a que já nos referimos: a década de 1830, quando o movimento sindical inglês tinha em sua pauta o "cooperativismo revolucionário" e enfrentava a burguesia com a ameaça de substituí-la (SINGER, 2002, p. 32-5). Algumas décadas depois, o companheiro intelectual de Marx, Friedrich Engels, quando montava o terceiro volume d'O Capital, introduziu uma nota fazendo referência a um caso de recuperação. Escreveu: "em um caso de meu conhecimento, um fabricante falido após a Crise de 1868 tornou-se empregado assalariado de seus próprios extrabalhadores. A fábrica depois da bancarrota foi recuperada por uma cooperativa de trabalho e o antigo proprietário foi empregado pela cooperativa como dirigente" (apud HENRIQUES et al., p. 10). Na mesma época, outro autor clássico do século XIX que, apesar de liberal, fez referência entusiasmada a experiências de recuperação de empresas por trabalhadores que aconteciam em sua época na França e Inglaterra, é John Stuart Mill, na sexta edição, de 1865, da obra Princípios de 
economia política (SINGER, 1999, p. 25).

Passando para o século XX, mais especificamente no primeiro quarto, uma onda de ocupações com continuação da produção ocorreu na Itália. O movimento operário italiano se viu influenciado pela vigorosa difusão de ideias socialistas e anarquistas que marcou a época, e, conjuntamente, pelo calor recente da Revolução Russa. Assim, no ano de 1920, o movimento ocupou diversas fábricas do triângulo industrial Milão-Turim-Gênova, começando pela montadora de automóveis Fiat, e colocou-as para funcionar sob a direção de conselhos operários. As ocupações duraram alguns meses. A reação a essa efervescência revolucionária é conhecida: dois anos depois, com o apoio maciço da classe média, ascendia ao governo o Partido Nacional Fascista, liderado por Benito Mussolini (RICCI, 2010).

Essas são as linhas gerais do movimento de recuperação operária de empresas até 1973, ano em que um caso paradigmático, juntamente com seu contexto específico, alterou seu rumo para sempre. Acreditamos que muitos outros casos ocorreram neste período de quase dois séculos. No entanto, como esses citados, tiveram existência curta (poucos meses, ou, até mesmo, dias), e ocorreram de maneira esparsa e isolada.

É possível entender porque, mesmo em manifestações instáveis e isoladas, a ideia de assumir a produção surgiu com o capitalismo e nunca o abandonou. A verdade é que esse anseio é uma pedra entalada na garganta de cada trabalhador. $\mathrm{O}$ sistema social capitalista funciona, desde seu início, com uma divisão muito clara dentro de cada fábrica: no topo, os patrões, que têm desenvolvidas habilidades necessárias para dirigir o negócio; abaixo, os peões, que não têm essas habilidades intelectuais desenvolvidas e acatam ordens para colocar as mãos na massa e fazer funcionar a produção. Foi assim na primeira fábrica montada, e é assim em cada fábrica e em cada local de trabalho existente no mundo capitalista atual. E, como condição para manter esta situação, funciona um gigantesco e profundo, mas silencioso, esforço para impedir que uma porção significativa dos membros da classe trabalhadora tenha acesso à aprendizagem das habilidades intelectuais necessárias para gerir um negócio; este é, talvez, o maior foco das ações da classe capitalista para manter sua dominação, desde sua ascensão ao poder. A verdade, entretanto, é que cada empregado sabe que poderia ser igual ao seu patrão. Cada empregado, no 
fundo, sabe disso: poderia, se tivesse o mesmo trajeto de vida, ter as habilidades intelectuais para gerir um negócio ou um local de trabalho. O problema é que ter ciência disso é perturbador. A condição de subordinado na produção não é confortável, não é satisfatória, para ninguém, pois a opressão e a alienação são sentidas, e amarguram. E, por isso, imaginar que poderia ser diferente, que não é uma condição necessária, é perturbador demais. Então, há inúmeros mecanismos destinados a fazer a classe trabalhadora se desviar desses pensamentos incômodos, e viver em paz com sua condição (dentre eles, a religião, que usa a eficiente explicação de que a condição de cada indivíduo é vontade de um ente mais poderoso e mais sábio e, portanto, não deve ser questionada). Mas nem sempre esses mecanismos funcionam. Às vezes, pela influência de determinadas condições (o medo da fome e a desconfiança da ideologia, em especial), o trabalhador se dispõe a romper esta barreira. Esses momentos sempre aconteceram na vida do sistema social capitalista, são inerentes a ele, com suas crises estruturais e oscilações de hegemonia pela dialética da luta de classes. Quando coincide de se cruzarem, nos caminhos da história, uma crise na empresa, com atraso de salários e ameaça de demissões, com um desses momentos de vontade de rompimento, voilà: temos a ocupação com intenção de continuar a produção. É possível entender, portanto, por que a ocupação de fábricas sempre ocorreu.

Retomando nosso curso, foi em 1973 que o movimento de recuperação de fábricas deixou para trás, para sempre, sua característica de descontinuidade. A experiência que protagonizou essa mudança foi a ocupação da fábrica de relógios Lip, em Besancón, França. Esse caso paradigmático, juntamente com seu contexto, é apontado por João Bernardo como um ponto de cisão que representou o encerramento de um ciclo histórico e o início de outro (1999, p. 40). Encerrou-se o ciclo histórico da propriedade e iniciou-se o da gestão.

A Lip era a maior e mais prestigiada fábrica de relógios da França, com 1.300 funcionários. Num processo construído por lutas coletivas ao longo dos anos, seus trabalhadores haviam conquistado uma organização sofisticada, com um comitê operário que representava todos os integrantes da planta, e uma maioria associada a uma das duas maiores centrais sindicais francesas (a CGT, Confederação Geral do Trabalho, e a CFDT, Confederação Democrática Francesa do Trabalho). Por consequência da organização, que lhes dava maior poder de barganha nas 
negociações coletivas, tinham salários ligeiramente maiores que os pagos em outras fábricas, e, até 1968, haviam angariado diversas conquistas trabalhistas, como um plano de aposentadoria e uma estrutura de evolução salarial (RADICAL AMERICA, 1973, p. 2).

A partir de 1969, entretanto, a empresa começou a dar sinais de crise. E, logo no início do próximo ano, após as vendas de natal, os administradores anunciaram um corte de 200 trabalhadores. Foi quando o conflito começou. Entre 1970 e 1973, trabalhadores e gerentes protagonizaram uma batalha na fábrica, uma batalha que, diferentemente de todas as outras, colocou em questão quem a controlava de fato. Após esse primeiro anúncio, "reuniões dos trabalhadores na fábrica e ameaças de iniciar uma greve forçaram a gerência a acabar com a ameaça de demissões". Os trabalhadores, extremamente unidos e organizados, e utilizando-se de um sistema sofisticado de comunicação interna e de formas de luta criativas, rejeitavam coletivamente cada anúncio de corte dos patrões; e, ao mesmo tempo, iam além, reivindicando melhoras que atingiam a todos (o que garantia o apoio geral, mesmo que as demissões atingissem só alguns). Com sua mobilização, a organização operária foi angariando não apenas o apoio de cada trabalhador da fábrica, mas, também, de outras fábricas, da comunidade, das centrais sindicais, e, por fim, de toda a classe trabalhadora francesa e internacional. E, nesses três anos, os trabalhadores venceram todas as batalhas. Até junho de 1973, apesar das inúmeras tentativas pela gerência, não houve nenhum corte de direitos, nenhuma demissão, mesmo diante das dificuldades financeiras da empresa. Os trabalhadores mostraram à gerência que controlavam as decisões sobre demissão na fábrica (MAI, 1973, p. 4-10).

Entretanto, a crise chegou ao seu auge em meados de 1973. Mesmo sem demissões, a fábrica estava parando por falta de trabalho. Como explicou um trabalhador da Lip em uma entrevista, "No começo de 1973 havia cada vez menos trabalho para ser feito em determinados setores [...]. Áreas inteiras da fábrica foram deixadas sem nenhum trabalho por várias semanas" ${ }^{6}$. Os trabalhadores estavam com receio de não receberem os próximos salários. Foi então que, em 12 de junho de 1973, após confirmarem que os gerentes planejavam realizar muitas demissões ou, até mesmo, fechar a fábrica, os trabalhadores ocuparam o local da reunião de

\footnotetext{
${ }^{6}$ Tradução livre de: "In the beginning of 1973 there was less and less work to be done in certain shops $[\ldots]$. Entire areas of the factory were left with no work at all for several weeks".
} 
gerência. E, a partir deste dia, tomaram o controle da fábrica, abandonada pela gerência. Também neste dia, um grupo deles, sem anunciar seu intento, foi até o estoque da fábrica e arrebatou todos os 65 mil relógios que lá estavam, visando utilizá-los como garantia de pagamento dos salários de junho. A apreensão, quando foi revelada aos demais trabalhadores em assembleia, recebeu um apoio maciço (MAI, 1973, p. 8-11).

Três dias depois, em 15 de junho, os operários organizaram um ato público na porta da fábrica e quinze mil pessoas estiveram presentes para apoiá-los (MAI, 1973 , p. 11).

Com os relógios nas mãos e a fábrica sob seu controle, os operários se viram num dilema. $\mathrm{O}$ valor dos relógios do estoque representava, no máximo, quatro meses de salários iguais para todos. Então, em uma assembleia realizada no dia 18, o coletivo aprovou a proposta do comitê: religar as máquinas e usar os materiais disponíveis na fábrica para produzir relógios e vendê-los pelo preço de mercado. E, para gerir o processo, colocaram em prática um método de deliberação e decisão coletiva peculiar, que envolvia um sistema de reuniões diárias em vários níveis (MAI, 1973, p. 12-3).

A ocupação foi difundida por toda a França e muitos outros países, a ponto de os trabalhadores terem montado um sistema de recepção de visitantes, com uma cafeteria e uma programação de eventos, sempre com o objetivo explícito de explicar e popularizar sua luta. Eles produziram, também, um jornal semanal, o Lip-Unite, que chegou a uma circulação de 30 mil exemplares em setembro. E um programa de rádio, o Radio Lip, distribuído em fitas cassete à comunidade (RADICAL AMERICA, 1973, p. 14).

Mas a experiência de controle chegou a um rápido fím. Após uma declaração de falência da fábrica pelo judiciário, em julho, a ocupação terminou no dia 14 de agosto de 1973, com um ataque policial feito no início da madrugada, no período de férias, em que a fábrica estava esvaziada. Os atos de luta dos operários continuaram, nos moldes típicos, com reivindicações contra cortes e contra o fechamento da fábrica, mas foram enfraquecendo diante da conjuntura desfavorável. O uso da força pelo governo reduziu a intensidade da luta e, pela primeira vez, rompeu a união dos trabalhadores. Seus atos de propaganda começaram a perder o 
efeito e os líderes das centrais sindicais retiraram seu apoio. A experiência, então, chegou ao fim $^{7}$ (RADICAL AMERICA, 1973, p. 15-6).

O que nós devemos extrair de fundamental dessa experiência operária extraordinária, de grande valor histórico, é que ela foi uma luta por controle e se deu independentemente do sindicato. Não uma luta que reivindicava o controle, mas uma luta por assumi-lo, por colocar as mãos nele (BERNARDO, 1999, p. 40). "O controle não aparece como uma palavra de ordem. Aparece como algo prático e realizado" (BERNARDO, 1999, p. 41). É uma experiência que mostra quais são os limites da organização e da ação sindical, cujo pressuposto é de que o controle da empresa é dos patrões, e aos operários cabe reivindicar melhoras, nada além disso. Tendo conquistado uma organização coletiva sofisticada, os trabalhadores da Lip impuseram sua vontade e fizeram a gerência sentir que não tinha, mais, o controle da fábrica. Apesar de os trabalhadores da Lip não terem declarado que sua intenção era tomar o controle da produção em definitivo (eles descreviam sua ação como “autodefesa, e não autogestão"), eles afirmaram em seu manifesto: "Nós mostramos que os patrões não são indispensáveis e que os trabalhadores são capazes de organizarem-se, por si só, mesmo na esfera econômica [...]. Não é apenas a gerência da Lip que foi desafiada, mas toda a classe patronal" ${ }^{8}$. E seu ato foi, de fato, sentido como uma ameaça pelos capitalistas. Em uma revista patronal francesa se escreveu:

[...] a sociedade francesa, como é concebida pelo governo e pelas classes dominantes, raramente foi tão ameaçada em seus princípios como agora, em razão do caso Lip. [...]Calmamente, e sem nenhum grande tumulto, [o caso Lip] está negando ou transformando os direitos de propriedade [...], e está fazendo tudo isso com o suporte moral de grande parte da população. ${ }^{9}$

O caso Lip não apenas ficou internacionalmente famoso, como foi largamente imitado. Como conta Paul Singer, a luta da Lip "durou vários anos e foi tão entusiasmante, na época, que cerca de 700 empresas foram tomadas pelos seus trabalhadores por efeito do exemplo dos trabalhadores da Lip" (SINGER, 1999, p.

\footnotetext{
${ }^{7}$ Vale informar que a fábrica retomou sua produção, na forma usual capitalista, e é, até hoje (2013), uma das maiores produtoras de relógios da França. Sua página na internet é: 〈http://www.lip.fr.>

${ }^{8}$ Tradução livre de: "[We] have shown that the bosses are not indispensable and that the workers are capable of organizing themselves, on their own, even in the economic sphere... It is not only the management of Lip that has been challenged, but the whole employing class".

${ }^{9}$ Tradução livre de: "This challenge was also apparent to the employers. In an article on the seizure of the factory, an employer's magazine observed that 'French society as it is conceived by the government and the ruling classes, has rarely been so threatened in its principles as now, to judge by the Lip affair. (...) Calmly, and without any great distress, it is denying or transforming property rights..., and it is doing all this with the moral support of the greater part of the population".
} 
25).

A partir daí, ocupações ocorreram em todo o mundo, sempre aumentando em número e intensidade nos períodos de crise (que necessariamente chegam, pois as crises são cíclicas e estruturais no modo de produção capitalista).

Nos anos 80, ficou conhecida a ocupação, no Canadá, da empresa British Columbia Telephone Company, iniciada em $1981^{10}$.

Nas décadas de 1990 e 2010, em resposta à crise neoliberal, uma grande explosão de ocupações estourou na América Latina, com ocupações no Brasil, Argentina e Uruguai (NOVAES, 2007, p. 84), de modo que parte significativa dessas empresas está funcionando sob controle operário até hoje (HENRIQUES et al., 2013, p. 49-55). Depois da virada do século,

[...] no plano mundial, com a sucessão e o aprofundamento das crises econômicas a partir de 2001, o que se percebe é o surgimento de experiências de recuperação de empresas pelos trabalhadores em diversos países, como por exemplo na Espanha, Grécia, Indonésia, Canadá, Irlanda, Sérvia, Egito, Tailândia, Paraguai, México, Bolívia e nos Estados Unidos, para além das múltiplas iniciativas em curso na Argentina, Venezuela e Uruguai (DAGNINO \& NOVAES, 2013, p. 205).

Já nesta década de 2010, que está apenas se iniciando, os dois casos mais relevantes já foram mencionados. O da New Era Windows Cooperative, nos EUA, fábrica de produtos de vidro que, vítima da crise financeira de 2008, foi ocupada e retomou sua produção em maio de 2013 sob o controle operário (NEW ERA WINDOWS COOPERATIVE, 2013), e o da Vio.Me., na Grécia, fábrica de materiais para construção que foi ocupada após entrar em crise, em 2010, e religou suas máquinas em fevereiro de 2013 (OPEN INITIATIVE OF SOLIDARITY AND SUPPORT, 2013).

Este consistente movimento gerou e está gerando, também, reflexos no plano cultural, no plano dos meios de comunicação e no plano científico.

No plano cultural, houve a produção do interessante documentário The Take (2004), sob a direção dos entusiastas Avi Lewis e Naomi Klein, que conta o início da história das ocupações de fábricas na Argentina e foi produzido ainda no calor de sua deflagração. E, além disso, o conhecido documentarista estadunidense Michael

\footnotetext{
${ }^{10}$ Sobre esta experiência: Azzellini \& Ness (2011, p. 338).
} 
Moore dedicou parte de seu último documentário, Capitalismo: uma história de amor (2009), à ocupação da fábrica New Era Windows Cooperative, tratando com otimismo da possibilidade de controle operário na produção como um caminho alternativo ao capitalismo.

No plano dos meios de comunicação, além das muitas matérias jornalísticas já publicadas, geralmente em resposta a uma nova ocupação relevante ou a uma conquista legislativa, há alguns portais na internet que servem permanentemente e exclusivamente à difusão de informação relativa à recuperação de empresas. Vale dizer que muitos já foram criados, mas, após certo tempo, foram excluídos ou deixaram de ser atualizados. Citamos dois de nosso conhecimento que se estabilizaram e mantêm atualizações constantes. O portal www.workerscontrol.net, fundado pelos professores Dario Azzellini (Universidade Johannes-Kepler, Áustria), Ralf Hoffrogge (Universidade Potsdam, Alemanha), e Alan Tuckman (Universidade de Nottingham, Reino Unido), que contém informações de experiências de todos os continentes e, segundo sua própria descrição, "pretende ser uma livraria virtual aberta para documentação e teoria sobre experiências de controle operário passadas e atuais". E o portal www.elcambiosilencioso.com.ar, fundado pelo professor Esteban Magnani (Universidade de Buenos Aires, Argentina), que, em meio a uma quantidade considerável de material, se destaca pelas informações sobre os casos de ERTs da Argentina.

No plano científico, o fenômeno e a ideia da recuperação de fábricas já empolgou e continua empolgando muitos membros da academia. Apenas no Brasil, temos Lorena Holzman, Maurício Sardá de Faria, Lia Tiriba, Neusa Dal Ri e Candido Vieitez, Paulo Marques, Henrique Tahan Novaes e Alessandra Azevedo, que produziram pesquisas nas últimas décadas (DAGNINO \& NOVAES, 2013, p. 15). Além da publicação de diversas obras importantes. Citamos quatro de nosso conhecimento. O livro El cambio silencioso: empresas y fábricas recuperadas por los trabajadores en la Argentina, do professor da Esteban Magnani (MAGNANI, 2003), primeiro sobre a explosão de recuperação operária latinoamericana, produzido em conjunto com o documentário de Avi Lewis e Naomi Klein logo no início desse movimento na Argentina. O livro Empresas Recuperadas por Trabalhadores no Brasil, publicado neste ano de 2013, que reflete um momento mais maduro, fruto de um esforço de membros de dez universidades brasileiras para, pela primeira vez, 
mapear e conhecer a totalidade dos casos de ERTs no Brasil (HENRIQUES et al., 2013). O livro Las Empresas Recuperadas en la Argentina: informe del tercer relevamiento de empresas recuperadas por sus trabajadores, a terceira edição do projeto de mapeamento totalizante do fenômeno na Argentina, que inspirou, inclusive, o projeto brasileiro (RUGGERI et al., 2010). E, por último, fornecendo uma perspectiva mais abrangente e internacional, a obra coletiva Ours to master and to own: Workers' Control from the Commune to the Present, coordenado pelos professores Dario Azzellini e Immanuel Ness (Universidade da Cidade de Nova Iorque, EUA); a obra tem diversos artigos que tratam de experiências de recuperação de empresas em vários lugares do mundo (AZZELLINI \& NESS, 2011).

Por fim, em diversos casos, o movimento logrou conquistas importantes junto ao poder público, com a aprovação de leis e a instituição de políticas públicas específicas. Além dos casos da Argentina e Uruguai, dos quais vamos tratar mais à frente,

[...] hoje a recuperação de empresas é favorecida pela legislação na Itália e o novo Ministro da Economia Social e Solidária da França propõe que seu país adote lei que torne obrigatório o oferecimento de qualquer empresa a ser fechada aos empregados para que a recuperem, se assim o desejarem (DAGNINO \& NOVAES, 2013, p. 10).

Assim, nossa investigação nos permite afirmar que, desde 1973, o fenômeno da recuperação de fábricas se tornou perene. E que, apesar de, provavelmente, a maioria das ERTs em funcionamento hoje estarem isoladas e serem instáveis, estamos, neste momento de nossa história, presenciando um desenvolvimento desse movimento, com ocupações cada vez mais longas e sofisticadas, e com a criação de organizações e redes que as unem e fortalecem.

O que isso significa?

Uma empresa que funciona sob o controle de trabalhadores não é a revolução, a superação da barbárie e da tristeza que é o sistema social capitalista. Mas tem o potencial de principiar uma caminhada revolucionária. Dentro de cada microexperiência de recuperação economicamente bem sucedida, os trabalhadores podem realizar uma de duas coisas: reproduzir a relação social de produção capitalista, com sua organização baseada na hierarquia e divisão desigual do trabalho (organização que, para nós, é a fonte de tudo que é fundamental da estrutura global 
capitalista); ou criar um novo modelo de relação produtiva, que também funcione em termos de possibilitar materialmente a vida humana, mas numa organização estruturada horizontalmente, com igualdade entre os produtores na divisão do trabalho. Como a tarefa de criar esse novo modelo não tem nada de fácil (pelo contrário), não temos dúvida de que, hoje, a maciça maioria delas está reproduzindo as relações produtivas capitalistas, com os líderes operários na função de gestorespatrões ${ }^{11}$. Talvez, todas estejam nessa situação. Por outro lado, em muitas delas, há grande vontade de se realizar algo novo, de transformar as estruturas ${ }^{12}$. Esse desejo coletivo, unido ao cotidiano das práticas criativas dos trabalhadores na peleja por realizar a produção, é o contexto fértil para que seja criado o protótipo da nova organização produtiva. Portanto, é justificado crer no potencial desse movimento.

Essa é, pois, a origem e a história desse jovem movimento, o movimento da continuação de empresas via gestão operária. Conhecendo-a, temos motivos de sobra para acreditar que ele carrega consigo um grande potencial transformador.

11 Isso é mostrado, para as experiências brasileiras, no mapeamento publicado em 2013 (HENRIQUES, 2013, p. 70-83 e 103-132).

${ }^{12}$ Vemos, também, a existência dessa vontade no mapeamento; no fato, por exemplo, de que $97 \%$ das empresas se declaram autogestionárias e $66 \%$ realizam reuniões assembleares com frequência (HENRIQUES, 2013, p. 116 e 200-1). 


\title{
1.3 “Ocupar, Resistir, Produzir!”: a posição destacada da América Latina no movimento das ERTs
}

\begin{abstract}
Em uma reportagem no jornal Página 12 do dia 20 de novembro de 2012, os pesquisadores Julian Rebón e Rodrigo

Salgado da Universidade de Buenos Aires revelaram dados de uma pesquisa feita com 600 pessoas da área metropolitana de Buenos Aires, na qual 70\% dos entrevistados demonstraram conhecer o fenômeno das empresas recuperadas. Destes, $97 \%$ apresentaram uma ideia positiva desta prática como uma forma de preservar fontes de trabalho e $86 \%$ considera justo que haja ocupação de fábricas para que estas sejam recuperadas.
\end{abstract}

(HENRIQUES, 2013, p. 189)

A fase atual do movimento de continuação operária de empresas iniciou-se com um caso paradigmático europeu, como visto. Entretanto, é possível afirmar que, hoje, seu centro avançado está na América Latina.

No Brasil funcionam, hoje, 67 empresas recuperadas por trabalhadores. $\mathrm{Na}$ vizinha Argentina, o país com mais casos no mundo e, provavelmente, o centro mundial do fenômeno, há mais do que o triplo: pelo menos 205 empresas em atuação (HENRIQUES et al., 2013, p. 39).

A maioria dessas empresas foi tomada por seus trabalhadores numa mesma época: as décadas de 1990 e 2000. Foi o definitivo ingresso latino-americano no cenário das recuperações operárias. Saberemos o porquê.

Antes, entretanto, vale informar que chegaram a ocorrer recuperações esparsas na América Latina em períodos anteriores. Elas marcaram o início do processo no continente, e o pioneirismo do Brasil, que foi o primeiro na região a ter experiências de recuperação (HENRIQUES et al., 2013, p. 28). Os três casos mais importantes foram o da Wallig (indústria de fogões, Porto Alegre/RS), o da Cooperminas (extração de carvão mineral, Criciúma/SC) e o da Tecelagem Parahyba (produção de cobertores, São José dos Campos/SP e Recife/PE) (SINGER, 2012, p. 87). Entre essas, se sabe que a Cooperminas e as duas cooperativas formadas a partir 
da Tecelagem Parahyba (Coobertores Parahyba, no PE, e Coopertêxtil, em SP) ainda estão em operação, contando, no total, com pouco mais de mil trabalhadores em atividade atualmente (HENRIQUES et al., 2013, p. 51 e 244-7).

Entretanto, como já mencionamos, uma característica fundamental do fenômeno das ERTs é que ele é um produto da crise estrutural do capital, pois é reflexo de uma conjuntura em que empresas fecham e o desemprego é alto (HENRIQUES et al., 2013, p. 14).

Em conformidade com isso, a real detonação do movimento no Brasil e na América Latina ocorreu justamente em seguida à aguda crise neoliberal sofrida na última década do século XX. O colapso foi resultado de uma ação ofensiva do capital para retomada da acumulação perdida nos anos 1970, com "privatizações, reestruturação produtiva, biocolonialismo, livre circulação do capital financeiro, contrarreforma do Estado e mercantilização de todas as esferas da vida" (HENRIQUES et al., 2013, p. 14-5). A manobra gerou fechamento de muitas empresas e demissões em massa, com consequências cruéis para a classe trabalhadora. Para entender a amplitude dessa crise, basta saber que, apenas entre 1996 e 1999, no Brasil, 24 mil empresas faliram. Na Argentina, o período mais crítico se deu entre 1998 a 2001, com 3,5 mil falências por ano (VERAGO, 2010b, p. 13).

Estavam postas as condições para a expansão das recuperações operárias. Estavam postas as condições para que a palavra de ordem "Ocupar, Resistir, Produzir!", hoje o lema mundial dos movimentos de recuperação, emergisse na arena da luta de classes.

Do total de ERTs que operam hoje no Brasil, $89 \%$ iniciaram seus processos de recuperação entre os anos de 1990 e 2009 (HENRIQUES et al., 2013, p. 51). Foram 54 tomadas operárias, sem considerar muitas outras que, por diversas razões, não estão mais ativas ${ }^{13}$.

A primeira, que se tornou a referência brasileira em termos de luta dos trabalhadores e metodologia de transferência da propriedade, foi a fábrica de sapatos Makerly, de Franca (SP). A fábrica entrou em crise em 1991, em razão da abertura do mercado à concorrência internacional. Então,

13 Há pelo menos 78 experiências brasileiras de recuperação operária que não estão mais ativas (HENRIQUES et al., 2013, p. 248-251). 
os trabalhadores encamparam a idéia do sindicato e se propuseram a adquirir o maquinário dos donos da Makerly por 600 mil dólares. Para conseguir o crédito correspondente do Banespa (Banco do Estado de São Paulo, banco oficial do Estado de São Paulo, hoje vendido ao Santander) foi necessária intensa luta política, que culminou com a ocupação da sede do Banespa em Franca. Após 91 dias de pressão e negociações, assinou-se um acordo pelo qual, como garantia do empréstimo, $49 \%$ das ações da empresa ficaram com o banco. Por esse acordo, a Makerly teve de continuar sendo uma sociedade anônima, e não uma cooperativa. Controlada pelos trabalhadores, a empresa funcionou nos anos seguintes com êxito, até que em março de 1995 o governo federal interveio no Banespa e suspendeu a linha de crédito à Makerly, o que impôs o encerramento de suas atividades (SINGER, 2012, p. 88).

A experiência ficou conhecida e "gente de todo o país, sindicalistas, políticos, trabalhadores, imprensa, todos iam até Franca para conhecer a experiência que eles denominaram 'fábrica de trabalhador"” (Anteag apud SINGER, 2012, p. 889).

Em seguimento, nesta época, "outras empresas, em geral grandes e antigas, entraram em crise e acabaram se tornando autogestionárias: Facit, Hidro-Phoenix etc. (SINGER, 2012, p. 89)".

Neste momento, temos a primeira ação de articulação do movimento. Em 1994, em São Paulo, é realizado $1^{\circ}$ Encontro dos Trabalhadores em Empresas de Autogestão. $\mathrm{O}$ encontro contou com a participação de representantes de seis empresas, e seu principal resultado foi a criação da ANTEAG: Associação Nacional dos Trabalhadores em Empresas de Autogestão e Participação Acionária. Como explica Singer, “a Anteag surge não só para ajudar a luta dos trabalhadores pela preservação de seus postos de trabalho e ao mesmo tempo pelo fim de sua subordinação ao capital, mas também para assessorar as novas empresas solidárias” (2012, p. 89).

E essa assessoria era necessária. Como explica Nakano,

os projetos precisavam ser coordenados porque, mesmo que inicialmente pressionados pelo desemprego, quando os trabalhadores assumiam as empresas tinham de enfrentar inúmeras questões, novas para eles, entre elas aquelas relativas ao mercado e à comercialização dos produtos, ao acesso a crédito e controle orçamentário da empresa, à organização do trabalho e da produção, à tecnologia, à legislação. Se, por um lado, as relações de solidariedade entre trabalhadores, o apoio de alguns sindicatos às suas iniciativas eram fundamentais, por outro, não eram suficientes. Havia necessidade de articular pessoas e instituições, 
democratizar informações, criar um espaço para o debate e produção de alternativas. Enfim, havia a necessidade de uma entidade que assumisse esses papeis. Era o começo da Anteag (apud SINGER, 2012, p. 89).

O debate sobre autogestão e cooperativismo se aprofundou no movimento sindical (GUIMARÃES, 1999) e as tomadas operárias continuaram.

Pouco tempo depois, em 1999, outra manobra importante: os Sindicatos dos Metalúrgicos e dos Químicos da região do $\mathrm{ABC}$ se unem e criam a UNISOL (Central de Cooperativas e Empreendimentos Solidários) - São Paulo. E, depois, em 2004, com o apoio da ADS (Agência de Desenvolvimento Solidário) da CUT, cria-se a UNISOL - Brasil. "Essas organizações, juntamente com a ANTEAG, se tornaram as principais assessorias dessas experiências no país" (HENRIQUES et al., 2013, p. 36-7).

Além disso, em 2002, a partir da ocupação das fábricas Cipla e Interfibra, em Santa Catarina, é criado o Movimento das Fábricas Ocupadas (MFO), o qual, adotando a bandeira da estatização sob controle operário, chega com um posicionamento político bem mais marcado em comparação com as demais organizações (HENRIQUES et al., 2013, p. 37).

Para além dessas organizações pioneiras, o mapeamento publicado (Henriques et al., 2013, p. 167-8) identificou outras que também agregam e/ou assessoram ERTs atualmente: a OCB (Organização das Cooperativas do Brasil), o FBES (Fórum Brasileiro de Economia Solidária), a FASE (Federação de Órgãos para Assistência Social e Educacional), a AVESOL (Associação do Voluntariado e da Solidariedade), o SOLTEC (Núcleo de Solidariedade Técnica/UFRJ) e o ITCP/NESOL/USP (Incubadora Tecnológica de Cooperativas Populares / Núcleo de Apoio às Atividades de Extensão em Economia Solidária). Além dessas, temos conhecimento de mais duas: a FETRABRAS (Federação Nacional dos Trabalhadores Cooperados) e a OCESP (Organização das Cooperativas de São Paulo).

Na década atual (2010), que ainda está se iniciando, já se tem notícia de três recuperações operárias no Brasil (HENRIQUES et al., 2013, p. 51). E acrescentamos mais uma, de nosso conhecimento pessoal, que se iniciou durante o desenvolvimento desta pesquisa: no dia 03 de dezembro de 2013, a cooperativa Cocepelco, formada por ex-empregados, recebeu autorização judicial para assumir a empresa falida 
Nobrecel Celulose e Papel, na cidade de Pindamonhangaba-SP, região do Vale do Paraíba, interior de São Paulo, com apoio da UNISOL, da FETRABRAS e da OCESP $^{14}$.

Parece, portanto, que cada vez mais a recuperação operária se coloca como uma possibilidade para os trabalhadores no Brasil. E o mesmo ocorre, com intensidade muito maior, na Argentina, o caso mais destacado.

A experiência argentina foi deflagrada, também, na década de 1990, tendo alcançado sua máxima expressão no biênio 2001/2002 (ANTIERO et al., 2012, p. 13). É possível afirmar que seu processo foi ainda mais intenso que o brasileiro, com casos notáveis em termos de combatividade operária, sucesso econômico e sofisticação de organização coletiva.

Há, por exemplo, o caso da Fasinpat Cooperativa, ex Cerámicas Zanón, que construiu uma relação incrível com sua comunidade colocando em prática a ideia de uma fábrica a serviço da comunidade, numa postura que Novaes qualifica como a incorporação da função de Fábrica-Estado (2007, p. 95). Logo após a retomada operária, passaram a doar, com frequência, pisos e azulejos para a construção de escolas e hospitais locais. A fábrica sempre recebe eventos sociais, como shows musicais, e, no ano de 2009, passou a abrigar uma escola primária e secundária, onde estudam trabalhadores, filhos de trabalhadores e vizinhos. Com o apoio incrível que angariou em sua comunidade, a Fasinpat resistiu a diversas tentativas oficiais de despejo e logrou junto ao poder público a expropriação da planta no final de 2012. Hoje, a Fasinpat ocupa 450 trabalhadores e produz 300 mil metros quadrados de produtos cerâmicos por mês, inclusive para exportação (GIAMBELLUCA, 2012).

Outro caso notável é o do Hotel Bauen, um hotel localizado no centro da capital portenha e que foi assumido por seus trabalhadores em 2003, após uma crise derivada de diversos atos fraudulentos dos antigos donos. Seus trabalhadores encabeçam a FACTA, uma das organizações de ERTs mais importantes do país, e os

\footnotetext{
${ }^{14}$ Vide notícia sobre esse fato no endereço: <http://valenews.com.br/geral/17184-cocepelco-assumedirecao-da-nobrecel-e-gera-1150-empregos-para-pinda-e-regiao.html>. Vale dizer que, até o momento, não é possível apontar definitivamente essa experiência como um caso de ERT. Por duas razões: primeira, é necessário aguardar a efetiva retomada da produção e sua consolidação; segunda, deve ser verificado se, na prática, adotará um formato mínimo de gestão coletiva (sobre isso, vejam-se os critérios metodológicos aplicados no mapeamento realizado no Brasil (HENRIQUES et al., 2013, p. 31-3)).
} 
recursos que conseguiram reservar a partir daí já permitiram reinvestimentos no prédio de quase quatro milhões de pesos.

Há muitos outros casos notáveis, como os da produtora de trajes masculinos Brukman, da gráfica Chilavert e da metalúrgica Unión y Fuerza, todas ativas até hoje. Como afirma Alexandre Mandl, militante do Movimento das Fábricas Ocupadas brasileiro,

o caso argentino é um referencial quando tratamos de fábricas ocupadas justamente pelo seu protagonismo, sua força popular, sua capilaridade junto à população, com as fábricas abertas à comunidade, articulando atividades culturais, educacionais e esportivas, que mostram o significado de uma fábrica sem patrão (2012).

Além disso, o movimento neste país se destaca pelos maiores esforços de articulação entre as empresas operárias. Como afirmam os pesquisadores que realizaram o recente mapeamento brasileiro,

outra diferença com relação aos casos argentinos é que nas experiências brasileiras identificamos que são frágeis e esporádicos os vínculos entre as ERTs, e destas com um movimento social mais amplo, capaz de pautar as demandas dos trabalhadores das ERTs e, também, de politizar o debate visando impulsionar práticas para além da lógica do capital. Nesse sentido, vale ressaltar o que foi apresentado no Capítulo 10 acerca do distanciamento das ERTs brasileiras do movimento de economia solidária e também dos demais movimentos sociais existentes, inclusive para ações para além dos muros das empresas, que pudessem envolver ao menos as associações comunitárias localizadas no entorno das instalações. Ao contrário disso, as experiências argentinas de ERTs vêm estabelecendo fortes vinculações territoriais e atividades para além da produção de mercadorias, com a construção de escolas, centros culturais e de espaços de lazer para os vizinhos e comunidade do entorno (HENRIQUES et al., 2013, p. 205) ${ }^{15}$.

Com essa história, a força atual do fenômeno na Argentina é surpreendente.

Mesmo que o país não tenha passado por outra crise intensa desde aquela decorrente da ofensiva neoliberal, as novas recuperações continuaram em intensidade razoável, e as experiências existentes se desenvolveram (HENRIQUES, 2013, p. 190). Salta aos olhos a pesquisa do Página/12 realizada em 2012, mencionada por Flávio Chedid Henriques no trecho que usamos como epígrafe, em que $70 \%$ dos entrevistados da região metropolitana de Buenos Aires afirmou conhecer o fenômeno das empresas

15 Para uma compreensão da configuração concreta dos movimentos de ERTs argentinos, recomendamos o artigo "O atual estágio das relações entre as empresas recuperadas (ERs) argentinas e o movimento operário argentino e latino-americano”, de Josiane Verago. 
recuperadas, 97\% desses apresentou uma ideia positiva dessa prática e 86\% considera justo que se ocupem fábricas para recuperação. Como pondera o pesquisador, "não há uma pesquisa no Brasil similar a esta que permita fazer uma comparação com os dados obtidos, mas é evidente o desconhecimento que a população brasileira tem da prática de recuperação de empresas” (2013, p. 189).

Tudo indica, portanto, que na Argentina atual, e, com menor intensidade, também no Brasil, a continuação de empresas via gestão operária é uma possibilidade aberta à classe trabalhadora. É essa, também, a visão dos pesquisadores argentinos Antiero, Elena e Ruggeri, que afirmam em cartilha escrita para os trabalhadores das recuperadas:

as empresas recuperadas chegaram para ficar e seguir crescendo, e se converteram numa expressão de luta e de defesa do trabalho internalizada pelo conjunto da classe trabalhadora. $\mathrm{O}$ fato de que, incluindo no marco do crescimento econômico dos últimos anos, se seguem recuperando empresas, o demonstra (2012, p. 33).

Outro fato que demonstra o protagonismo do continente são as conquistas legislativas na Argentina, Uruguai e Venezuela. Em 2011, na Argentina, o legislativo nacional alterou a lei de falências para considerar sistematicamente e oficialmente a possibilidade de continuação da atividade empresarial por uma cooperativa formada pelos ex-empregados da empresa falida (o diploma alterador é a Ley $\mathrm{n}^{\circ} 26.684$ de 29/06/2011). Em 2006, no Uruguai, o executivo aprovou o Decreto $n^{\circ} 165 / 2006$ prevendo explicitamente a greve de ocupação como modalidade de exercício do direito de greve, algo inédito. E na Venezuela, país que vive o processo político revolucionário chavista, mais de mil fábricas já foram nacionalizadas após terem sido recuperadas por seus trabalhadores, com apoio no artigo 70 da Constituição nacional, que prevê que "são meios de participação e protagonismo do povo no exercício de sua soberania [...] a autogestão, a cogestão, as cooperativas em todas as suas formas incluindo as de caráter financeiro, as caixas de crédito, a empresa comunitária e as demais formas associativas guiadas pelos valores da mútua cooperação e da solidariedade" (MANDL, 2012).

Vemos, portanto, que, se há um anseio global da classe trabalhadora por controlar a produção, e se a sua forma mais radical é o movimento de ocupação e recuperação de fábricas, o centro mundial desse movimento está na América Latina. E é significativo o fato de que um órgão de financiamento fundado por entusiastas 
norte-americanos, o The Working World, tenha tido sua primeira sede na Argentina, em 2005, a segunda na Nicarágua, em 2008, e somente depois nos EUA, em 2011 (THE WORKING WORLD, 2013). E é significativo, também, o fato de que a palavra de ordem “Ocupar, Resistir, Produzir!", hoje adotada por operários do mundo todo, tenha sido emprestada de um tradicional movimento social brasileiro, o MST. Estamos no olho desse furacão da história.

\subsection{O MFO e a Fábrica Ocupada Flaskô: um olhar para além do capital}

É certo que a partir do Projeto da Fábrica de Cultura e Esportes o vínculo com a comunidade aumentou. Mais de 400 atividades culturais e sociais, além de dezenas de atividades esportivas, foram realizadas nos galpões abandonados da Flaskô.

Alexandre Mandl, militante do MFO (2012)

Já vimos que há, hoje, muitas experiências de recuperação operária em atividade no Brasil. Cada uma delas tem suas próprias características: seus pontos fortes e fracos, sua história de luta peculiar, sua saúde financeira, sua maior ou menor realização do ideal de gestão coletiva, seu foco maior ou menor para além da mera sobrevivência no mercado capitalista.

Nem todos os coletivos operários que se lançam à recuperação de sua empresa decidem colocar para si mesmos um objetivo para além do capital. $\mathrm{Na}$ verdade, no Brasil, tudo leva a crer que as ERTs estão num momento de despolitização (DAGNINO \& NOVAES, 2013, p. 24).

Por isso, queremos destacar um caso que se distingue pela combatividade e pelo posicionamento declaradamente revolucionário. É o caso da Fábrica Ocupada Flaskô, única empresa que articula, hoje, o Movimento das Fábricas Ocupadas (MFO), fundado em 2002 pelos trabalhadores da Cipla, de Joinville-SC. 
A Flaskô é uma fábrica de produtos plásticos localizada na cidade de Sumaré, da região metropolitana de Campinas, no interior de São Paulo. O início de sua história de tomada operária não difere, no fundamental, do de outras ERTs.

A Flaskô, assim como a Cipla e a Interfibra, pertencia ao grupo empresarial HB (Hansen Batschauer), uma ramificação do conhecido Grupo Tigre, da família Hansen. O grupo HB chegou a ter 39 empresas em todo o país (NAPOLEÃO, 2005, p. 4). Mas,

com a abertura econômica do governo Collor, e depois com FHC, somando-se à má gestão e diversas fraudes e sonegações, houve grande liquidação do patrimônio, demissões em massa, fechamento de plantas industriais, sendo que somente resistiram três fábricas (MANDL, 2011).

O auge da crise se deu em 2002 e atingiu em especial a Cipla, planta maior em tamanho e economicamente mais importante. Entre janeiro e outubro desse ano os trabalhadores dessa fábrica sofreram com atraso de salários, demissões e promessas vãs. E, neste contexto, descobriram que a empresa não depositava o benefício do FGTS para os empregados há mais de 10 anos. Mesmo com a falta de apoio de seu sindicato, os trabalhadores promoveram greves e mobilizações para reivindicar o pagamento dos salários em atraso e o fim das demissões. Em sua luta firme, angariaram apoio de militantes da CUT e do PT, do movimento estudantil, do Ministério Público, da Delegacia Regional do Trabalho e de vereadores municipais. E, enfim, em 24 de outubro iniciaram uma greve, que se encerraria somente oito dias depois com uma decisão: ocupar da fábrica com a intenção de retomar a produção sob o controle operário (NAPOLEÃO, 2005, p. 10-2). Nos meses seguintes foram ocupadas, também, a Interfibra e a Flaskô, plantas economicamente ligadas à Cipla.

Não foram três ocupações isoladas. Pelo contrário, desde o início, os coletivos operários de cada fábrica agiram em articulação. E, aqui, a história dessas três ERTs começa a se distinguir. Religadas as máquinas, os pouco mais de mil trabalhadores das três plantas se viram à frente do dilema que se coloca após cada retomada operária: o que fazer para estabilizar juridicamente a gestão operária? Formar uma cooperativa? Estatizar? "As alternativas foram debatidas desde novembro de 2002 pelos trabalhadores, obtendo a estatização uma maior aceitação, relevando tratar-se de empresas que disponibilizam produtos para a Petrobrás [...]" (NAPOLEÃO, 2005, p. 12-3). 
Assim, as três ocupações passaram a assumir essa bandeira diferenciada: reivindicar a estatização sob controle operário. Divergindo, com isso, do que eles identificaram como a bandeira da economia solidária. Foram as primeiras, no Brasil, a adotarem essa posição. E, logo, criaram o Movimento das Fábricas Ocupadas, que teria o objetivo de articular essas três ocupações e suas reivindicações, e, também, de intervir em outras tomadas operárias para difundir a bandeira da estatização sob controle operário (MANDL, 2011). Então, nesse contexto e com essa peculiaridade, nasceu o MFO.

O que faz com que o MFO - e a ocupação da Flaskô, única ERT atual que articula esse movimento - mereça ser destacado entre as experiências brasileiras é, em nossa visão, seu olhar para além do capital. Sua intenção declarada de superar o capitalismo e construir o socialismo. Como já dissemos, há pelo menos 67 ERTs no Brasil. E há muitas delas que explicitamente renegam qualquer objetivo revolucionário. "Queremos manter nossos empregos", é esse seu discurso (HENRIQUES et al., 2013, p. 45-6 e 191-203).

No entanto, para que as ERTs se tornem, de fato, um caminho para transformar nossa sociedade, entendemos ser necessário que os trabalhadores tenham suas consciências voltadas a este objetivo, além do da sobrevivência (que, evidentemente, sempre estará presente e será determinante).

Por isso a importância da Flaskô ${ }^{16}$.

E é interessante perceber que, ao adotar essa postura revolucionária, a ERT se organiza e age de maneira diferente. Em especial, ela inova em sua organização interna, com reflexos nas relações entre trabalhadores e na estruturação das condições de trabalho; e, também, em seus atos na relação com a comunidade que a cerca.

Com relação à organização interna, a Flaskô, além de levar os trabalhadores a participarem da gestão (por meio de assembléias gerais mensais e de um conselho de fábrica eleito anualmente), o que reduz ou elimina a alienação, também reduziu a

\footnotetext{
${ }^{16}$ Vale dizer que, em nossa visão, um olhar para além do capital não implica, necessariamente, a adoção da bandeira da estatização. Esse é um caminho de intenção revolucionária, mas acreditamos que há outros possíveis para ERTs. É possível olhar para além do capital sem olhar para a estatização. Não temos espaço, aqui, para explicitar o porquê de nossa visão, mas basta dizer que acreditamos que a superação do modo de produção capitalista se dará pela criação de uma nova organização produtiva, e não pela tomada do poder do Estado.
} 
jornada de trabalho de 44 para 40 e, depois, 30 horas semanais (6 horas diárias). E adotou um ritmo de trabalho menos intenso, o que implicou na inexistência de acidentes laborais graves desde a recuperação (MANDL, 2011).

Na questão da relação com a comunidade, a Flaskô é, hoje, um espaço de convivência e socialização, além de ser um espaço de produção. Como já mencionamos, seu coletivo operário colocou em prática o "Projeto da Fábrica de Cultura e Esportes" e já realizou mais de 400 atividades culturais e sociais no interior da fábrica (MANDL, 2012), como debates, shows musicais, apresentações teatrais, oficinas de quadrinhos e campeonatos de judô, xadrez, damas e violão. Na área esportiva, a Flaskô construiu, em 2012, em um galpão sem uso, uma pista de skate aberta, para uso gratuito pela comunidade, onde já aconteceram três campeonatos. Além disso, a gestão operária, em conjunto com associações de bairros da periferia de Sumaré, destinou a maior parte do terreno onde está a fábrica (que ficava vazio, pois os muros da fábrica ocupam apenas $1 / 4$ do total da propriedade) para uma ocupação de moradia, criando, em 2005, a Vila Operária e Popular, que abrigava, em 2012, 564 famílias. Não bastasse, num contexto social mais amplo, a Flaskô tem fortes relações de apoio e articulação com movimentos sociais importantes como o MST, o MTST e o MTD (MANDL, 2012).

Tudo isso é muito inovador, pois, no modelo tradicional, a fábrica é, necessariamente, um local apático, triste e sem vida, adequado para máquinas, mas não para convivência e felicidade humanas, ou para a luta pela construção de um mundo melhor. E por uma razão muito simples: esse espaço é propriedade de um empresário capitalista e seu único intuito com ele é acumular capital. Quaisquer atividades que escapem disso são, em geral, mal vistas e desestimuladas, pois, para ele - que, em geral, não vai se deleitar delas - elas são apenas fonte de gastos e problemas (do tipo "não lucrativo"). Por isso não tem sentido, para um patrão, promover shows musicais, por exemplo, no galpão da fábrica. Para ele, ali deve acontecer o que gera faturamento. E ponto. Por isso a fábrica é o local frio e desumano que é; a "usina satânica", como chamou Karl Polanyi.

Adotar essa postura combativa, entretanto, tem consequências. O MFO acabou sofrendo, em sua história, diversos ataques originados da classe capitalista, de órgãos do Estado e da imprensa burguesa. As ocupações na Cipla e na Interfibra 
não se encerraram por razões internas. Elas decorreram de uma série de atos ofensivos, cujo ponto culminante foi a decretação judicial de intervenção estatal nas plantas, com invasão policial e passagem do poder de gestão a um administrador externo. Infelizmente, depois desse processo, apenas a Flaskô resiste. No entanto, representando o MFO, ela mantém uma postura ativa e combativa no terreno da luta de classes.

Assim, entre as atuais experiências brasileiras de ERT, a da Flaskô merece destaque por sua postura e sua combatividade. Vale dizer que a Flaskô não está sozinha, não é a única. Fora do Brasil há outras tomadas operárias que declaram objetivos para além do capital, como, por exemplo, as já mencionadas FasinPat, na Argentina, e a New Era Windows, nos Estados Unidos. E mesmo, talvez, haja outras experiências brasileiras que adotem um olhar revolucionário mais amplo, apesar de não ser de nosso conhecimento. Entendemos, vale ressaltar, que a adoção dessa postura é fundamental; um pressuposto para construir algo diferente é direcionar a vontade nesse sentido.

\subsection{Relevância do estudo das experiências de recuperação: um novo caminho}

Nós acreditamos que a ocupação e retomada da operação de fábricas e empresas por seus trabalhadores é a única alternativa realista em face da eternamente crescente exploração da classe trabalhadora.

Trabalhadores da Vio.Me. (ED, 2012)

Pelos fatos e pelas razões que expusemos neste capítulo, é justificável e relevante realizar estudos acerca desse fenômeno atual: a recuperação de empresas por trabalhadores. Tanto na área jurídica quanto em outras áreas das ciências 
humanas e sociais. E, até mesmo, das ciências exatas e biológicas ${ }^{17}$.

E isso é verdade tanto para os que acreditam na vocação revolucionária desse movimento, quanto para os que o veem somente como uma nova alternativa de sobrevivência para a classe trabalhadora.

O movimento das ERTs se insere num movimento maior, de anseio de controle operário da produção e que muitos no Brasil denominam, hoje, economia solidária. Esse movimento já ocupa, atualmente, 2 milhões de trabalhadores. E

ele se afigura, numa situação, que mais do que conjuntural parece ser mundialmente estrutural, de jobless e job loss growth economy, como uma alternativa para os quase 120 milhões dos $160 \mathrm{em}$ idade de trabalhar que permanecem no setor informal e, frequentemente na exclusão econômica e social e à margem da cidadania. $\mathrm{O}$ fato de que apenas 40 milhões de brasileiros possuam carteira assinada e de que quando tudo "funciona" se consegue gerar 1,5 milhão por ano (quantidade inferior ao crescimento da população em idade de trabalhar), dá uma ideia da importância da Economia Solidária e, dentro dela, como sua ponta de lança, [...] das ERTs (DAGNINO \& NOVAES, 2013, p. 17).

Portanto, as experiências de recuperação já têm uma importância inegável na condição de alternativa de sobrevivência da classe trabalhadora. Um novo caminho para que ela não dependa, com tanta intensidade, dos movimentos insensíveis e desumanos do mercado capitalista.

No entanto, ela pode ser mais do que isso. Pode ser um novo caminho para algo maior.

Nosso mundo não vem sendo um bom lugar para a maioria das pessoas. A organização capitalista da vida humana condena nove décimos da população, a classe trabalhadora, à tristeza. Tristeza por ter de viver de um trabalho alienado, desestimulante e opressivo, para a parte dela que tem mais sorte. E, para a outra parte, sem essa sorte, tristeza por viver na miséria, ignorância e violência extremas. É nossa responsabilidade superar o capitalismo e encerrar essa barbárie.

Acreditamos que esse grande movimento de controle operário da produção é o caminho para a realização dessa tarefa. Esse é, também, o pensamento de Dagnino e Novaes, para quem o movimento da continuação operária de empresas poderá,

${ }^{17}$ Veja-se, por exemplo, o estudo de Henrique Novaes, "Processo de Adequação Sóciotécnica nas Fábricas Recuperadas brasileiras e argentinas", publicado pela editora Expressão Popular, em 2007, com o título $O$ fetiche da tecnologia - a experiência das fábricas recuperadas. 
ao lado de outros movimentos relacionados ao campo da Economia Solidária, em que ele se situa, e dos associados à luta pela terra e pela moradia, posicionados num patamar mais alto de organização e visibilidade, ele tenderá a ser cada vez mais relevante para aqueles que lutam pelo aprofundamento do processo de democratização em curso e, para mais à frente dele, envolver-se com a construção de uma sociedade para além do capital (2013, p. $18)$.

E ele tem esse potencial porque

a existência das ERTs nos ajuda a problematizar a imprescindibilidade da organização capitalista do trabalho, da exploração do trabalho, da alienação do trabalho, das pesquisas científicas e inovações voltadas para a mercantilização de toda a vida. Elas mostram que é possível realizar mudanças no ritmo de atividades, reduzir os acidentes de trabalho, organizar a produção sem novos patrões, sem tecnocratas de direita e de esquerda, com redução da jornada de trabalho, quebrando as hierarquias e tomando decisões coletivamente. Nas ERTs surgem ações de autoorganização que questionam as estruturas de comando típicas do sociometabolismo do capital (DAGNINO \& NOVAES, 2013, p. 25)

Este é o momento para assumirmos essa pauta. A continuação operária de empresas deve ser colocada na ordem do dia da esquerda.

No século XIX, Marx mostrou com muita ironia que os patrões, os gestores, a anarquia da produção, os valores de troca e a mercadoria, enfim, o trabalho alienado são prescindíveis. Mostrou que a sociedade comunista produzirá valores de uso, de acordo com a satisfação das necessidades humanas, e cada um segundo as suas possibilidades, a cada um segundo suas necessidades. $\mathrm{O}$ autogoverno pelos produtores livremente associados substituirá a anarquia da produção, as crises periódicas e a mercantilização da vida.

Trazendo o debate para os dias de hoje, já há um certo consenso na América Latina que outro mundo é possível e que a produção associada é possível. O desafio do século XXI é transitar do possível para o necessário, tendo em vista a luta pela construção de uma sociedade para além do capital (DAGNINO \& NOVAES, 2013, p. 25-6).

A transformação desse potencial em realidade, entretanto, necessita, entre outras coisas, de estudos científicos que contribuam para o seu desenvolvimento. No campo jurídico, especificamente, fazem-se importantes estudos como o que realizamos neste trabalho, que contribuam para dar soluções à demanda jurídica que está sendo criada por este fenômeno social. As recuperações operárias estão acontecendo e nosso Estado não tem respostas estáveis para as questões que surgem delas. Como reconheceu um estudo argentino, “a questão legal atravessa todo o 
processo de recuperação de empresas" e "a busca de estratégias legais, e a capacidade de superar as lacunas e os obstáculos das leis e códigos são, em algumas circunstâncias, determinantes do êxito ou fracasso das experiências" (FAJN, 2003, p. 99-100) ${ }^{18}$. Assim, a realização de estudos jurídicos por partidários do movimento é importante não só para contribuir para a elaboração de respostas, mas, também, para que as respostas sejam adequadas e favoreçam o seu desenvolvimento. Para que as instâncias jurídicas sejam uma fonte de amparo e assistência e não de obstáculos irracionais. Há, portanto, um importante trabalho intelectual a ser realizado, inclusive no campo do direito. Por isso, a relevância desse estudo.

18 Tradução livre de: "La cuestión legal atraviesa todo el proceso de recuperación de las empresas" e "la búsqueda de estrategias legales, y la astucia para saltar los vericuetos y las trabas de las legislaciones y los códigos son, en algunas circunstancias, determinantes del éxito o fracaso de las experiencias". 


\title{
2 O DIREITO NAS TOMADAS OPERÁRIAS: LEI E LUTA DE CLASSES
}

\begin{abstract}
A ideologia dominante esforça-se para resguardar a ideia de superioridade e neutralidade do Estado e do Direito em face das contradições emergentes da vida social. Essa forma de empreender a representação ideológica do poder serve para escamotear as bases reais do edifício jurídico-político do Estado, calcado nas estruturas assimétricas e contraditórias do sistema econômico capitalista, no sentido de eliminar, ao nível da imagem, da noção comum ou do conceito teórico, as contradições que não podem ser efetivamente elididas no campo da práxis real.
\end{abstract}

Alaôr Caffé Alves (1987, p. 204)

Quinto, e talvez o mais importante reflexo negativo do custo social da atitude da executada: a acolher-se o argumento de que tudo pode ser feito para a manutenção de mil postos de trabalho, estar-se-á legitimando o desrespeito odioso das leis e jogando por terra o Estado Democrático de Direito. Imagine se a moda pega?

Trecho da sentença que decretou a intervenção na Cipla, ação no 98.01.060506/SC da $1{ }^{a}$ Vara da Fazenda Pública de Joinville/SC (MANDL, 2011)

No dia 31 de maio de 2007, uma quinta-feira, às 5 horas da manhã, a fábrica Cipla, de Joinville-SC, então a principal do Movimento de Fábricas Ocupadas, acordou em convulsão. Neste horário, os trabalhadores que lá estavam presenciaram a invasão da planta por 150 policiais federais, arregimentados para intimidar a organização operária da fábrica e impedir qualquer reação à ordem da Justiça Federal, dada dias antes, que nomeou um interventor- o Sr. Rainoldo Uessler - para assumir a fábrica e afastar a gestão operária (MANDL, 2011).

A intervenção na Cipla foi um episódio fatídico da história do controle operário da produção no Brasil, que demonstrou o quanto o direito - ou a instância jurídica, para usar a expressão mais precisa de Michel Miaille - pode atuar como obstáculo irracional à justa pretensão dos trabalhadores. 
De fato, não foi a primeira vez que operários recuperadores sofreram com decisões desfavoráveis advindas do poder judiciário. Pelo contrário. Conforme desvendou a pesquisa brasileira de ERTs concluída em 2013, o poder judiciário é o agente externo que menos fornece apoio aos trabalhadores em processos de recuperação de empresas. Atrás não somente do poder executivo e do legislativo, mas, também, por incrível que possa parecer, dos bancos e de outros empresários capitalistas (HENRIQUES et al., 2013, p.56-7).

Nesses momentos, o direito burguês retira sua máscara ideológica e, por necessidade, se transforma em explícita arma de ataque classista, assumindo publicamente sua função fundamental: servir ao funcionamento insensível do modo de produção capitalista e, portanto, à dominação da classe burguesa sobre a sociedade.

Este capítulo tem o objetivo de problematizar, em palavras breves, a atuação das instituições jurídicas junto aos conflitos econômicos e sociais que se dão entre a classe empresarial capitalista e a classe trabalhadora, demonstrando, com base nas elaborações marxistas sobre o direito, seu caráter contraditório e classista. Longe de ser o espaço da conciliação racional e neutra dos "interesses gerais" com vistas ao "bem comum", a instância jurídica é, na verdade, uma arena social conflituosa forjada na luta de classes e, portanto, em última instância, favorável aos interesses da classe dominante. 


\subsection{Direito, ideologia e dominação}

O presidente Nestór Kirchner havia se reunido com empresários espanhóis e um deles, algo indignado [com as

ocupações de fábricas na Argentina], o perguntou sobre a situação da segurança jurídica em nosso país, um eufemismo para a impunidade empresária. $\mathrm{O}$ presidente deu a resposta: "E você, que tem nove pedidos de falência na Argentina, vem me falar de insegurança jurídica?"

Jornal Página/12, 19/07/2003 (MAGNANI, 2003, p. 133)

A vida e a integridade física não têm supremacia sobre os interesses econômicos

Trecho de sentença de juiz de falências argentino em caso de recuperação operária (KLEIN, 2003, p. 15)

No século XIX, articulando os desdobramentos de sua teoria materialista dialética da história, Karl Marx escreveu, sobre o direito e o estado, que

as relações jurídicas - assim como as formas de Estado - não podem ser compreendidas nem por si mesmas, nem pela pretensa evolução geral do espírito humano, inserindo-se pelo contrário nas condições materiais de existência. [...] na produção da sua existência, os homens entram em relações determinadas, necessárias, independentes da sua vontade, relações de produção que correspondem a um dado grau de desenvolvimento das suas forças produtivas materiais. $\mathrm{O}$ conjunto dessas relações de produção constitui a estrutura económica da sociedade, a base concreta sobre a qual se ergue uma superestrutura jurídica e política e à qual correspondem determinadas formas de consciência social. O modo de produção da vida material condiciona o processo de vida social, política e intelectual em geral. Não é a consciência dos homens que determina o seu ser; inversamente, é o seu ser social que determina a sua consciência." (apud MIAILLE, 2005, p. 69).

Com este enunciado, que se tornou célebre, Marx sintetizou um de seus conceitos mais geniais, o de modo de produção. E, ao mesmo tempo, em resposta a Hegel e outros pensadores idealistas, colocou o estado e sua expressão mais importante, o direito, em uma posição menos influente no contexto da vida social humana. 
O grande crítico do capitalismo mostrou que todas as relações sociais, políticas, jurídicas e intelectuais são condicionadas pelo processo produtivo, pois é ele que permite a reprodução da vida humana. Como pontua Miaille, "Marx demonstra os mecanismos sociais numa perspectiva estrutural, mas precisando que em última análise é o nível económico que é explicativo" (2005, p. 80).

O direito e o estado vigentes desde o século XVIII, portanto, têm sua estrutura conformada pela estrutura econômica peculiar do modo de produção capitalista. A microestrutura básica desse modo de produção é a empresa capitalista, unidade produtiva cuja organização é baseada em uma divisão do trabalho hierárquica que tem, no topo, uma elite de gestores controlando o processo integral, e, abaixo, uma maioria de executores afastados (alienados) do processo integral e cumprindo tarefas elementares. Cada empresário gerencia sua unidade visando acumular capital para autoexpansão. E, globalmente, os gestores se articulam como classe (a classe burguesa, ou empresarial, ou capitalista) para organizar o processo produtivo de maneira integral, o que inclui criar estruturas políticas que permitam sua exploração econômica. Além disso, historicamente, os executores (a classe trabalhadora) também procuraram se organizar para usar sua força coletiva para impor melhoras em sua condição subalterna.

Toda a vida social, política e jurídica é organizada, no fundamental, para fazer funcionar essa mecânica produtiva peculiar. O direito e o estado vigentes, portanto, não podem deixar de ser estruturas funcionais ao modo de produção capitalista.

Ocorre que a arena econômica do capitalismo não é um espaço neutro, livre de problemas. Muito pelo contrário: a divisão do trabalho, a alienação e a tendência infinita e insensível à acumulação são fontes de conflitos gravíssimos e de sofrimento humano. Conflitos que são resolvidos não pela ação unilateral de uma classe ou de outra, mas, sim, no seio de uma luta (a luta de classes), por duas classes antagônicas. No entanto, essa luta é, fundamentalmente, sempre vencida pela classe empresarial, justamente porque ela controla e organiza os meios de produção, base da vida material de todos. Isso implica que o processo econômico é, por fim, espaço de exploração e opressão da classe trabalhadora.

Disso decorre que, como o direito e o estado são estruturas que se colocam a 
serviço do modo de produção capitalista, eles são, também, estruturas a serviço da dominação capitalista da sociedade e da exploração e opressão da classe trabalhadora. Como pontua Marilena Chauí,

\begin{abstract}
Através do Estado, a classe dominante monta um aparelho de coerção e de repressão social que lhe permite exercer o poder sobre toda a sociedade, fazendo-a submeter-se às regras políticas. $\mathrm{O}$ grande instrumento do Estado é o Direito, isto é, o estabelecimento das leis que regulam as relações sociais em proveito dos dominantes. Através do Direito, o Estado aparece como legal, ou seja, como 'Estado de direito'. O papel do Direito ou das leis é o de fazer com que a dominação não seja tida como uma violência, mas como legal, e por ser legal e não-violenta deve ser aceita. A lei é direito para o dominante e dever para o dominado. Ora, se o Estado e o Direito fossem percebidos nessa realidade real, isto é, como instrumentos para o exercício consentido da violência, evidentemente ambos não seriam respeitados, e os dominados se revoltariam. A função da ideologia consiste em impedir essa revolta fazendo com que o legal apareça para os homens como legítimo, isto é, como justo e bom. Assim, a ideologia substitui a realidade do Estado pela ideia do Estado - ou seja, a dominação de uma classe é substituída pela ideia de interesse geral encarnado pelo Estado. E substitui a realidade do Direito pela ideia do Direito - ou seja, a dominação de uma classe por meio das leis é substituída pela representação ou ideias dessas leis como legítimas, justas, boas e válidas para todos (2008, p. 86-7).
\end{abstract}

Nesse contexto, se, em um momento ou outro, o estado toma atitudes aparentemente favoráveis à classe trabalhadora e contrárias à classe burguesa, esse posicionamento apenas se constitui em estratégia de recuo necessária à manutenção do sistema. Como demonstrou o célebre teórico marxista do direito russo Poulantzas, “todas as disposições tomadas pelo Estado capitalista, mesmo as impostas pelas massas populares, são finalmente e a longo prazo inseridas numa estratégia em favor do capital ou compatível com sua reprodução ampliada" (apud OLIVEIRA, 1997, p. 214). Nesse sentido, como observa o professor Alaôr Caffé Alves, uma manobra como a consideração jurídica oficial da desigualdade de poder intrínseca à relação de emprego, que está no cerne da legislação trabalhista,

[...] faz é exatamente manter e ocultar, sob o manto da justiça social e ao nível do sistema capitalista global, a própria desigualdade real. Isso ocorre na medida em que tal consideração formal refaz de modo ideológico e operacional aquela linha de indiferença e neutralidade do Estado frente às classes ou frações de classes antagônicas, não para eliminar as desigualdades e as contradições sociais, mas precisamente para discipliná-las dentro das possibilidades daquele mesmo sistema (1987, p. 336).

Desse modo, o estado não é, como havia dito Hegel, o "Espírito Objetivo" a 
síntese coletiva e harmônica dos interesses, a "comunidade que não possui nenhum interesse particular, mas apenas os interesses comuns e gerais de todos" (CHAUÍ, 2008, p. 49). Essa síntese harmônica é, talvez, o que o estado deveria ser, no hipotético bem-querer de alguns intelectuais. Mas anunciações não mudam a realidade, por mais bem intencionados que sejam os anunciantes. Por isso, para descrever o que é o estado, em vez de fazer uma apologia sobre o que ele deve ser, seu crítico deve olhar para a realidade da vida social humana concreta.

A verdade, entretanto, é que essa visão do estado como entidade neutra, a serviço do interesse comum, é necessária para que ele cumpra sua função de instrumento de dominação. Como demonstrou Alves,

o modo de aparecer do Estado, ao mascarar as contradições sociais das quais este se origina, é a forma pela qual o próprio Estado encontra os meios de sustentação e sobrevivência legitimada, tornando possível a reprodução garantida das relações antagônicas que caracterizam o sistema social capitalista (1987, p. 17-8).

Portanto, "As relações de produção, na sociedade dominada pelo capital, pressupõem a trama ideológica não como um mero momento imaginário que pudesse aparecer após sua instauração, mas como elemento constitutivo de sua própria estrutura objetiva" (ALVES, 1987, p. 173).

No mesmo sentido, Chauí explica que

Como, porém, o Estado não poderia realizar sua função apaziguadora e reguladora da sociedade (em benefício de uma classe) se aparecesse como realização de interesses particulares, ele precisa aparecer como uma forma muito especial de dominação: uma dominação impessoal e anônima, a dominação exercida através de um mecanismo impessoal que são as leis ou o Direito Civil. Graças às leis, o Estado aparece como um poder que não pertence a ninguém. Por isso, diz Marx, em lugar de o Estado aparecer como poder social unificado, aparece como um poder desligado dos homens. Por isso, também, em lugar de ser dirigido pelos homens, aparece como um poder cuja origem e finalidade permanecem secretos e que dirige os homens (2008, p. 69-70).

O discurso de neutralidade do estado e do direito são, portanto, exemplos de discursos ideológicos, no sentido de serem "um ideário histórico, social e político que oculta a realidade", de modo que "esse ocultamento é uma forma de assegurar e manter a exploração econômica, a desigualdade social e a dominação política" (CHAUÍ, 2008, p. 7). 
Assim,

O circuito ideológico destinado a construir o instável equilíbrio das forças sociais em jogo, realizando a troca de serviços equivalentes entre dominadores e dominados, transparece por mediação o próprio Estado, que se manifesta através de um ordenamento jurídico igual para todos, através de um Direito geral e impessoal, organizador racional de instituições neutras que servem indiferentemente a todos os membros da sociedade (ALVES, 1987, p. 204).

Desse modo, podemos entender porque a atuação das instituições jurídicas junto aos conflitos sociais e econômicos que se dão entre a classe empresarial capitalista e a classe trabalhadora tem um caráter contraditório e classista.

Longe de ser o espaço da conciliação racional e neutra dos "interesses gerais" com vistas ao "bem comum", a instância jurídica é, na verdade, uma arena social conflituosa forjada na luta de classes e, portanto, em última instância, favorável aos interesses da classe empresarial capitalista.

\subsection{Ainda precisamos conhecer os mecanismos jurídicos}

$\mathrm{Na}$ trajetória das tomadas operárias brasileiras, em inúmeros momentos a instância jurídica foi fonte de problemas. No entanto, é verdade, também, que os trabalhadores tiveram êxito em muitas batalhas travadas nesta arena. Ou seja: ao mesmo tempo em que a instância jurídica burguesa atuou, em geral, como obstáculo contrário à aspiração dos trabalhadores, também serviu como instrumento para realizações essenciais.

Há uma contradição. E o direito é, de fato, contraditório, simplesmente porque, como vimos, sua fonte não é nenhum "espírito objetivo puro", mas sim a luta de classes que acontece na arena econômica e social.

É certo, portanto, que o direito em vigência nunca atuará, no fundamental, em favor da classe trabalhadora na parte de seus interesses que são contrários à 
classe empresarial dominante. No entanto, isso não é motivo para ignorarmos, como combatentes da classe trabalhadora, os mecanismos e o discurso jurídicos oficiais. Na verdade, pelo contrário: é obrigatório conhecê-los.

Isso porque, enquanto ele estiver em vigor, suas questões se colocarão em nosso caminho. E é nosso papel elaborar formulações jurídicas progressistas para lidar com elas e, caso a caso, superá-las, visando o objetivo maior, que é permitir o desenvolvimento desse movimento de potencial revolucionário: a continuação operária de empresas.

Não há outra via. Não é possível transformar a instância jurídica global antes para, depois, começar a desenvolver as experiências econômicas. O caminho materialista histórico dialético é o inverso: batalhar, inicialmente sob a vigência da instância jurídica burguesa, para forçar o reconhecimento e a aceitação das experiências de controle operário.

Por essa razão, a partir do próximo capítulo passaremos a nos dedicar a enfrentar algumas das questões jurídicas que se colocam na longa e árdua trajetória que percorrem os recuperadores de empresas. 


\title{
3 MIRANDO AS QUESTÕES JURÍDICAS: SOLUÇÕES FAVORÁVEIS A PARTIR DA CONSTITUIÇÃO DE 88
}

\author{
Em termos dogmáticos, se a Constituição prevê os \\ mecanismos para sua efetivação, por que as reivindicações de \\ reforma agrária são tratadas como questões possessórias ou \\ policiais, ou seja, apenas nos quadrantes do Direito Civil e do \\ Direito Penal? \\ Tarso de Melo (2009, p. 21)
}

Os coletivos de trabalhadores brasileiros que, nos dias de hoje, resolvem assumir empresas falidas de seus patrões enfrentam um grande problema: a carência de respostas estáveis, favoráveis e eficazes às questões jurídicas que surgem no desenrolar de sua empreitada. Os agentes estatais da instância jurídica, até o momento, têm, na maioria das vezes, favorecido os empresários tradicionais capitalistas e embaraçado ou ignorado os interesses dos trabalhadores autoorganizados.

Como já dissemos, questões jurídicas se colocam ao longo de todo o processo de recuperação de empresas e são, muitas vezes, determinantes de seu êxito ou fracasso. Os trabalhadores, portanto, necessitam que o estado responda de forma favorável a sua intenção de recuperação. Conforme desvendaram os mapeadores das ERTs brasileiras,

[...] a conquista de um marco legal e, em geral, a promoção de políticas públicas que considerem a especificidade das ERTs, que sejam menos adversas em relação às iniciativas de recuperação de empresas, que permitam o acesso a crédito governamental, são vistas por uma parcela significativa das empresas pesquisadas como uma condição para reverter o que consideram um posicionamento contrário do Estado em relação a elas. [...] a regra para o acesso a crédito e fomento continua sendo a exigência de condições e garantias equivalentes às de empresas privadas capitalistas, ou pior nos casos de processos falimentares não concluídos. Além disso, a maioria das ERTs (cerca de 60\%) relata não ter recebido nem receber apoio do Estado para a recuperação e manutenção da empresa, e com isso, tem uma avaliação negativa do Estado (70\%) (HENRIQUES et al., 2013, p. 210). 
A carência de respostas estatais adequadas, portanto, é patente.

Em nosso estudo sobre as experiências brasileiras de recuperação, empreendemos a difícil tarefa de tentar identificar e categorizar essas questões, o que é necessário para que se possa entendê-las e enfrentá-las, contribuindo para o desenvolvimento das experiências atuais e futuras. A empreitada resultou na identificação de quatro problemáticas centrais: a) a licitude da greve de ocupação; b) a necessidade de reconhecimento da gestão operária no procedimento de falência e recuperação empresarial; c) a necessidade, em médio e longo prazo, de estabilização jurídica do ente coletivo, por meio da constituição de uma forma jurídica adequada; e d) a carência, em geral, de outras políticas públicas específicas, especialmente as que possibilitem o acesso a crédito ${ }^{19}$.

Pensando nas problemáticas elencadas, para este estudo selecionamos dois focos principais.

Em primeiro lugar, demonstrar qual é o conteúdo e a abrangência e quais são os efeitos dos três princípios constitucionais que podem servir de base positiva fundamental para o enfrentamento de todas essas questões: o princípio do direito ao trabalho (artigo $6^{\circ}$ ), o princípio do valor social do trabalho e da livre iniciativa (artigo $1^{\circ}$, IV, e 170, caput) e o princípio da função social da propriedade dos bens de produção (artigo 170, III).

Em segundo lugar, propor solução, a partir de um confronto com os princípios da Constituição à luz da Teoria dos Direitos Fundamentais, para a primeira questão, a da licitude da greve de ocupação - e, em especial, da greve de ocupação ativa, que se dá com o objetivo de produzir.

\footnotetext{
${ }^{19}$ É importante não ignorar o quanto são diversas as situações e questões emergentes nos casos de ERT. Cada experiência tem suas próprias características e seus próprios problemas. Algumas se iniciam com uma ocupação forçada, outras com uma autorização judicial; algumas se constituem em uma forma jurídica privada, outras reivindicam a estatização; algumas se iniciam em meio ao um processo judicial de falência da empresa original, mas em outras nem há um processo de falência e a tomada se dá após negociação direta com o antigo proprietário. Trata-se, portanto, de um universo bastante heterogêneo, não é fácil estabelecer padrões. Entretanto essa categorização é necessária, se queremos compreender os problemas existentes e usar as experiências passadas para seguir em frente.
} 


\subsection{Prólogo: opção metodológica alexyana e base sociológica marxista}

Ante de iniciar nossa análise, faremos um breve esclarecimento acerca de nossa opção metodológica para o enfrentamento jurídico que empreendemos neste capítulo.

Somos partidários, como se verificou nos capítulos anteriores, da visão teórica marxista de compreensão da estrutura social, política e jurídica. No entanto, para o enfrentamento das questões jurídicas emergentes dos casos de recuperação operária de empresas, que ocupará este capítulo, nos sustentamos em proposições metodológicas inseridas no ideário do pós-positivismo. Em especial, a Teoria dos Direitos Fundamentais de Robert Alexy. Proposições que, por certo, não têm base marxista.

Entendemos a virtual contradição, mas frisamos que se trata de uma opção consciente.

Ocorre que este trabalho tem um objetivo principal muito claro: contribuir na prática para as recuperações operárias atuais e futuras, fornecendo fundamentos jurídicos para suas ações e seus requerimentos perante os órgãos estatais. A todo momento os recuperadores se vêm diante de problemas que a instância jurídica burguesa os coloca e, atualmente, carecem de fundamentos para enfrentá-las.

Para termos chances reais alcançarmos este objetivo - de modo que nossos fundamentos cheguem a serem utilizados, por exemplo, em decisões judiciais -, é importante que nossa análise, além de intelectualmente bem elaborada, seja fundamentada em métodos prestigiados pelos agentes jurídicos oficiais.

Nesse sentido, as proposições de teóricos como Alexy, Canotilho e Barroso atendem bem a esses requisitos. Além de permitirem uma construção intelectualmente elaborada, elas têm razoável aceitação nos meios acadêmicos e oficiais. A teoria alexyana, em especial - que utilizaremos para o complexo exame da licitude da greve ativa - é respeitada internacionalmente e, ainda, fornece um parâmetro metodológico estruturado que permite um debate racionalizado sobre 
problemas jurídicos complexos.

Fundamentando nossas conclusões nessas teorias, entendemos que temos maiores chances de êxito no alcance de nosso objetivo principal. Essa a razão, portanto, para nossa opção metodológica.

3.2 Três suportes para todos os enfrentamentos: os princípios constitucionais da função social da propriedade, do direito ao trabalho e do valor social do trabalho e da livre iniciativa

Há três preceitos da Constituição de 1988 que têm papel central na análise que desenvolveremos. Isso porque são, direta ou indiretamente, suportes para o enfrentamento, pela perspectiva dos trabalhadores, de todas as problemáticas que identificamos em relação à ocupação de fábricas falidas. Por isso, antes de debruçarmo-nos sobre elas, faremos uma abordagem desses três preceitos, explicitando seu conteúdo e demonstrando que são aplicáveis aos casos concretos de recuperação operária. Trata-se dos princípios: da função social da propriedade (artigo $5^{\circ}$, XXIII, e 170, III); do direito ao trabalho (artigo $6^{\circ}$ ) e do valor social do trabalho e da livre iniciativa (artigo $1^{\circ}$, IV, e 170, caput).

\subsubsection{Conteúdo jurídico e abrangência dos três suportes constitucionais}

Esses três princípios são centrais porque correspondem aos valores jurídicos basilares que estão por trás dos conflitos que emergem dos processos de recuperação operária. 
Em todo contexto de continuação operária de empresas, o embate se dá fundamentalmente entre três interesses. De um lado, o interesse dos trabalhadores, que dependem do trabalho para seu sustento e que, por isso, não querem que a empresa encerre suas atividades, querem continuar trabalhando. De outro, o interesse do proprietário da empresa em crise, que calcula o acontecimento em termos de lucro-prejuízo e quer perder o menos possível; por isso, procura, na maior medida possível, transformar o patrimônio em crise (em especial, o maquinário da empresa) em algo lucrativo (às vezes, tentando voltar a controlar o empreendimento, e, às vezes, tentando vendê-lo total ou parcialmente). E, por último, o interesse dos credores - principalmente governos e bancos - que querem receber o pagamento de suas dívidas.

Analisando esse contexto, podemos verificar que, em última instância, há apenas três valores jurídicos em embate: a propriedade (empresário em crise, credores e trabalhadores), o trabalho (trabalhadores) e a livre iniciativa econômica (trabalhadores, empresário e credores não-estatais). Todos os conflitos concretos da trajetória de uma ERT podem ser traduzidos como tentativas, pelos envolvidos, de fazer valer um desses valores sobre os outros ${ }^{20}$.

Os trabalhadores, por exemplo, defendem seu intento de continuar a empresa com os argumentos de que é daquele trabalho que advém seu sustento e de suas famílias (valor trabalho), que a atividade produz bens de consumo necessários para quem os compra e isso movimenta a economia, gerando emprego e renda para além das famílias diretamente envolvidas (valor livre iniciativa econômica), e, além disso, que o empresário não honrou seus deveres trabalhistas e possui um débito com eles (valor propriedade). O empresário em crise, por sua vez, argumenta que deve ser valorizado por ter se arriscado e investido em uma atividade econômica que movimentou a economia (valor livre iniciativa econômica), e, além disso, a empresa é seu patrimônio e a propriedade deve ser protegida pelo direito, pois apenas assim os empreendedores terão segurança para investir e, com isso, beneficiar a todos com a movimentação da economia (valor propriedade). E, por fim, os credores não-

\footnotetext{
${ }^{20}$ Há, na verdade, um quarto valor importante que aparece nesses embates, o da justiça fiscal, encampado exclusivamente pelos credores estatais (governos municipais, estaduais e federal, INSS etc.). Ele corresponde à ideia de que a arrecadação tributária é importante porque se reverte em benefícios para toda a sociedade. Não o incluímos neste momento porque ele não tem papel central no enfrentamento das questões jurídicas pela perspectiva dos trabalhadores.
} 
estatais arguem que as dívidas foram contraídas em negociações contratuais feitas no mercado e uma economia saudável precisa que essas negociações sejam protegidas para que os agentes econômicos tenham segurança para empreender (valor livre iniciativa econômica); e, além disso, que a dívida existe e deve ser paga, sob pena de enriquecimento ilícito por um lado e prejuízo injustificado do outro (valor propriedade) ${ }^{21}$.

Ora, qual desses argumentos deve prevalecer em cada conflito, segundo a ordem jurídica instituída? Ou seja, qual é o tratamento dado pela legislação a cada um desses valores? A resposta está justamente no conteúdo normativo desses três princípios da Constituição e que dão fundamento jurídico positivo aos argumentos desses três agentes. Daí a importância de conhecê-los.

O princípio do valor social do trabalho e da livre iniciativa está posicionado no artigo $1^{\circ}$, IV, e no 170 , caput, da Constituição. Indicada como fundamento da república pelo constituinte de 88 , esta norma reflete a presença da ideologia do Estado Social, inspirado na socialdemocracia europeia, no contexto da redemocratização brasileira. A norma, por um lado, prestigia a fórmula liberal da livre iniciativa econômica, que significa, ideologicamente, que qualquer um pode iniciar um empreendimento econômico independentemente de autorização estatal e, além disso, que quem o fizer, arriscando seu patrimônio, deve ser valorizado por isso - definindo, na prática, que a economia brasileira funcionaria em um sistema de mercado capitalista, distanciando o país dos modelos de economia estatal, já em absoluta decadência quando da elaboração do texto constitucional. Mas, por outro, concilia-a com uma referência ao valor social do trabalho, indicando, em suma, que o papel econômico do trabalhador subordinado também deve ser valorizado, e, portanto, que a classe trabalhadora não deve ser totalmente deixada à mercê do mercado capitalista, pois deve receber a proteção estatal por meio do reconhecimento de direitos sociais. Isso significa que este inciso do artigo $1^{\circ}$, em sua significação jurídica tradicional, é claramente dividido em duas partes: uma que se dirige claramente à classe empresarial capitalista, e a outra à classe trabalhadora assalariada. No entanto, isso não implica a impossibilidade de novas interpretações em decorrência da confrontação com novos contextos. Queremos dizer que se, no

${ }^{21}$ É interessante perceber que o valor da livre iniciativa econômica aparece, neste embate, também ao lado dos trabalhadores, além dos empresários; o que não ocorre, de maneira alguma, nos embates tradicionais entre capital e trabalho, nos quais esses últimos se colocam apenas como empregados. 
contexto das tomadas operárias de empresas, os trabalhadores em coletivo desejam tomar para si o controle de uma atividade econômica, assumindo seus riscos, nada impede que se considere esse intento como iniciativa econômica e, portanto, como expressão do princípio da valorização da livre iniciativa. E, ao mesmo tempo, tendo em vista que a empresa será coletiva e não haverá empregados, mas apenas trabalhadores-patrões, tem-se uma expressão do princípio do valor social do trabalho. De qualquer maneira, esse dispositivo apresenta, em linhas gerais e dogmáticas, este conteúdo: valoriza e garante a liberdade capitalista (de empreender e explorar na arena econômica) e o risco empresarial, ao mesmo tempo em que valoriza o papel do trabalhador e promete proteção estatal para a classe trabalhadora.

O princípio do direito ao trabalho, por sua vez, está previsto no artigo $6^{\circ}$ da Carta, que o coloca como um direito social. O reconhecimento do direito ao trabalho como tal também é derivação do ideário tradicional dos direitos humanos, e constou nas clássicas declarações humanitárias (da Revolução Francesa, de 1789, e da ONU, de 1948). O direito ao trabalho é a base fundamental de garantia dos direitos sociais, pois, para a quase totalidade da população - a classe trabalhadora - 0 trabalho é a única via de acesso aos demais direitos (a educação, a saúde, a alimentação, a moradia, o lazer, a segurança, a previdência social, e a proteção à maternidade e à infância, para mencionar apenas os direitos sociais expressos no artigo $6^{\circ}$ da CF). É o que reconheceu a Assembleia Geral da ONU, na Resolução n. ${ }^{\circ}$ 34/46, de 1979: "a fim de garantir cabalmente os direitos humanos e a plena dignidade pessoal, é necessário garantir o direito ao trabalho". Eis, portanto, o significado jurídico desse princípio: o reconhecimento de que a população precisa de trabalho para viver e gozar de direitos, e, com ele, a promessa de que o estado deverá agir junto à economia no sentido de garantir trabalho digno para todos 22 .

\footnotetext{
${ }^{22}$ É claro que, tendo conhecimento das precisas explicações marxistas acerca do funcionamento da vida em sociedade e, em especial, da vida no sistema social capitalista, sabemos o quanto são limitadas as possibilidades de atuação do estado neste campo. Se olharmos para o "rico" sudeste brasileiro, por exemplo, veremos que as 63 milhões de pessoas em idade de trabalhar que moram nessa região se inserem numa cruel pirâmide de divisão desigual do trabalho, de modo que apenas 21 milhões (34\%) têm o privilégio de ter trabalhos formais, e 7 milhões (11\%) diploma de ensino superior, enquanto, na base, 25 milhões (40\%) sequer concluiu o ensino fundamental (fontes: Censo IBGE Resultados Gerais da Amostra 2010 e GFIP 2011). Essa pirâmide é característica fundamental da sociedade capitalista. Explicamos: como na economia capitalista a maioria das pessoas - a classe trabalhadora - é responsável por executar funções elementares em seu trabalho e está distanciada do trabalho intelectual de controle e gestão da atividade produtiva (nas palavras de Marx, está em posição alienada), seu trabalho é desestimulante; por isso, um motor fundamental de impulso do trabalho do assalariado - e, portanto, um motor fundamental de todo o processo produtivo no modo de produção
} 
Por último, temos o princípio da função social da propriedade, que, a nosso ver, é o mais denso, complexo e controverso dos três. Ao mesmo tempo, provavelmente, é a mais efetiva e importante arma constitucional para os embates jurídicos encarados pelos recuperadores.

Este princípio aparece duas vezes na Constituição brasileira de 88: no inciso XXIII do artigo $5^{\circ}$ e no inciso III do artigo 170. A duplicidade, como esclareceu Eros Grau em sua análise da ordem econômica constitucional (2010, p. 252), tem uma razão clara: o constituinte frisou que a ordem constitucional reconhece dois tipos diferentes de propriedade: a de bens de consumo (artigo $5^{\circ}$, posicionado no capítulo dos direitos fundamentais) e a de bens de produção (artigo 170, posicionado no capítulo da ordem econômica). E, ao mesmo tempo, reconhece uma função social diversa para a propriedade de cada um desses bens. A classificação se dá, portanto, como esclareceu Fábio Konder Comparato, segundo a destinação do bem (1986, p. 77). A nós interessa, neste momento, apenas esta segunda categoria - bens de produção -, pois é sempre a que entra em questão nos casos de recuperação operária.

O direito de propriedade, como se sabe, é instituto basilar do direito burguês. A razão disso já foi explicada neste trabalho: a instância jurídica é

capitalista - é a ameaça de desemprego (e, com ela, do fim da fonte de sustento). Então, o funcionamento desse modo de produção necessita de um sistema de mercado de reserva humana (que Marx chamou de exército de reserva) que garanta ao empresário capitalista uma razoável liberdade para dispensar qualquer empregado e substituí-lo por outro disponível, de acordo com sua conveniência. Disso decorre que o acesso ao trabalho na economia capitalista se dá na forma de uma grande pirâmide de divisão desigual do trabalho, com cada ocupado temeroso de que sua posição seja assumida por quem está abaixo. Como isso funciona do diretor de fábrica ao catador de lixo, a base dessa pirâmide (que, no caso do sudeste brasileiro, corresponde aos 40\% que não concluíram os estudos fundamentais) é uma reprodução cruel, porque real, do inferno na terra. Quem controla essa pirâmide humana e a mantém dimensionada segundo a necessidade do sistema é a classe empresarial, que detém o controle do processo produtivo global justamente porque o organiza e gerencia do âmbito micro (cada empresa) ao macro. Organiza-a assim não exatamente porque quer, porque é "má por natureza", mas porque o sistema exige. O estado é absolutamente incapaz de fazer grandes transformações nessa realidade. $\mathrm{Na}$ verdade, não tem sentido pensar em um estado que ignore as ordens da classe burguesa e transforme a realidade contra seus interesses, porque, de fato, $o$ fundamento de existência do estado que existe é justamente executar essas ordens; ele é o braço executor mais importante da classe burguesa. Por isso, quando intervém, o faz ou executando os comandos dessa classe (por exemplo, quando abre escolas de ensino superior para fazer frente ao aumento populacional, ou ao deslocamento para cima da economia local na pirâmide mundial de divisão do trabalho) ou, no limite, com seu aval (por exemplo, com programas de assistência como o "Bolsa Família", que fornece uma renda mensal de valor miserável para a população da base, valor que, por não ser suficiente para fazer a pessoa desistir de procurar os trabalhos mais mal remunerados, não atrapalha o funcionamento da pirâmide). Essa é a realidade da limitação da ação do estado na garantia do acesso ao trabalho, uma limitação absoluta, profundamente vigorosa, que deixa uma margem de manobra pequena. Entretanto, não é o caso de considerarmos, neste momento, esta condição material, pois estamos apenas tratando do conteúdo normativo do princípio do direito ao trabalho, com o intuito de usá-lo como instrumento para defender as recuperações operárias (essas, sim, com potencial transformador real). 
condicionada pelo modo de produção - pois serve, no fundo, para permitir sua realização (MIAILLE, 2005, p. 96) - e o modo de produção capitalista necessita, em especial, de um direito que favoreça e proteja a exploração empresarial capitalista. Para isso, entre outras coisas, esse direito deve garantir proteção privilegiada à propriedade, pois apenas assim o capitalista terá segurança para explorar atividades econômicas a seu modo (agressivo). Como pondera Tarso de Melo, “o capitalismo [...] depende profundamente da noção de propriedade para existir. Não à toa, o Direito surgido na União Soviética após a revolução tinha seu principal traço distintivo no tocante à propriedade" (2005, p. 57). É por isso que

\begin{abstract}
A propriedade, como visão de mundo e instituto jurídico, está 'no centro do projeto' desde a Revolução Francesa, a partir da qual é a propriedade que vai definir as classes sociais; ela estava entre as principais bandeiras dos revolucionários, tanto que posteriormente o Code civil de 1804 se tornaria a 'Bíblia da burguesia' (MELO, 2005, p. 60; citando Barcellona, Solari e Stucka).
\end{abstract}

Desde o início do século XX, entretanto, houve uma "mudança de tom” (a expressão é de Melo) no discurso jurídico sobre a propriedade.

Suas primeiras elaborações dogmáticas se deram nas vozes de Otto von Gierke (Die soziale Aufgabe des Privatrecht, 1889), Karl Renner (Die soziale Funktion des Rechtsinstitute, 1904) e Leon Duguit (Les transformations générales Du droit privé depuis le Code Napoléon, 1912) (MELO, 2005, p. 67). E sua primeira materialização positiva se deu pelo artigo 153 da Constituição de Weimar, de 1919, a primeira Constituição Republicana Alemã, que inaugurou, no patamar constitucional, a previsão da funcionalização social da propriedade. $O$ dispositivo previa: “ $A$ propriedade obriga. Seu uso deve, ao mesmo tempo, servir o interesse da coletividade" (COMPARATO, 1986, p. 75) ${ }^{23}$.

A mensagem emitida por essa mudança discursiva é clara: a propriedade não deve mais ser encarada como um instituto merecedor de proteção absoluta, pois seu reconhecimento está condicionado ao cumprimento de determinada função social. Ficou conhecida a formulação de Duguit:

Todo indivíduo tem a obrigação de cumprir na sociedade uma certa função, na razão direta do lugar que nela ocupa. Ora, o detentor da riqueza, pelo próprio fato de deter a riqueza, pode cumprir uma

\footnotetext{
${ }^{23}$ Original alemão: "Eigentum verpflichtet. Sein Gebrauch soll augleich der Wohle der Allegemeinheit dienen" (COMPARATO, 1986, p. 75).
} 
certa missão que só ele pode cumprir. Somente ele pode aumentar a riqueza geral, assegurar a satisfação de necessidades gerais, fazendo valer o capital que detém. Está, em consequência, socialmente obrigado a cumprir esta missão e só será socialmente protegido se cumpri-la e na medida em que o fizer. A propriedade não é mais o direito subjetivo do proprietário; é a função social do detentor da riqueza (apud RIBEIRO, 2003, p. 19).

Essa, em síntese, é a origem desse princípio da carta constitucional brasileira $^{24}$.

O significado do princípio da função social da propriedade, portanto, é muito maior, como pontua Comparato, que a mera imposição de restrições (ambientais, por exemplo) ao uso e gozo dos bens próprios (1986, p. 75).

Este princípio implica que a propriedade é um poder-dever imposto a seu titular, dever esse de dar ao objeto da propriedade destino correspondente ao interesse coletivo, e não ao interesse próprio, sob pena de sanção pela ordem jurídica (COMPARATO, 1986, p. 75).

Há uma pequena especificidade quando se trata de bens de produção. Nesses casos, a pessoa obrigada a cumprir o poder-dever não é, exatamente, o proprietário, mas sim o administrador, gestor ou controlador da atividade empresarial. Isso porque, quando os bens acham-se incorporados a uma exploração empresarial, "a relação de propriedade [...] transmuda-se [...] em poder de controle, isto é, na prerrogativa de comando e direção como um todo, compreendendo pessoas e bens". E, por isso, "a discutida função social já não é um poder-dever do

\footnotetext{
${ }^{24}$ Vale esclarecer, como fizemos com relação ao princípio do direito ao trabalho, que temos ciência das limitações reais dessa declarada "funcionalização social" do direito de propriedade burguês. Essa limitação sempre rendeu críticas severas de teóricos da esquerda a esse discurso, e, entre elas, talvez a mais aguda tenha sido a do célebre jurista marxista russo Pasukanis, que afirmou, com coerência, que "a apresentação do direito de propriedade burguês como uma obrigação social não passa de uma hipocrisia", e "a burguesia [...] somente tolera tais considerações acerca das funções sociais da propriedade porque elas não a comprometem em nada" (apud MELO, 2005, p. 67-8). A crítica é, de fato, intocável. Assim, é equivocado acreditar que, a partir da iniciativa dos órgãos estatais e jurídicos, essa declaração constitucional da funcionalização da propriedade privada irá resultar em alguma transformação fundamental. Nas mãos da burguesia, a função social da propriedade é puro discurso ideológico, que engana e alicia a classe trabalhadora. Entretanto, é claro que isso não significa que essa classe não pode, em suas ações materiais organizadas com vistas a certa transformação real no mundo econômico, lançar mão desse discurso da ideologia burguesa para defender, nos casos concretos, suas próprias ações socializantes.
} 
proprietário, mas do controlador" e seu conteúdo corresponde a "dirigir a empresa para a realização dos interesses coletivos" (1986, p. 76-8).

E qual é a consequência do não cumprimento desse dever?

Ora, se a funcionalização social se integra, de fato, ao conteúdo do instituto da propriedade, então a única consequência possível para o descumprimento desse dever é o esvaziamento do direito subjetivo de propriedade com relação ao titular descumpridor, e, consequentemente, seu desamparo jurídico. É nesse sentido a conclusão de Grau, segundo o qual "a propriedade dotada de função social é justificada pelos seus fins, seus serviços, sua função" e, por isso, "o princípio da função social da propriedade passa a integrar o conceito jurídico-positivo de propriedade [...]. Em razão disso - pontualizo - é justamente sua função que justifica e legitima essa propriedade" (2010, p. 244 e 251). Sendo assim,

a propriedade dotada de função social, que não esteja a cumpri-la, já não será mais objeto de proteção jurídica. Ou seja, já não haverá mais fundamento jurídico a atribuir direito de propriedade ao titular do bem (propriedade) que não está a cumprir sua função social (GRAU, 2010, p. 344, grifo nosso).

Também é a posição, entre outros, de Pietro Perlingieri, que defende: "a ausência de atuação da função social, portanto, faz com que falte a razão da garantia e do reconhecimento do direito de propriedade" (apud MELO, 2005, p. 71). A garantia da propriedade pela instância jurídica, portanto, fica sujeita se expirar, falecer, com a violação de sua função social.

Assim, temos o conteúdo do importantíssimo princípio do artigo 170, III, da Constituição. Por influência desse princípio, o proprietário de bens de produção - de uma planta fabril, por exemplo - passa a ter um "poder-dever" (Comparato) ou uma “propriedade-função social” (Grau) e fica obrigado a manejar esses bens não apenas segundo interesses próprios, mas também levando em conta os interesses da coletividade. E a consequência para o descumprimento dessa obrigação é o esvaziamento do direito e a sujeição ao desaparecimento de sua proteção pelas instituições jurídicas.

Diante disso, é possível entender por que esse princípio constitucional é tão relevante para os operários recuperadores.

A questão é que é muito recorrente, nesses contextos, que os empresários 
capitalistas tenham cometido atos gravemente antissociais - e, com muita frequência, ilegais - para evitar prejuízos ao seu próprio patrimônio. Atos que visam preservar sua própria riqueza, independentemente de consequências lesivas a outros (e, em especial, aos mais vulneráveis, os trabalhadores). E, ao mesmo tempo e na outra ponta, é frequente que os coletivos operários argumentem que são uma melhor opção social de manejamento da empresa, tendo em vista que o fim último de sua gestão não será o desumano "lucrar mais para lucrar mais"; o empreendimento trará mais benefícios à comunidade local (e à sociedade como um todo) do que trazia enquanto nas mãos do capitalista. O tema da função social da empresa, portanto, naturalmente já se faz presente nos embates de tomada operária.

Retornando aos atos dos capitalistas em crise, de fato, quando prognosticam uma crise no futuro de sua empresa, com frequência, os patrões praticam ações fraudulentas, como venda oculta de maquinário, transferência acionária para sócios "laranjas", nomeação de administradores especializados em falências fraudulentas, sonegação de impostos, calote em salários e benefícios trabalhistas como FGTS e contribuição previdenciária etc. Vários desses atos fraudulentos são apontados pelos trabalhadores de ERTs como desencadeadores das tomadas operárias (HENRIQUES et al., 2013, p. 46-7). Essa postura faz parte, na verdade, da cultura empresarial capitalista de exploração agressiva e egoísta dos recursos da terra e do suor da classe trabalhadora; e, a propósito, os maiores especialistas em manejá-la são justamente os advogados empresariais.

O empresário está cumprindo seu poder-dever social quando pratica esses atos? Ora, é claro que não. Nesses casos, o empresário afeta violentamente essa função que a lei brasileira lhe impõe. Há claro abuso do direito de propriedade.

Podemos dizer, em desenvolvimento à elaboração teórica acerca da função social da propriedade, que há descumprimento do poder-dever da propriedade em dois casos: quando o controlador da empresa pratica atos empresariais gravemente ilegais e quando pratica atos empresariais gravemente antissociais.

Atos empresariais gravemente ilegais são aqueles de desrespeito direto, claro e socialmente grave da legislação. Como, por exemplo, sonegação de impostos, inadimplemento grave de direitos trabalhistas, atentados graves à saúde ou à segurança dos trabalhadores, fraude contra credores e outros crimes falimentares (Lei 
n. 11.101/05), crimes ambientais (Lei n. 9.608/98), crimes contra a propriedade intelectual (Lei n. 9.279/96) e outros crimes empresariais. Atos empresariais gravemente antissociais, por sua vez, são aqueles que não constituem, a princípio, uma violação direta à lei, mas refletem um posicionamento egoísta do empresário em prejuízo de interesses coletivos, com grave rompimento da responsabilidade decorrente de sua posição econômica e social. Podemos citar, como exemplos, a alienação de quotas da sociedade com nomeação de sócios incapazes de administrar ou insolventes, ou o fechamento de uma planta fabril lucrativa para abertura de outra em benefício exclusivo dos empresários (por exemplo, uma nova planta que explore mão de obra apenas em contratação precária ${ }^{25}$ ). $\mathrm{O}$ critério deverá ser, para cada caso concreto, a confrontação dos interesses individuais e coletivos que estão sendo favorecidos e prejudicados. Se os interesses individuais dos empresários forem favorecidos em prejuízo dos interesses do coletivo de trabalhadores e suas famílias ou da comunidade local, sem correspondente compensação em benefício de outros interesses coletivos, então o ato se constituirá como uma violação ao poder-dever social da propriedade. Em síntese, atos que implicam numa violação grave às responsabilidades sociais estabelecidas pela ordem jurídica para o controlador de bens de produção.

E a consequência jurídica disso não será outra senão o desaparecimento da proteção jurídica da propriedade com relação ao empresário capitalista, desaparecimento que se tornará relevante somente em determinado contexto concreto: quando houver um conflito, no mundo fora dos códigos, cujo teor seja a questão de quem detém, legitimamente, o controle da empresa e de seus bens de produção. Esse contexto aparece, por exemplo, nos casos de continuação operária e, também, nas ocupações de terra improdutiva feita por trabalhadores rurais.

\footnotetext{
${ }^{25}$ Como ocorreu, por exemplo, no caso recente euamericano, a New Era Windows. Como narram os recuperadores, "em 2008, depois de muitas décadas de operação, a Republic Windows and Doors foi à falência e fechou. O que era estranho, pois o negócio de janelas parecia lucrativo. Ao mesmo tempo, negócios da família proprietária abriram novas fábricas em Chicago, contratando trabalhadores por meio de agências de trabalho temporário. Eles também estavam sendo investigados pelas autoridades por irregularidades na falência e foram processados por bancos por dívidas pendentes. Parecia que a razão para os trabalhadores perderem seus empregos não era que não estavam realizando um trabalho lucrativo" (NEW ERA WINDOWS COOPERATIVE, 2013). Tradução livre de: "In 2008, after many decades of operation, Republic Windows and Doors went bankrupt and was shut down. This seemed odd as the windows business appeared profitable. Meanwhile, members of the family business opened new windows factories in Chicago, hiring workers through temp agencies. They were also investigated by authorities over irregularities in their bankruptcy and were sued by banks over outstanding debts. It seemed the reason workers were losing their jobs might not be because they weren't doing profitable work".
} 
Voltando às recuperações operárias, podemos desenhar a seguinte conclusão, pensada especialmente para esse contexto: em decorrência do princípio da função social da propriedade de bens de produção, assentado no artigo 170, III, da Constituição, sempre que um empresário em crise houver praticado atos ilegais ou antissociais (que prejudiquem interesses coletivos em favorecimento de interesses egoístas), a proteção jurídica de sua propriedade ficará sujeita a desaparecer, o que efetivamente se concretizará se os trabalhadores desafiarem seu controle efetivo da atividade produtiva e sua legitimidade, manifestando a intenção de continuar a empresa coletivamente. Em outras palavras, a prática de atos empresariais ilegais ou antissociais abre, para o coletivo operário, o caminho para assunção juridicamente legítima da atividade ${ }^{26}$.

Esses são, por fim, os três princípios constitucionais que têm relação fundamental com as questões jurídicas que emergem nos processos de recuperação operária: o princípio da função social da propriedade, o princípio do valor social do trabalho e da livre iniciativa e o princípio do direito ao trabalho. Pela centralidade e potencialidade, esses dispositivos devem ser explorados ao máximo pelos coletivos operários nos enfrentamentos jurídicos do processo de recuperação. Sua utilização inteligente pode contribuir para conquistas importantes nos embates judiciais e na criação legislativa.

\footnotetext{
${ }^{26}$ Um esclarecimento importante. A nosso ver, como se vê, a questão da proteção jurídica da propriedade antissocial só ganha relevância em contextos de conflitos concretos nos quais ela é questionada. Assim, não entendemos que a prática de atos empresariais ilegais ou antissociais devam implicar em qualquer reação de iniciativa unilateral de órgãos de estado no sentido de materializar o desaparecimento da proteção da propriedade. Por exemplo, a ideia de uma "lei" de expropriação de empresários violadores do princípio em favor de trabalhadores que sequer se auto-organizaram e não demonstraram intenção alguma de assumir a atividade. Nossa intenção é fugir de elaborações jurídicas idealistas e formalistas, que vejam ingenuamente formulações dogmáticas, ideias legislativas sem base real ou ações estatais puras como caminho para qualquer transformação social relevante. A realidade social é fundamentalmente econômica e está aí, se movimentando com força pujante, e é uma grande ilusão imaginar que o estado ou o direito podem domesticá-la. Sua transformação fundamental só poderá ser feita pela classe trabalhadora organizada, igualitariamente, na luta real pelo controle da produção.
} 


\subsubsection{Pós-positivismo e efetividade dos princípios constitucionais}

Toda norma constitucional é dotada de eficácia jurídica e deve ser interpretada e aplicada em busca de sua máxima efetividade.

No seu conjunto, regras e princípios constitucionais valem como "lei": o direito constitucional é direito positivo. Nesse sentido se fala na "constituição como norma" (Garcia de Enterria) e na "força normativa da constituição" (K. Hesse).

Joaquim Canotilho (2003, p. 1176)

Tratamos, neste tópico, de desenvolver teoricamente o conteúdo dos três princípios constitucionais importantes para as questões jurídicas das continuações operárias. Essa elaboração, entretanto, se deu com o pressuposto de que os princípios da Constituição têm efeitos jurídicos imediatos a casos concretos.

Esse pressuposto merece ser comentado, pois, na verdade, se constitui numa conclusão do ideário pós-positivista, elaboração teórica pertencente à moderna hermenêutica jurídica, fruto intelectual do aperfeiçoamento histórico dessa ciência da interpretação. Fruto, entretanto, que, apesar de receber grande prestígio nos círculos da produção doutrinária brasileiros, ainda é pouco aproveitado nas práticas dos poderes estatais, tendo presença escassa nos embates que se realizam em nossos tribunais e demais arenas da instância jurídica. Sua importância se dá, entre outras razões, pelo fato de seus métodos favorecerem interpretações progressistas e humanistas da legislação, ações essas que interessam àqueles que não se contentam com os métodos tradicionais, formalistas e distantes da realidade.

Podemos definir o pós-positivismo, com suporte em Barroso e Barcelos, como "um ideário difuso, no qual se incluem a definição das relações entre valores, princípios e regras, aspectos da chamada nova hermenêutica, e a teoria dos direitos fundamentais, edificada sobre o fundamento da dignidade humana" (2010, p. 278-9). Destacaremos, aqui, as duas construções importantíssimas do ideário positivista que importam para este trabalho: a normatividade e aplicabilidade das normas da 


\section{Constituição e a normatividade e aplicabilidade dos princípios.}

O pós-positivismo partiu de uma constatação diagnóstica importante: o positivismo jurídico tradicional, que se baseia na defesa de uma leitura mecânica da legislação e se declara como o caminho para se alcançar um direito adequado

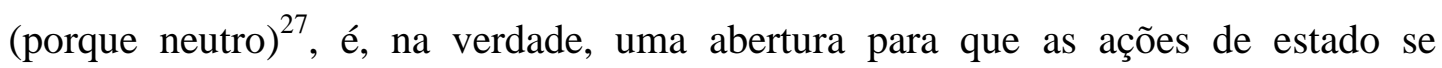
desvinculem de qualquer valoração ética e humana. Essa constatação decorreu, em especial, da observação, no pós-guerra, da atuação dos agentes jurídicos nos estados totalitários fascistas, que cometiam atrocidades amparados por leituras formais e rígidas da legislação. Como pondera Comparato, o positivismo tradicional cria

uma rígida separação entre direito e moral. Contrariando a tradição multissecular de todas as civilizações, os positivistas consideram que o direito existe sem ligação com a justiça, e os juristas não têm que julgar a ordem jurídica de acordo com os grandes valores éticos, porque não é uma tarefa científica e sim política. Ora, a se levar este raciocínio às últimas consequências, teremos, como conclusão lógica, que o terror permanente, estabelecido por um Estado totalitário, não deve interferir na análise fria e objetiva que um jurista faz do sentido, da vigência, ou do âmbito de aplicação das normas editadas por esse Estado. O que significa fazer do sistema jurídico uma simples técnica de manifestação da vontade dominante, no meio social, quaisquer que sejam as finalidades perseguidas pelos que exercem essa dominação (2006, p. 352-3).

Com isso, tem-se um esvaziamento da legitimidade social do direito.

A visão positivista lógico-formal, sob o pretexto de transformar a ciência jurídica em "ciência objetiva", acarreta a separação entre direito e realidade, colocando, falsamente, o agente do direito como um ser à parte da sociedade, fechado aos textos dos códigos, que devem ser interpretados de maneira literal. E isso é acompanhado pela ilusão da despolitização do direito e dos juristas, que passam a não ter mais a incumbência de refletir sobre a legitimidade, a finalidade ou a correção de normas, devendo apenas aplicá-las sem pensar de onde elas vêm ou pra onde elas levam.

Disso já podemos vislumbrar por que o positivismo tem reflexos negativos para a efetividade das normas jurídicas: nele, é vedado ao operador do Direito qualquer esforço criador ao interpretar a lei; seguindo essa diretriz, o operador fica

\footnotetext{
${ }^{27}$ Referimos-nos à formulação clássica do positivismo jurídico, que tem Hans Kelsen como expoente. Podemos sintetizá-la em duas ideias básicas: identificação completa do Direito com a lei escrita posta pelo Estado; e defesa de uma interpretação dessa lei que seja puramente lógica e formal, sem invenção criativa. É a visão ainda predominante nos discursos que permeiam a prática jurídica.
} 
impossibilitado de aplicar qualquer norma que não seja concreta e singela o suficiente para ser aplicada de maneira automática, sem um exercício de pensamento. O problema é que em qualquer ordenamento jurídico sempre há normas assim, ou seja, normas abertas, abstratas, complexas, que não podem ser aplicadas de modo automático: são os princípios, ou normas-princípio. Sob o ideário positivista clássico, entretanto, elas não podem ser aplicadas de fato, apesar de serem normas jurídicas. $\mathrm{O}$ problema se torna mais grave quando percebemos que tem essa característica uma grande parte das normas da Constituição, que é exatamente o corpo normativo que deveria se constituir na lei suprema da ordem jurídica, a mais respeitada de todas as leis. Normas como a do artigo $4^{\circ}, \mathrm{IV}$, da Constituição brasileira, que estabelece que $a$ República do Brasil terá como princípio nas suas relações internacionais a independência nacional, ou a do artigo 170, caput, que determina que a ordem econômica brasileira tem por fim assegurar a todos existência digna. Elas não emitem mandamentos concretos e simples a ninguém; por isso, num mundo onde impera a concepção positivista formal do direito, sua validade real é nula, na prática. No fim, vemos que esse método hermenêutico nos leva a uma grande contradição.

De fato, por ter essas características, a concepção positivista tradicional favorece que as injustiças do modelo econômico capitalista sejam acobertadas pelo direito. Como denuncia Comparato, "não foi por mera coincidência que o avanço internacional do capitalismo deu-se, historicamente, pari passu à difusão do pensamento positivista no campo do direito" (2006, p. 361).

Assim, a partir da constatação desses problemas fundamentais do positivismo, e visando superá-lo como noção - ainda dominante - sobre o que é o direito, surgiu o pós-positivismo jurídico, com a pretensão de construir uma ciência jurídica socialmente mais efetiva e mais humana.

Conforme já adiantamos, há duas elaborações desse ideário que nos importam neste momento: a afirmação da força normativa da Constituição; e o reconhecimento da efetividade dos princípios como normas jurídicas.

A afirmação da força normativa da Constituição, como esclarece Dalmo de Abreu Dallari, é centrada na contraposição à noção, dominante no mundo ocidental na primeira metade do século XX, de que a Constituição seria um mero manifesto político indicador de diretrizes, sem qualquer normatividade (2001, p. 202). 
A afirmação ganhou corpo na voz do alemão Konrad Hesse, que, no célebre discurso intitulado "Força Normativa da Constituição", proferido em 1959 em sua aula inaugural na Universidade de Freiburg, defendeu a normatividade do Direito Constitucional, opondo-se a afirmações do também alemão Ferdinand Lassalle, no sentido de que a "Constituição jurídica" não possuía validade alguma se contraposta à "Constituição real”, formada pelos "fatores reais de poder". De acordo com Hesse, a Constituição jurídica, cuja eficácia depende das condições históricas de sua realização, deve converter-se em força ativa, impondo tarefas ao Estado, que devem ser cumpridas com a participação de todos (HESSE, 1991).

Atualmente, um dos grandes representantes dessa ideia-força é o constitucionalista português Joaquim Canotilho, jurista que se preocupa com a questão da efetividade da Constituição desde seus estudos defensores da “Constituição Dirigente". Canotilho afirma que "no seu conjunto, regras e princípios constitucionais valem como 'lei': o direito constitucional é direito positivo. Nesse sentido se fala na 'constituição como norma' (Garcia de Enterria) e na 'força normativa da constituição' (K. Hesse)" (2003, p. 1176). Nessa linha, Canotilho sustenta que são princípios hermenêuticos constitucionais, ou seja, princípios que sempre devem orientar interpretações que envolvam normas constitucionais, os princípios da máxima efetividade ("a uma norma constitucional deve ser atribuído o sentido que maior eficácia lhe dê") e o da força normativa da Constituição ("na solução dos problemas jurídico-constitucionais deve dar-se prevalência aos pontos de vista que, tendo em conta os pressupostos da constituição (normativa), contribuem para uma eficácia óptima da lei fundamental”) (2003, p. 1224-6).

Em terras brasileiras, a questão da normatividade da Constituição foi encampada pioneiramente (ao menos de forma sistemática) pelo constitucionalista José Afonso da Silva (BARROSO, 2004, p. 249), em seu estudo “Aplicabilidade das normas constitucionais", no qual defendeu, apoiando-se em lições de Ruy Barbosa, que "não há norma constitucional de valor meramente moral ou de conselho, avisos ou lições" (SILVA, 1982, p. 70), de modo que se deve atribuir força imperativa a todas as normas constitucionais. Silva elaborou, então, sua conhecida classificação das normas constitucionais em normas de eficácia plena e aplicabilidade imediata, normas de eficácia contida e aplicabilidade imediata, mas passíveis de restrição, e normas constitucionais de eficácia limitada (que compreendem as normas 
definidoras de princípio institutivo e as definidoras de princípio programático), em geral dependentes de integração infraconstitucional para operarem a plenitude de seus efeitos (SILVA, 1986, p. 72-3). Vale dizer que, nesse modelo, mesmo as normas de eficácia limitada têm efeitos; só não os têm em plenitude, ao menos enquanto não houver integração infraconstitucional. Desse modo, desde logo a norma limitada terá, ao menos, eficácia interpretativa (condicionando e informando o intérprete) e eficácia negativa (proibindo a edição de normas contrárias).

Atualmente, a corrente iniciada por Silva tem como grande expoente o jurista carioca Luís Roberto Barroso, que retomou o estudo de Silva, mudando, no entanto, o foco para a efetividade das normas constitucionais (2004, p. 250).

Barroso iniciou seu estudo destacando a existência de um quarto plano de análise do ato jurídico, o plano da efetividade - para além dos três planos tradicionalmente reconhecidos: existência, validade e eficácia - que representaria “a materialização, no mundo dos fatos, dos preceitos legais e simboliza a aproximação [...] entre o dever-ser normativo e o ser da realidade social". Seguindo essa linha, observou que há casos em que preceitos normativos são descumpridos de forma expressiva ou mesmo generalizada; seriam os casos, por exemplo, em que "uma norma se confronta com um sentimento social arraigado", ou "contrarie interesses particularmente poderosos" (2004, p. 246-8). Em seguida, Barroso afirma:

a Constituição, uma vez posta em vigência, é um documento jurídico. $\mathrm{E}$ as normas jurídicas, tenham caráter imediato ou prospectivo, não são opiniões, meras aspirações ou plataforma política. As regras de direito, consigna Recaséns Siches, "son instrumentos práticos, elaborados y construidos por los hombres, para que, mediante su manejo, produzcan em la realidad social unos ciertos efectos, precisamente el cumplimiento de los propósitos concebidos" (2004, p. 249).

Em conclusão, "toda norma constitucional é dotada de eficácia jurídica e deve ser interpretada e aplicada em busca de sua máxima efetividade” (2004, p. 272).

Acerca da afirmação sobre a força normativa da Constituição, é relevante mencionar, por último, a emergente corrente hermenêutica autodenominada neoconstitucionalismo, cuja contribuição reside em ressaltar que a normatividade constitucional alcança, também, as relações privadas e o direito privado. Segundo Garcia, o neoconstitucionalismo teria o objetivo de assentar "um novo centro gravitacional no sistema jurídico; a Constituição não mais imanta apenas nos ramos 
de direito público, mas também invade as relações privadas, relativizando sua autonomia forjada pelo modelo formal-burguês" (2010, p. 296-7).

De mão dadas com a postura que afirma a força normativa da Constituição, está a postura que reconhece a efetividade de princípios como normas jurídicas, outra ideia central do pós-positivismo.

A indissociabilidade entre as duas posturas existe por um motivo simples: grande parte das normas da Constituição, e muitas delas de grande importância jurídico-social, são princípios; portanto, teria pouco efeito prático reconhecer a força normativa da Constituição sem encarar os princípios constitucionais como normas jurídicas cogentes.

Sobre esse tema, dois nomes se destacam: em primeiro lugar, o jusfilósofo estadunidense Ronald Dworkin, que, em sua obra célebre, Taking Rights Seriously, publicada pela primeira vez em 1977, defendeu, em crítica ao positivista formal Hart, uma classificação exaustiva das normas jurídicas em duas categorias. As regras, que seriam as normas com mandamentos elementares e determinados, cujo cumprimento se daria em termos absolutos, de "tudo ou nada" (por exemplo, a norma do inciso III do artigo $7^{\circ}$ da Constituição brasileira, que prevê que o fundo de garantia por tempo de serviço é direito dos trabalhadores). E os princípios, normas cujos mandamentos não se dariam nesses termos absolutos (por exemplo, a norma do inciso XX do artigo $7^{\circ}$, que prevê ser direito dos trabalhadores a "proteção do mercado de trabalho da mulher, mediante incentivos específicos, nos termos da lei”) (1978, p. 24). Assim, se falamos, hoje, em princípios da ordem jurídica, em oposição a regras, isso deve à elaboração teórica de Dworkin.

O outro nome a ser ressaltado é o do alemão Robert Alexy que, em sua influente obra Teoria dos Direitos Fundamentais, de 1985, desenvolveu a categorização dualista de Dworkin. Alexy procurou aperfeiçoar o binômio, defendendo que

princípios são normas que ordenam que algo seja realizado na maior medida possível dentro das possibilidades jurídicas e fáticas existentes. Princípios são, por conseguinte, mandamentos de otimização, que são caracterizados por poderem ser satisfeitos em graus variados e pelo fato de que a medida de sua satisfação não depende somente das possibilidades fáticas, mas também das possibilidades jurídicas. O âmbito das possibilidades jurídicas é 
determinado pelos princípios e regras colidentes.

Já as regras são normas que são sempre ou satisfeitas ou não satisfeitas. Se uma regra vale, então, deve se fazer exatamente aquilo que ela exige; nem mais, nem menos. Regras contêm, portanto, determinações no âmbito daquilo que é fática e juridicamente possível (2008, p. 90).

Enquanto um conflito entre regras antagônicas se solucionaria pela invalidação absoluta de uma das duas regras, uma colisão entre princípios seria solucionada de forma a reconhecer-se a precedência de um dos princípios sobre o outro naquelas condições em que a colisão acontece (uma precedência relativa, portanto). Para a determinação dessa precedência, o intérprete deveria socorrer-se da máxima da proporcionalidade em sentido estrito (2008, p. 91-103).

Postas essas premissas, a consequência trazida pela teoria é a promoção da centralidade dos princípios no sistema normativo. Entendidos como mandamentos de otimização, os princípios passam a emanar sua força normativa para toda a ordem jurídica, pois são potencialmente aplicáveis a qualquer caso concreto. De mero recurso de preenchimento de lacunas, eles passam a ser espinha dorsal do sistema (FELICIANO, 2005, p. 89-90). Nesse modelo, a contraposição de uma regra específica a um princípio só não causa antinomia se houver outro princípio que a justifique (e que prevaleça na colisão com o primeiro). Assim, passa a ser possível, por exemplo, o reconhecimento da inconstitucionalidade de uma regra infraconstitucional, sob determinadas condições, baseada apenas em sua contradição a um princípio constitucional, como o princípio do valor social do trabalho (artigo $1^{\circ}$, IV, da Constituição brasileira), se não houver outro princípio constitucional contraposto que a suporte.

Os princípios, então, passam a ter função relevante, porque conformam toda a ordem jurídica. Esse caráter globalizante dos princípios é visto quando juristas da atualidade, inspirados na visão pós-positivista, identificam quais seriam os papéis dos princípios no sistema jurídico. Barroso, por exemplo, defende que os princípios cumpririam três papéis na ordem jurídica: a) condensar valores (espelham a ideologia da sociedade, seus postulados básicos, seus fins); b) dar unidade ao sistema (integrando suas diferentes partes e atenuando tensões normativas); $c$ ) condicionar a atividade do intérprete (cuja atuação deve se pautar pela identificação do princípio maior que rege o tema apreciado, descendo do mais genérico ao mais 
específico, até chegar à formulação da regra concreta que vai reger a espécie) (2004, p. 327).

De fato, o reconhecimento da efetividade dos princípios se harmoniza com a própria concepção atual de direito como sistema. É o que esclarece Guilherme Feliciano, ao ponderar que o convencimento tradicional de que a função dos princípios jurídicos é a aplicação subsidiária em impasses interpretativos,

se um dia foi adequado, não resiste à concepção sistêmica e autopoiética do Direito contemporâneo. [...]

[...] uma percepção genuinamente sistêmica do ordenamento jurídico conduz os princípios à condição de espinha dorsal do Direito positivo, rechaçando qualquer pretensão de subsidiariedade que ainda dimane da ciência jurídica oitocentista. Os princípios gerais não são meros recursos periféricos de colmatação de lacunas; antes, são eles - e não as regras - a "parte vital" do sistema jurídico (2005, p. 89-91).

Uma consequência importante do reconhecimento da efetividade dos princípios é a aproximação das interpretações jurídicas com a ética e com a realidade social. Abrindo-se aos princípios, o intérprete abre-se à sociedade. Como pontuam Barcellos e Barroso, "a valorização dos princípios, sua incorporação, explícita ou implícita, pelos textos constitucionais e o reconhecimento pela ordem jurídica de sua normatividade fazem parte desse ambiente de reaproximação entre direito e ética" (2010, p. 279).

O reconhecimento da normatividade e da centralidade dos princípios, portanto, é relevantíssima inovação à ciência hermenêutica jurídica trazida pelo ideário pós-positivista, conferindo aos princípios uma função humanizadora da leitura da legislação.

É importante ressaltar que a ordem jurídica brasileira atual é plenamente ajustada ao ideário pós-positivista. É o que ressalta Barroso, ao afirmar que, após a vivência pelo Brasil de uma história constitucional triste, desde 1988

a efetividade da Constituição, rito de passagem para o início da maturidade institucional brasileira, tornou-se uma ideia vitoriosa e incontestada. As normas constitucionais conquistaram status pleno de normas jurídicas, dotadas de imperatividade, aptas a tutelar direta e imediatamente todas as situações que contemplam. Mais do que isso, a Constituição passa a ser a lente através da qual se lêem e se interpretam todas as normas infraconstitucionais (2004, p. 273). 
E completa:

Gradativamente, diversas formulações antes dispersas ganham
unidade e consistência, ao mesmo tempo em que se desenvolve o
esforço teórico que procura transformar o avanço filosófico em
instrumental técnico-jurídico aplicável aos problemas concretos. O
discurso acerca dos princípios, da supremacia dos direitos
fundamentais e do reencontro com a ética - ao qual, no Brasil, se
deve agregar o da transformação social e o da emancipação - deve
ter repercussão sobre o ofício dos juízes, advogados e promotores,
sobre a atuação do poder público em geral e sobre a vida das
pessoas. Trata-se de transpor a fronteira da reflexão filosófica,
ingressar na dogmática jurídica e na prática jurisprudencial e, indo
mais além, produzir efeitos positivos sobre a realidade (2004, p.
279).

Desse modo, o que se conclui é que, à luz dos postulados hermenêuticos contemporâneos, identificados pelo signo do pós-positivismo, é adequado e esperado o reconhecimento de que a Constituição e os princípios jurídicos são dotados de força normativa e imperatividade jurídica. Voltando-nos ao Brasil, temos que os princípios constitucionais da Constituição de 88 devem iluminar toda a ordem infraconstitucional nacional. E, no âmbito dos conflitos jurídicos emergentes nas recuperações operárias, podemos concluir que os três princípios constitucionais centrais para esse fenômeno (da função social da propriedade, do direito ao trabalho e do valor social do trabalho e da livre iniciativa) têm efeitos imediatos sobre casos concretos de recuperação.

3.2.3 Efeitos das normas-princípio: uma ordem constitucional das continuações operárias

Tendo desenvolvido essas explicações acerca da moderna teorização póspositivista, temos base para ir um pouco além na definição dos efeitos jurídicos dos três princípios constitucionais basilares das recuperações operárias.

Acima afirmamos, sobre o conteúdo normativo desses três princípios, que:

1. O princípio do artigo $1^{\circ}, \mathrm{IV}$, da Constituição (valor social do trabalho e 
da livre iniciativa) "garante a liberdade capitalista de empreender e explorar na arena econômica e, ao mesmo tempo, promete proteção estatal para a classe trabalhadora".

2. O princípio do artigo $6^{\circ}$, da Constituição (direito ao trabalho) implica o "reconhecimento de que a população precisa de trabalho para viver e gozar de direitos, e, com ele, a promessa de que o estado deverá agir junto à economia no sentido de garantir trabalho digno para todos".

3. O princípio do artigo 170, III, da Constituição (função social da propriedade) impõe que "sempre que um empresário em crise houver praticado atos ilegais ou antissociais (que prejudiquem interesses coletivos em favorecimento de interesses egoístas), a proteção jurídica de sua propriedade ficará sujeita a desaparecer, o que efetivamente se concretizará se os trabalhadores desafiarem seu controle efetivo da atividade produtiva e sua legitimidade manifestando a intenção de continuar a empresa coletivamente. Em outras palavras, a prática de atos empresariais ilegais ou antissociais abre, para o coletivo operário, o caminho para assunção juridicamente legítima da atividade”.

Sem dúvida, os efeitos presentes nessas conclusões já têm relevância para os coletivos operários nos enfrentamentos jurídicos das recuperações.

No entanto, podemos aprofundar mais e detalhar melhor essa construção, com benefícios potenciais ainda melhores para o movimento, se utilizarmos, como suporte, as férteis elaborações teóricas pós-positivistas acerca das funções dos princípios no sistema jurídico.

Essas elaborações decorrem da pergunta que surge imediatamente após as afirmações de efetividade dos princípios e da Constituição: se, então, os princípios constitucionais têm efeitos jurídicos imediatos, que efeitos são esses? Ou seja, como os princípios da Constituição podem influenciar a prática jurídica?

Juristas respeitados já se dedicaram à tarefa de responder a essas perguntas, e, para este trabalho, investigamos as conclusões de três deles: Joaquim Canotilho, 
Robert Alexy e Luís Roberto Barroso ${ }^{28}$.

A partir da análise empreendida, podemos afirmar que existem, pelo menos, quatro funções jurídico-positivas para os princípios constitucionais.

A primeira das funções dos princípios identificada pela doutrina é a imposição de legislar: os princípios proferem um mandamento positivo ao legislador para que edite leis que materializem suas previsões, sob pena de incorrer em inconstitucionalidade por omissão.

Discorrendo sobre os direitos fundamentais sociais, o constitucionalista Canotilho afirma que "as normas de legislar acopladas à consagração de direitos sociais são autênticas imposições legiferantes, cujo não cumprimento poderá justificar, como já se referiu, a inconstitucionalidade por omissão" (2003, p. 482). E, para o constitucionalista, vale o mesmo para as normas programáticas: “a positividade jurídico-constitucional das normas programáticas significa fundamentalmente: (1) vinculação do legislador, de forma permanente, à sua realização (imposição constitucional) [...]" (2003, p. 1177).

Outra função dos princípios é a imposição de desenvolver políticas públicas: eles criam um dever ao poder público de realizar políticas públicas que materializem suas previsões.

Canotilho também reconhece esta função. Dissertando sobre os direitos econômico-sociais, o jurista sustenta que uma de suas funções é a de prestação social, da qual decorre que "as normas consagradoras de direitos sociais, económicos e culturais da Constituição Portuguesa de 1976 individualizam e impõem políticas públicas socialmente activas" (2003, p. 409), e que

a efectivação dos direitos económicos, sociais e culturais não se reduz a um simples "apelo" ao legislador. Existe uma verdadeira imposição constitucional legitimadora, entre outras coisas, de transformações económicas e sociais na medida em que estas forem necessárias para a efectivação desses direitos. (...) os direitos fundamentais sociais consagrados em normas da

\footnotetext{
${ }^{28}$ Importa esclarecer que estamos utilizamos o termo princípios, mas, em nossa análise da literatura, consideramos, também, as conclusões sobre funções identificadas a outras tipologias utilizadas pelo autor Canotilho que correspondem à categoria norma-princípio, ou se assemelham a ela em sua função normativa. Referimo-nos às seguintes tipologias: normas de direitos fundamentais econômicos, sociais e culturais (os chamados direitos humanos de segunda dimensão, como o direito ao trabalho, à moradia e à saúde); e normas programáticas (normas que colocam objetivos ou tarefas que devem ser observados pelo poder público, também chamadas de "normas-fim" ou "normas-tarefa").
} 
Constituição dispõem de vinculatividade normativo-constitucional (não são meros "programas" ou "linhas de direcção política"); [...] as tarefas constitucionalmente impostas ao Estado para a concretização destes direitos devem traduzir-se na edição de medidas concretas e determinadas e não em promessas vagas e abstratas (2003, p. 478 e 482).

O constitucionalista também defende a função impositiva de políticas públicas para as normas programáticas, como se infere do seguinte trecho:

a positividade jurídico-constitucional das normas programáticas significa fundamentalmente: (...) (2) vinculação positiva de todos os órgãos concretizadores, devendo estes tomá-las em consideração como directivas materiais permanentes, em qualquer dos momentos da actividade concretizadora (legislação, execução, jurisdição) (2003, 1177).

Vinculada a essa função existe, atualmente, uma discussão sobre a possibilidade de os princípios gerarem diretamente direitos subjetivos para os cidadãos que se vejam privados dos benefícios neles veiculados (como o direito à moradia, garantido no caput do artigo $7^{\circ}$ da Constituição brasileira). Acreditamos, entretanto, que essa argumentação é carente de sustentação real. Há críticas coerentes a ela tanto de perspectiva liberal (o reconhecimento de direitos subjetivos causaria, no limite, uma excessiva intervenção estatal na economia) quanto de perspectiva marxista (é ilusório acreditar que o estado tem poder para intervir no mundo de forma tão robusta a ponto de garantir efetivamente direitos sociais a todos; as declarações legais de direitos sociais são mera ideologia, com função de acalmar as reivindicações por dignidade da classe trabalhadora e que, na prática, são impossíveis de serem realizadas no capitalismo ${ }^{29}$ ).

Prosseguindo, os princípios também têm a função proibitiva, ou negativa: além de terem a eficácia de impor uma posição ativa do poder público, têm a eficácia de proibi-lo de praticar atos contrários ao seu conteúdo.

Recorrendo novamente a Canotilho, vemos que o jurista reconhece essa função ao falar das normas programáticas:

a positividade jurídico-constitucional das normas programáticas significa fundamentalmente: [...] (3) vinculação, na qualidade de limites materiais negativos, dos poderes públicos, justificando a eventual censura, sob a forma de inconstitucionalidade, em relação a certos atos que as contrariam (2003, p. 1177).

\footnotetext{
${ }^{29}$ Sobre essa visão, que é, também, nossa, remetemos o leitor ao segundo capítulo deste trabalho.
} 
As normas constitucionais programáticas têm ainda efeito "derrogatório" ou "invalidante" dos actos normativos incompatíveis com as mesmas, devendo, porém, precisar-se (e isso nem sempre é fácil) em que medida as normas programáticas servem de limite negativo às leis consagradoras de disciplina contrária. Para além destes "efeitos directos", deve reconhecer-se que as normas-tarefa e normas-fim pressupõem, em larga medida, a clarificação conformadora efectuada pelas autoridades com poderes político-normativos (2003, p. 1180).

Uma última função dos princípios, que talvez seja a mais importante de todas, é a interpretativa: os princípios servem como ferramentas informadoras e integradoras na atividade interpretativa, de modo que seus mandamentos sempre devem ser considerados pelo intérprete jurídico.

O jurista português também destaca essa função, tanto quando trata das normas de direitos econômico-sociais: "as normas constitucionais consagradoras dos direitos sociais, económicos e culturais implicam, além disso, uma interpretação das normas legais de modo conforme com 'a constituição social económica e cultural"' (2003, p. 478), quanto das normas programáticas:

Além de constituírem princípios e regras definidoras de directrizes para o legislador e a administração, as "normas programáticas" vinculam também os tribunais, pois os juízes "têm acesso à constituição", com o consequente dever de aplicar as normas em referência (por mais geral e indeterminado que seja o seu conteúdo) (2003, p. 1180).

A maior contribuição teórica para a função interpretativa dos princípios, entretanto, é, certamente, a do alemão Robert Alexy. Como já expusemos no tópico anterior, ao definir os princípios como mandamentos de otimização e estabelecer que a colisão de princípios seria resolvida pela máxima da proporcionalidade em sentido estrito, Alexy contribuiu para a promoção da centralidade dos princípios. E essa centralidade se dá exatamente por processos hermenêuticos. Lançando mão dos instrumentos interpretativos propostos pelo constitucionalista, pode-se chegar, por uma via de argumentação jurídica racional, a um resultado poderoso, inimaginável em um contexto positivista clássico: o reconhecimento da invalidade de uma regra do ordenamento jurídico apenas pela contraposição a princípios regentes do sistema ${ }^{30}$.

A função interpretativa dos princípios também foi trabalhada pelo brasileiro

\footnotetext{
${ }^{30}$ Retornaremos, no tópico à frente sobre a legalidade da greve de ocupação, à teoria de Alexy e à técnica do sopesamento. A utilizaremos para analisar a colisão entre os princípios da função social da propriedade e da posse e o direito de propriedade que emerge nos casos de greve de ocupação.
} 
Luís Roberto Barroso. O constitucionalista aponta, como já mencionamos no tópico anterior, três papéis que seriam reservados aos princípios no sistema jurídico. Dois desses papéis são relacionados a sua função interpretativa, que são: dar unidade ao sistema, "integrando suas diferentes partes e atenuando tensões normativas"; e condicionar a atividade do intérprete, "cuja atuação deve pautar-se pela identificação do princípio maior que rege o tema apreciado, descendo do mais genérico ao mais específico, até chegar à formulação da regra concreta que vai reger a espécie" (2004, p. 327).

A partir desse aporte teórico, uma decorrência importante da função interpretativa dos princípios que deve ser ressaltada é a possibilidade de reconhecimento da inconstitucionalidade de normas ou atos do poder público contrários a seus mandamentos, o que é cabível sempre que o princípio violado tem status constitucional. Essa possibilidade é salientada por Canotilho para violações a normas de direitos fundamentais de segunda dimensão:

as normas constitucionais consagradoras de direitos económicos, sociais e culturais implicam a inconstitucionalidade das normas legais que não desenvolvem a realização do direito fundamental ou a realizam diminuindo a efectivação legal anteriormente atingida. [...] as normas garantidoras de direitos sociais devem servir de parâmetro de controlo judicial quando esteja em causa a apreciação da constitucionalidade de medidas legais ou regulamentares restritivas destes direitos [...] (2003, p. 478 e 482).

E, também, para violações a normas programáticas - em continuidade à passagem citada acima:

\begin{abstract}
Além de constituirem princípios e regras definidoras de directrizes para o legislador e a administração, as "normas programáticas" vinculam também os tribunais, pois os juízes "têm acesso à constituição", com o consequente dever de aplicar as normas em referência (por mais geral e indeterminado que seja o seu conteúdo) e de suscitar o incidente de inconstitucionalidade, nos feitos submetidos a julgamento (cfr. CRP, art. 204. ${ }^{\circ}$ ), dos actos normativos contrários às mesmas normas (2003, p. 1180).
\end{abstract}

Vale dizer que a função interpretativa dos princípios se dirige a todo tipo de intérprete da lei, ou seja, inclui o juiz, a administração pública, o legislador (que deve considerar o sistema jurídico-constitucional existente na elaboração de novas normas) e mesmo qualquer cidadão que se lance, por qualquer motivo juridicamente relevante, à interpretação da lei. Por isso, inclusive, essa função é inseparável das demais: para legislar, desenvolver políticas públicas e proibir atos com base em 
princípios, é necessário, antes, interpretar o sistema normativo considerando as determinações dos princípios que o estruturam.

Diante do exposto, concluímos que, de acordo com os postulados da dogmática jurídica contemporânea, existem pelo menos quatro efeitos jurídicopositivos que devem decorrer de um princípio constitucional:

1. A imposição ao legislador de criar leis favoráveis à materialização do princípio;

2. A imposição à administração pública de desenvolver políticas públicas concretizadoras do princípio;

3. A proibição de realizar atos contrários ao princípio, proibição vinculante para os poderes estatais;

4. A influência obrigatória sobre toda interpretação feita das normas vigentes, da qual decorre a possibilidade do reconhecimento da inconstitucionalidade de um ato ou norma contrário ao princípio.

O transporte dessas conclusões para o campo das recuperações operárias é de grande riqueza teórica. Trabalhando sobre os três princípios constitucionais basilares desse fenômeno - os princípios do valor social do trabalho e da livre iniciativa, do direito ao trabalho, e da função social da propriedade - podemos compreender o real tratamento dado pela ordem constitucional a esse fenômeno.

Desenvolvendo essa investigação, poderemos afirmar que esses três princípios constituem a estrutura de um microssistema normativo da Constituição, uma ordem constitucional das recuperações operárias.

Ordem constitucional que profere mandamentos vinculantes a todos os atores estatais da arena jurídica - juízes, parlamentares, governantes etc. determinando que, no tratamento das questões emergentes das recuperações operárias, esses atores devem:

1. Criar leis dedicadas às recuperações operárias que: garantam a liberdade de iniciativa econômica do coletivo operário (artigo $1^{\circ}, \mathrm{IV}, \mathrm{CF}$ ), protejam o trabalho e a fonte de renda dos operários auto-organizados (artigo $1^{\circ}, \mathrm{IV}$, e $6^{\circ}, \mathrm{CF}$ ), privilegiem os trabalhadores como controladores 
das empresas em crise que cumprem melhor a função social da empresa e dos bens de produção (artigo 170, III, CF) e prevejam sanções para os empresários capitalistas que violam a função social dos bens de produção (artigo 170, III, CF).

2. Desenvolver políticas públicas dedicadas às recuperações operárias que: favoreçam as iniciativas econômicas do coletivo operário (com programas de acesso a crédito, por exemplo) (artigo $1^{\circ}, \mathrm{IV}, \mathrm{CF}$ ), e forneçam suporte às recuperações por serem fonte de trabalho e renda para os operários auto-organizados (artigo $1^{\circ}$, IV, e $6^{\circ}, \mathrm{CF}$ ) e por cumprirem melhor a função social da empresa e dos bens de produção (artigo 170, III, CF).

3. Não realizar atos contrários às recuperações sem justificativas constitucionais, se elas se constituírem em materialização dos três princípios (como, em geral, se constituem). Ou seja, se elas se constituírem como: a) expressão da liberdade de iniciativa econômica e, em especial, de iniciativa econômica não-capitalista (artigo $1^{\circ}, \mathrm{IV}$, $\mathrm{CF}$ ); b) meio de proteção e garantia de trabalho e renda (artigo $1^{\circ}, \mathrm{IV}$, e $\left.6^{\circ}, \mathrm{CF}\right)$; c) e, também, meio de promoção de um melhor cumprimento da função social da empresa e dos bens de produção (artigo 170, III, CF). Além disso, os agentes jurídicos também estão proibidos de desfavorecer os recuperadores operários em favor dos empresários capitalistas que tenham praticado atos ilegais ou antissociais e, com isso, violado a função social da empresa e da propriedade dos bens de produção (artigo 170, III, CF).

4. E, por último, interpretar a legislação, no tratamento dos casos de recuperação, considerando a influência vinculante desses três princípios. Ou seja, os agentes do direito, na tarefa de interpretar as leis incidentes sobre os casos de recuperação (por exemplo, a lei de greve, lei de falências, lei das cooperativas, lei de execução fiscal, lei processual civil e do trabalho etc.), ao se depararem com dúvidas quanto ao sentido de uma norma, lacunas normativas ou contradição entre normas, devem optar pela interpretação que aja no sentido de: garantir a liberdade de 
iniciativa econômica do coletivo operário (artigo $1^{\circ}$, IV, CF); e favorecer as recuperações enquanto fontes de trabalho e renda para os operários auto-organizados (artigo $1^{\circ}$, IV, e $6^{\circ}, C F$ ) e meio de melhor cumprimento da função social da empresa e dos bens de produção (artigo 170, III, CF); e sancionar os atos empresariais ilegais ou antissociais que violem a função social da empresa e dos bens de produção (artigo 170, III, CF). Além disso, ao interpretar a legislação, esses atores estatais deverão reconhecer a inconstitucionalidade e a consequente invalidade jurídica de normas ou atos oficiais contrários a esses princípios, caso nenhum outro princípio constitucional suporte a legitimidade dessas normas ou atos oficiais.

É essa a extensão das determinações constitucionais sobre os processos de continuação operária de empresas. Mirando-as, podemos perceber o quanto nosso texto constitucional é favorável a esses processos. E, portanto, o quanto os recuperadores e partidários do movimento podem se utilizar abundantemente da Constituição de 88 para defender, nos espaços públicos, seu intento.

Importa retomar algo que já explicitamos no final do segundo capítulo, e de que nunca podemos esquecer. Temos em mãos essa elaboração teórica favorável aos trabalhadores, coerente e robusta porque desenvolvida com base em respeitados cientistas jurídicos, desenvolvida com base nesses três princípios constitucionais basilares. No entanto, esses mesmos três princípios, nas mãos da burguesia, podem se transformar em um discurso vazio e que apenas legitime a sua dominação. Ou, até mesmo, em suporte para a precarização e redução de direitos (o direito ao trabalho, por exemplo, é comumente usado nas teses de defesa da "flexibilização"). Queremos dizer que conclusões teóricas jurídicas, sozinhas, não representam nada, são apenas papel. O que realmente pode transformar o mundo é a ação da classe trabalhadora auto-organizada em igualdade, na luta pelo controle da produção, como a ação dos operários recuperadores de empresas, por exemplo. Mas essa ação necessita de suportes teóricos para se desenvolver, não só da área jurídica, mas de todas as demais; pois prática e teoria precisam se sustentar numa dinâmica dialética. Como bem coloca Tarso de Melo, 
realidade econômica e social a ser construída por meio de sua própria aplicação. É nesse sentido que ela, nos pontos em que é mais progressista, pode servir de 'cavalo de batalha' para que a sociedade busque a melhoria de suas condições de vida, organizando-se politicamente de modo a constituir novas relações de poder capazes de sustentar faticamente a concretização dos programas constitucionais (MELO, 2009, p. 47).

É apenas nesse contexto que elaborações teóricas como a que construímos neste capítulo deixarão de ser apenas discurso para se transformarem em instrumentos reais de materialização de outro mundo.

Afirmamos que os três princípios basilares impõem diversas atitudes aos agentes do estado, mas a verdade é que esses agentes nunca agirão nesse sentido por sua própria iniciativa. $\mathrm{O}$ estado é burguês e por isso age, em geral, em favor da classe empresarial capitalista. Classe que não vê as recuperações operárias com bons olhos. Por isso, os agentes jurídicos só cumprirão as imposições desses três princípios em favor dos trabalhadores se forem pressionados politicamente para tanto. Cabe aos trabalhadores auto-organizados mobilizarem-se e transformarem essas imposições do texto constitucional em realidade material.

\subsubsection{Uma questão para os céticos: ERTs geram trabalho e renda?}

Há uma questão, não propriamente jurídica, mas fundamental para as conclusões as quais chegamos e que, certamente, será colocada pelos céticos. É a seguinte: defender as recuperações operárias significa, realmente, defender o direito ao trabalho e a função social da propriedade? Ou seja, as empresas recuperadas por trabalhadores geram trabalho e renda? Qual é a garantia de que os operários terão êxito em movimentar o negócio?

A questão coloca em cheque a possibilidade de êxito econômico de uma empresa sob a responsabilidade coletiva de trabalhadores. E é, de fato e a princípio, questão relevante. De nada adiantaria lapidar todo um instrumental jurídico de assistência à continuação operária se, no mundo real, esse tipo de empreendimento 
não rendesse frutos.

A questão, portanto, é pertinente. Todavia, um olhar investigativo para a realidade atual desse fenômeno é suficiente para superá-la.

Desde que o fenômeno da recuperação de fábricas tornou-se perene, no último quarto do século passado ${ }^{31}$, parte considerável das recuperações iniciadas em todo o mundo se estabilizaram e estão em atividade até hoje, sendo fonte de sustento para seus integrantes.

No Brasil, por exemplo, das 67 ERTs em operação, quatro iniciaram seus processos de recuperação na década de 1980 (HENRIQUES et al., 2013, p. 51), ou seja, há 23 anos ou mais. Por certo, há muitas empresas capitalistas tradicionais inauguradas nesta década que não tiveram a mesma sorte. Outro dado relevante: essas 67 empresas operárias que funcionam hoje representam $46 \%$ do total de ERTs que já existiram no Brasil (HENRIQUES et al., 2013, p. 244-51).Sendo assim, praticamente metade dos processos de continuação operária iniciados no país teve sucesso. Também valeria a pena comparar essa última estatística com a taxa de fechamento de empresas capitalistas.

Outra estatística, desta vez internacional, é trazida pela The Working World, entidade de financiamento dedicada exclusivamente a empreendimentos de gestão operária, que tem sede em três países americanos (Argentina, Nicarágua e EUA). Segundo seu diretor, Brendan Martin, dos 150 empreendimentos financiados e assessorados pela Working World, aproximadamente 90\% é rentável (BUSHEI, 2013).

E não se olvide de que esses empreendimentos operários sempre enfrentaram condições adversas atípicas, se compararmos com os empreendimentos tradicionais. A primeira é o fato de a retomada sempre partir de uma empresa em crise (muito endividada e, na maioria das vezes, com maquinário ultrapassado). A segunda é que, como já demonstramos, a lei e o estado não facilitam o processo de recuperação. Vale lembrar os casos já estudados da Cipla e da Interfibra, ERTs que estão na lista de recuperações operárias encerradas, mas cujo encerramento se deu por força policial, em 2007. E a terceira, e mais importante, é que a maioria dos

\footnotetext{
${ }^{31}$ Sobre esse movimento histórico veja o leitor no capítulo 1, o tópico 1.2.
} 
trabalhadores que decidem recuperar empresas acaba não tendo desenvolvido certas habilidades necessárias para a gestão, como a de se comunicar por escrito com proficiência, pois, via de regra, não tiveram acesso a uma formação educacional eficiente, justamente porque sua escolarização se deu nas escolas estatais, que servem para formar executores de funções elementares e não gestores ${ }^{32}$.

Essa taxa de sucesso - cuja tendência é aumentar, com o desenvolvimento de métodos de gestão específicos - talvez seja explicada pelas razões colocadas por Paul Singer:

Por surpreendente que seja, a grande maioria das tentativas de transformar firmas meio ou inteiramente falidas em empresas solidárias tem tido sucesso. Isso é explicado, em primeiro lugar, pelos sacrifícios feitos pelos cooperados, que se dispõem a trabalhar durante meses por ganhos mínimos, algumas vezes apenas em troca de cestas básicas [...]. Mas também pela enorme dedicação e amor ao trabalho não mais alienado, do que resultam aumentos inesperados de produtividade e grande redução de perdas e desperdícios. E, finalmente, pelo aprendizado por parte dos novos administradores das técnicas e manhas da gestão de comprar e vender, de receber e dar crédito, de inovar produtos e processos e de tecer relações solidárias com outras autogestões (2012, p. 91).

Desse modo, podemos afirmar com segurança que, se os trabalhadores resolverem encarar o desafio de recuperar sua empresa, terão chances razoáveis de obter êxito.

Hoje, quase doze mil trabalhadores brasileiros estão sustentando a si mesmos e suas famílias não com empregos tradicionais, mas, sim, com trabalhos diferentes, de mais responsabilidade, em empreendimentos coletivos de recuperação de empresas.

Portanto, temos razões de sobra para crer na continuação de empresas sob o controle operário como caminho para geração de trabalho e renda. E o estado e a ordem jurídica têm fundamentos em abundância para favorecê-la. Em especial quando quem reivindica essa continuação são os próprios operários, o que indica que eles já estão auto-organizados e já se dispuseram a encarar esse desafio.

\footnotetext{
${ }^{32}$ Não esqueçamos que essa condição é decorrente da ação classista da própria burguesia, que controla o mundo em função do processo produtivo capitalista e deve manter a pirâmide de divisão desigual do trabalho estável.
} 


\subsection{Licitude da greve de ocupação}

No Brasil, toda vez que uma greve de trabalhadores se anuncia, a grande mídia se adianta para falar dos prejuízos que a greve pode gerar. Realiza-se uma forte campanha para construir uma avaliação negativa do movimento e de seus

líderes. [...] é fundamental ater-se à noção da relevância social da greve, que ultrapassa, em muito, os interesses localizados de uma categoria específica de trabalhadores para a defesa de valores imediatos. Neste sentido, importa recordar que foi a organização dos trabalhadores um dos fatores mais determinantes para a formatação das estruturas democráticas hoje existentes. Não é exagero dizer que a luta dos trabalhadores, em âmbito mundial, por meio das greves, foi o que permitiu construir, efetivamente, a democracia [...].

No segundo semestre do ano de 2013, no Estado do Pará, estado com a pior taxa de conclusão do ensino fundamental da Região Norte do Brasil (53,3\% das pessoas em idade de trabalhar do estado não têm o diploma, conforme o Censo 2010 do IBGE), os professores da rede pública estadual estavam mobilizados por reivindicações trabalhistas. Com a bandeira de que uma educação pública de qualidade requer a valorização dos profissionais da educação, os trabalhadores da educação decidiram que era hora de reverter a situação inadmissível em que se encontravam: uma jornada de trabalho irregular (por não cumprir o mínimo de 1/3 de atividades extraclasse), escolas necessitando de reformas, salas de aula superlotadas, autoritarismo institucional e correção salarial abaixo da inflação. Diante da ausência de qualquer abertura do governo para negociação, eles decidiram, após deliberação em assembleia, deflagrar greve. A greve se iniciou no dia 23 de setembro e contou com alta adesão da categoria. Entretanto, a cúpula do governo continuou ignorandoos. Resistindo, sabendo que não teriam espaço na mídia nem meios "oficiais" para serem ouvidos pela população, os trabalhadores começaram a organizar ações mais proeminentes. No dia 17 de outubro, realizaram uma marcha que interditou a rodovia BR 155. Indo além, no dia 24 de outubro, ocuparam a sede da Secretaria de Educação, ato que, durando três dias, lhes rendeu uma grande repercussão nacional. Essa ocupação foi encerrada com uma ação policial violenta. Como o governo 
continuou intransigente, o coletivo prosseguiu com sua luta e, em 05 de novembro, ocupou a Assembleia Legislativa do Estado. A ocupação, que durou 08 dias, gerou grande pressão sobre o governo, que foi intensificada pela ação dos servidores estaduais da segurança pública (policiais civis e militares, bombeiros e fiscais de trânsito), que, no dia 08 de novembro, também se mobilizaram contra o estado e bloquearam ruas em frente à prefeitura de Belém, reivindicando melhores condições de trabalho. Pressionado, o governo estadual acabou cedendo; ouviu as reivindicações da categoria e, no fim, apresentou uma proposta muito melhor do que a apresentada inicialmente. O movimento grevista e a ocupação do prédio público, então, se encerraram no dia 14 de novembro. Foram, nada mais nada menos, 53 dias de greve e que renderam, ao final, diversas conquistas para os professores e para a educação pública do Pará. Entre outras, garantia de $25 \%$ de jornada fora de sala de aula (ainda inferior ao 1/3 da Lei do Piso Salarial Nacional, mas já não mais 0\%); apresentação de um cronograma de reforma das escolas; promessa de elaboração e encaminhamento de um projeto de lei para eleição direta para diretores de escola em 30 dias e pagamento do adicional por titulação do professor, dispositivo previsto legalmente. A avaliação do sindicato é de que "este movimento foi dos mais radicalizados e figura como um dos mais vitoriosos em âmbito nacional" ${ }^{33}$.

A ocupação do local de trabalho pelos coletivos operários é, talvez, o ato mais radical de luta sindical. Como avalia Pinho Pedreira, uma "forma áspera de luta social" (1993, p. 93). Um ato complexo de realizar, porque difícil de ser apoiado pela maioria, pois parece, aos olhos dos trabalhadores, agressivo, violador demais. Requer muita união da classe, intensa vontade de abandonar a subserviência e de lutar ativamente por direitos. Entretanto, apesar dessa dificuldade, a greve com ocupação de locais de trabalho é "um fenômeno consolidado na sociologia das greves" (LÓPEZ-MONIZ, 1986, p. 50). Exatamente, talvez, porque a ocupação, quando feita com sucesso, é extremamente eficaz como meio de pressão e conquista de direitos, como foi no caso que narramos para abrir a discussão sobre este tema.

Neste tópico, abordaremos a primeira problemática jurídica enfrentada pelos trabalhadores nos processos de recuperação: a questão da licitude da greve de ocupação. Trataremos, em primeiro lugar, da ocupação passiva, que é aquela feita no

\footnotetext{
${ }^{33}$ Informações obtidas em pesquisa das notícias do portal virtual do Sindicato dos Trabalhadores em Educação Pública do Pará (http://www.sintepp.org.br/) e em outros portais de notícias (http://radioruraldesantarem.com.br, http://noticias.orm.com.br).
} 
âmbito da luta sindical tradicional, cuja intenção é apenas pressionar, e não controlar, a produção. E, depois, da ocupação ativa, que é a que nos interessa mais de perto, na qual o objetivo do coletivo operário é controlar, de alguma forma, os bens de produção. Demonstraremos que ambas as ações são legítimas perante a nossa ordem jurídica, se realizadas dentro de certas condições. A primeira, se realizada sem violência, por enquadrar-se na definição geral de greve, garantia pela Constituição e pela Lei n. 7.783/89. E a segunda, se realizada em reação a determinada conduta patronal socialmente lesiva e contrária a interesses coletivos, por importar em realização do princípio da função social dos bens de produção.

\subsubsection{Ocupar para pressionar em greves: expressão da autotutela laboral}

A greve é antes de tudo um fato social que a norma jurídica procura encarar e de certo modo domesticar.

Segadas Viana (apud AROUCA, 1988, p. 324)

De nada adianta a crítica desenvolver teorias sobre o abuso do direito de greve quando não se coíbe o abuso de negar ou restringir direitos, de extinguir postos de trabalho para tornar a empresa competitiva diante das concorrentes transnacionais.

José Carlos Arouca (1988, p. 382)

No ano de 2012, o DIEESE registrou que ocorreram 873 greves no Brasil (o maior número desde 1997). Desse total de mobilizações, pelo menos 64 contou com a realização, pelos trabalhadores, de medidas de ocupação ou suas similares, o acampamento e a vigília (DIEESE, 2013, p. 15); ou seja, em quase um décimo das greves realizadas no país neste ano houve a adoção de alguma dessas medidas pelos trabalhadores $^{34}$. É um número significativo. A verdade é que, como reconheceram os

${ }^{34}$ Vale dizer que, como avisa o próprio informe citado, a estatística do departamento sindical é 
juslaboralistas franceses Hélène Sinay e Jean-Claude Javillier em pesquisa sobre esse fenômeno, a greve com ocupação "se tornou uma prática frequente e, mesmo, cada vez mais frequente" (apud PEDREIRA, 1993, p. 93).

A maioria dessas ocupações, por certo, se constitui no que se costuma identificar como ocupação passiva: os trabalhadores permanecem ou ingressam no local de trabalho unilateralmente, com o objetivo de aumentar a pressão exercida sobre o empregador pela ação paredista. A intenção do ato, como indica Pinho Pedreira, é "endurecer e reforçar a greve, de modo a tornar mais fácil a conquista das reivindicações" (1993, p. 94). E também, conforme o juslaboralista e então perito da OIT Carlos López-Monís,

\begin{abstract}
garantir a eficácia da greve. Com a ocupação pretender-se-á evitar o trabalho dos 'fura-greves' contratados ou não-grevistas, defender simbolicamente o emprego frente a um possível lock-out, desenvolver um 'espírito coletivo' entre os grevistas, através de assembleias e comunicações entre eles que, de outro modo, não se poderia produzir, além do efeito-demonstração diante da opinião pública (1986, p. 50).
\end{abstract}

Eventualmente, esses conflitos chegam ao judiciário. E, então, caberá ao juiz intérprete decidir sobre sua licitude ou ilicitude.

A partir de uma leitura democrática e sistêmica da Constituição e da Lei de Greve, a conclusão a que se chega é de que a greve com medida de ocupação é lícita, se atender aos requisitos da ordem jurídica - em especial, o da pacificidade.

Em primeiro lugar, porque se trata de greve, não escapando às definições tradicionais desse instituto, inclusive a adotada pelo legislador brasileiro na Lei $\mathrm{n}$. 7.783/89. Dessa forma, a greve com ocupação permanece com a qualidade de "suspensão coletiva, temporária e pacífica, total ou parcial, de prestação pessoal de serviços a empregador" $\left(\operatorname{artigo} 2^{\circ}\right)$. E, portanto, ação coletiva operária protegida pela ordem jurídica. Em especial, pelo artigo $9^{\circ}$ da Constituição, que determina: "É assegurado o direito de greve, competindo aos trabalhadores decidir sobre a oportunidade de exercê-lo e sobre os interesses que devam por meio dele defender".

É esse o entendimento de Maurício Godinho Delgado, para quem "a ocupação do estabelecimento é, essencialmente, um método de realização do 
movimento paredista. Por isso, enquadra-se no conceito legal dessa figura do Direito Coletivo" (2001, p. 156). Continua o juslaboralista:

Conforme já debatido, a precedente Lei de Greve (n. 4.330, de 1964), oriunda de período autoritário da vida política do país, explicitamente subordinava o tipo-legal da greve à desocupação dos locais de trabalho - exigência que desapareceu com a nova ordem jurídica constitucional (art. $9^{\circ}, \mathrm{CF} / 88$ ) e legal (Lei $\mathrm{n}$. 7.783/89). O silêncio da nova ordem jurídica resulta no fato de não haver real comprometimento do instituto paredista em face da adoção da estratégia ocupacional, uma vez que esta mantém-se subordinada à função primária da figura grevista, que é a abstenção coletiva de atividades contratuais pelos trabalhadores (2001, p. 156).

Pinho Pedreira lembra que "há quem pense que a ocupação desqualifica a abstenção do trabalho como greve. A tese é refutada por vários eminentes doutrinadores, dentre os quais Sinay e Javillier" (1993, p. 102). Vale reproduzir o arrazoado da dupla francesa, que destaca, inclusive, ser indiferente que a ocupação resulte em deterioração da produção:

A greve com ocupação dos locais corresponde à qualificação de greve. É um meio de pressão manifestado por uma paralisação de trabalho, tendo em vista fazer vingarem reivindicações. A acentuação do meio de pressão que constitui a ocupação dos locais engendra apenas uma diferença de grau, não uma diferença de natureza entre essa greve e as outras. A nocividade resultante da deterioração total da produção é, também ela, inerente à greve. Não é suscetível de transformar uma greve lícita em ilícita. Enfim, a forma de greve é indiferente, desde quando a desorganização concertada da produção não seja excessiva (apud PEDREIRA, 1993, p. 102).

De maneira semelhante se posiciona o juslaboralista Jorge Luiz Souto Maior, para quem,

para fazer valer a vontade coletiva, os meios de persuasão pacífica, como o piquete e a ocupação, são plenamente legítimos, pois é da essência da efetividade desse direito que o empregador não pode manter em funcionamento sua atividade produtiva, normalmente, durante a greve (2012, p. 643).

No mesmo sentido, também, os uruguaios Francisco de Ferrari, segundo o qual, para a existência de greve, "não é indispensável o abandono dos lugares de trabalho, como se entendeu durante muito tempo" (apud PEDREIRA, 1993, p. 102); Ruben Caggiani, esclarece que

para que a ocupação dos lugares de trabalho não pudesse ser considerada modalidade do exercício do direito de greve seria 
indispensável que a noção da greve incluísse entre seus elementos essenciais o abandono do lugar de trabalho. Todavia, das distintas definições que a doutrina dá de greve nenhuma faz referência a este elemento (apud PEDREIRA, 1993, p. 102);

e, também, Jorge Seré:

importantes autores latino-americanos têm entendido que o só fato de que a suspensão de trabalhos se realize com ocupação de locais não basta para privar a greve de sua legalidade. Esta é uma suspensão de trabalho e se o legislador não previu a forma de executá-la mal se poderia distinguir onde a lei não distingue (apud PEDREIRA, 1993, p. 103).

Aqueles que são contrários a essa conclusão afirmam, como coloca Pedreira, que, não obstante, quando há ocupação do local de trabalho a greve se torna ilícita, porque atenta contra dois direitos fundamentais: o direito de propriedade e a liberdade de trabalho.

Os argumentos, entretanto, não convencem.

Acerca da alegação de ofensa à propriedade (que, muitas vezes, vem acompanhada da petulante afirmação de que o único título que legitima a presença dos trabalhadores no local de trabalho é a execução do trabalho prevista no contrato), importa citar a decisão de 22.2.1974 do Tribunal da Grande Instância de Paris, que representou um ponto de inversão da jurisprudência francesa no tratamento do tema. Tratava-se de um pedido ao judiciário de expulsão de grevistas do local de trabalho, e o tribunal julgou-o improcedente, assim fundamentando:

1) que, se a Constituição defende o direito de propriedade, defende igualmente o direito de greve; 2) que não existe, nestes casos, intenção real de ocupar (animus spoliandi), mas apenas de que a greve seja efetiva; 3) que não existe um atentado grave ao direito de propriedade (LÓPEZ-MONÍS,1986, p. 52).

A decisão, como se vê, é expressão de uma leitura não formalista da ordem jurídica, e prestigia o fato, simples, mas muito ignorado, de que o direito de propriedade não é absoluto e está inserido, como todos os demais direitos, num sistema normativo integral.

Menos consideração ainda merece o argumento da ofensa à "liberdade de trabalhar" (argumento muito usado, a propósito, em decisões judiciais brasileiras, 
provavelmente em razão do $\S 3^{\circ}$ do artigo $6^{\circ}$ da Lei de Greve ${ }^{35}$ ).

Os patrões alardeiam a existência desse "direito" quando empreendem atos de ataque às greves. Ora, mas a que liberdade e a que direito eles se referem? Os grevistas estão exercendo um direito constitucional democrático e reivindicam, em união, melhoras no salário e nas condições de trabalho que beneficiarão a todos. Mas e os fura-greves, o que fazem? Agem em prol de quê e de quem? Por acaso, se não ingressarem para trabalhar, perderão o emprego? Devemos saber que não se trata de proteger, aí, nem o direito constitucional à liberdade de trabalho, nem o direito constitucional de acesso ao trabalho. $\mathrm{O}$ direito à liberdade de trabalho, previsto no artigo $5^{\circ}$, XIII, da carta ("é livre o exercício de qualquer trabalho, ofício ou profissão, atendidas as qualificações profissionais que a lei estabelecer") refere-se à proibição do trabalho forçado e à liberdade, em tese, de toda pessoa se lançar no mercado a qualquer ofício não proibido em lei. E o direito de acesso ao trabalho do artigo $6^{\circ}$ (“São direitos sociais [...] o trabalho”) significa, como já expusemos, a garantia social de que todos terão acesso a um trabalho que permita viver dignamente. É muito evidente que nenhum desses direitos constitucionais têm relação com o ato do empregado que não adere à greve e que se relaciona, no máximo, a um descontextualizado "direito de livre locomoção".

A verdade é que, quando os empresários capitalistas lançam mão desse argumento, estão, de fato, defendendo o próprio direito de lucrar com o trabalho de seus empregados. Estão, como sempre, tentando minimizar, ao máximo, seus prejuízos. Usam a seu favor, com grande cinismo, a atitude de alguns indivíduos, pobres coitados, que, por medo, excessiva subserviência ou pela de crença egoísta de que mostrar obediência lhes renderá uma melhora de conceito com o patrão, rompem a união do coletivo operário. O judiciário, ao aceitar a tese de que o "direito dos não grevistas de trabalhar" importa em qualquer limitação ao direito constitucional de greve, está, de fato, alimentando o anseio insensível do capitalista em continuar explorando a mão de obra e lucrar sempre o máximo possível e, ao mesmo tempo, prestigiando a postura egoísta dos fura-greves, que rompem o espírito democrático da classe e enfraquecem a mobilização. E, tudo isso, em prejuízo das conquistas e direitos dos grevistas, trabalhadores organizados, que tomaram uma postura cidadã,

\footnotetext{
${ }^{35}$ Artigo $6^{\circ}, \S 3^{\circ}$, da Lei 7.783/89: "As manifestações e atos de persuasão utilizados pelos grevistas não poderão impedir o acesso ao trabalho em causar ameaça ou dano à propriedade ou pessoa".
} 
ativa e não aceitaram a absoluta submissão. Conquistas das quais, a propósito, os não grevistas também aproveitarão.

É certo que o $\S 3^{\circ}$ do artigo $6^{\circ}$ da Lei de Greve brasileira prevê que "as manifestações e atos de persuasão utilizados pelos grevistas não poderão impedir o acesso ao trabalho". Este é um dispositivo legal e não pode ser ignorado, deve ser considerado na interpretação do microssistema jurídico das greves. Entretanto, é uma mera regulação infraconstitucional e não pode, jamais, ser equiparada ao direito de greve garantido no artigo $9^{\circ}$ da Constituição. Sempre que essa proibição legal conflitar com o exercício do direito de greve, este segundo deve prevalecer, por simples aplicação da regra hermenêutica tradicional de hierarquia normativa. Isso significa, por exemplo, que, se a coletividade operária houver aprovado, em assembleia democrática, que a greve necessitará de um ato de ocupação para se tornar efetiva, a vontade de uns poucos empregados em "cumprir sua obrigação com o patrão" não deverá ser tomada como razão para se considerar a greve de ocupação como ilícita.

A questão da licitude da greve de ocupação, portanto, é questão de respeito à autotutela coletiva operária. Autotutela que foi claramente garantida pelo constituinte, que fez constar no artigo $9^{\circ}$ da carta que compete aos trabalhadores decidirem sobre a oportunidade de exercer o direito e sobre os interesses que devam por meio dele defender. Como pontua Delgado,

a greve é, de fato, mecanismo de autotutela de interesses; de certo modo, é exercício direto das próprias razões, acolhido pela ordem jurídica. É, até mesmo, em certa medida, 'direito de causar prejuízo', como indica o jurista Washington da Trindade (2001, p. 142).

Desse modo, se o coletivo, utilizando-se de seus mecanismos democráticos clássicos - a assembleia geral, em especial -, decide que a continuidade da greve necessitará de um piquete, uma vigília, um acampamento ou uma ocupação, essa decisão deve ser respeitada pelo judiciário e demais agentes estatais. A ofensividade faz parte do instituto da greve e será, a princípio, legítima se for expressão de uma decisão democrática dos trabalhadores. O instituto deve ser interpretado com esse pressuposto. Não tem sentido qualificar um movimento paredista como ilícito simplesmente porque causa prejuízo (por exemplo, porque impede o empregador de contratar mão de obra substitutiva), pois a greve é uma forma de luta e é como forma 
de luta, de instrumento nocivo, que está garantida na Constituição.

Assim, conclui-se que a greve de ocupação passiva - aquela que se faz apenas na intenção de aumentar a pressão sobre a patronal - será lícita como expressão da autotutela coletiva operária. Devendo atender apenas aos requisitos básicos de legalidade de qualquer greve, a saber: a não violência, o caráter coletivo, a abstenção de trabalho e o caráter provisório - artigo $2^{\circ}$ da Lei de Greve.

3.3.2 Ocupar para produzir: o papel decisivo da medida de ocupação nas recuperações operárias

No mercado humano capitalista, os trabalhadores são sacrificados num jogo financeiro que não controlam.

Trabalhadores da New Era Windows Cooperative (NEW ERA WINDOWS COOPERATIVE, 2013)

Nos primeiros meses de 2012, os trabalhadores da fábrica grega Vio.Me viviam uma situação complicada. Eles estavam sem trabalhar desde setembro do ano anterior, mês em que resolveram exercer seu direito de abstenção de trabalho por falta de pagamento ${ }^{36}$. Seu patrão já estava há cinco meses sem pagar os salários em conformidade com o contrato de trabalho. Pagava com atraso e em valores menores. Por isso a decisão de setembro. $\mathrm{O}$ ano virou, entretanto, e eles continuaram sem definições, ficando numa condição cada vez mais desesperadora, com a fome batendo à porta. O país passava pela fase mais aguda da crise econômica mundial detonada em 2008, com a taxa de desemprego em 27\%. E os patrões não mostravam nenhuma intenção real de retomar a produção. Em julho de 2012, então, reunidos em assembleia, os operários decidiram: retomaremos a produção nós mesmos. A decisão

\footnotetext{
${ }^{36}$ Trata-se de um direito trabalhista grego, "epishesi ergasias": direito de se abster de trabalhar no caso de atraso no pagamento de salários.
} 
foi quase unânime, $98 \%$ de aprovação. Mas, a partir desse momento, outra preocupação surgiu. Para retomar a produção, a fábrica precisaria estar íntegra. Assim que os patrões soubessem da decisão, certamente iriam tentar salvar seu patrimônio. Por isso, a assembleia decidiu que eles deveriam tomar as ações necessárias para proteger as máquinas que, agora, eram sua esperança de sustentar suas famílias. Decidiram romper os cadeados dos portões e ocupar a fábrica e 40 trabalhadores se dispuseram a "fazer um revezamento por turnos para assegurar que nenhum equipamento fosse removido pela administração ou roubado" 37 (ED, 2012). A ocupação chegou ao judiciário, que, para alegria dos trabalhadores, lhes deu razão (THE CLINIC ONLINE, 2013). Sete meses depois, em 12 de fevereiro de 2013, após muita luta e apoio solidário da classe trabalhadora internacional, a Vio.Me reabriu sob controle operário, ofertando ao mercado seu cimento, argamassa, rejunte e outros materiais de construção e garantindo para seus trabalhadores e suas famílias o acesso à renda e, com ela, à dignidade.

Nem todas as recuperações operárias de empresas têm uma medida de ocupação forçada no início de sua trajetória. Cada caso tem sua peculiaridade e, em muitos deles, como já mencionamos, o reingresso na fábrica só ocorre após uma autorização judicial (caso do ingresso da Cocepelco, na falida Nobrecel, em 2013, em Pindamonhangaba-SP) ou após a finalização de uma negociação direta com os patrões (caso da Makerly, em 1991, em Franca-SP). Isso não significa que não houve conflitos no processo. No caso da Cocepelco, por exemplo, os operários realizaram manifestações públicas, uma delas com o fechamento de ruas às portas do fórum da cidade, ação feita para pressionar o judiciário a aceitar o pedido de continuação operária. E, no caso da Makerly, houve um processo de mobilização intensa de 91 dias de pressão para que a negociação se desenvolvesse, com ponto culminante na ocupação da sede do Banco Banespa da cidade de Franca (SINGER, 2012, p. 88). Quaisquer operários que desejem retomar a produção da empresa para sobreviver devem saber que não conseguirão sem luta.

Não por acaso a palavra de ordem que acabou sendo abraçada pelos movimentos de recuperação operária de empresas de todo o mundo, "Ocupar, Resistir, Produzir!”, se inicia pelo verbo “ocupar”. É fato que, em parte significativa

${ }^{37}$ Tradução livre de: " 40 workers all of which are, to date (one year after the closure of the factory) active, taking shifts at the factory to ensure that no equipment is removed by the administration or stolen". 
das recuperações, a ocupação unilateral da planta pelos trabalhadores acontece e é decisiva para o sucesso da retomada.

No Brasil, dentre as ERTs que estão ativas atualmente, em 32\% delas houve necessidade de ocupação ou acampamento no início do processo (HENRIQUES et al. 2013, p. 57-8); ou seja, aproximadamente uma em cada três. Nesses casos, como ocorreu no caso da Vio.Me, em certo momento, o coletivo operário percebeu que a ocupação seria necessária e decisiva para a retomada da produção pelos trabalhadores.

A ocupação da empresa não é um luxo, mas uma necessidade que, às vezes, se coloca para os trabalhadores que se recusam a aceitar as determinações insensíveis da economia capitalista e decidem ir até o fim para concretizar seu direito de trabalhar e viver com dignidade. E, nesses casos, trata-se do primeiro passo efetivo executado pelo trabalhador no sentido de abandonar a posição de controlado e encarar o desafio de ser um controlador.

3.3.3 A função social dos bens de produção como parâmetro: análise à luz da Teoria dos Direitos Fundamentais

Ocupações como as das ERTs brasileiras e a da grega Vio.Me diferem fundamentalmente das que tratamos no tópico anterior, pois seu objetivo não é aumentar a pressão de uma greve para fortalecer as reivindicações de melhora de condições de trabalho. Seu objetivo, bastante diverso, é o de tomar, de alguma forma, o controle da produção. São as chamadas, pela doutrina, ocupações ativas ${ }^{38}$. Como

\footnotetext{
${ }^{38}$ Devemos saber que nos casos concretos não é tão simples classificar uma ocupação como passiva ou ativa. A verdade é que, em geral, nas trajetórias das ERTs existentes, as ocupações se iniciaram sem intenção de retomar a produção. Como ocorreu, por exemplo, nos casos da Cipla, de Joinville-SC, em 2002; da Flaskô, de Sumaré-SP, em 2003; e da New Era Windows, de Chicago/EUA, em 2008 e 2012. E, também, no antigo e importante caso da Lip, de Besancón/França, em 1973. Nessas experiências, os grupos de trabalhadores, cada qual em seu contexto, se lançou inicialmente à ocupação para pressionar o patrão por reivindicações tipicamente trabalhistas, em especial pela manutenção dos empregos, que eram ameaçados. Ocupações, portanto, de caráter passivo, segundo a classificação
} 
explica Pedreira,

as ocupações ativas são aquelas em que, independentemente da vontade do empregador e até mesmo quando manifestada em seu sentido contrário, os trabalhadores continuam a prestar serviços, assumindo a gestão da empresa, com o objetivo de impedir o encerramento desta ou a redução de suas atividades, de modo a garantir a conservação dos empregos (PEDREIRA, 1993, p. 98).

Identificar se a ocupação é passiva ou ativa é relevante porque o tratamento jurídico desses dois tipos de greve deve ser absolutamente diverso. Os parâmetros tradicionais - e, em especial, a Lei n. 7.783/89 - não servem para avaliar e qualificar uma greve com ocupação ativa. Por uma razão simples: o ponto temático da ordem jurídica sobre o qual incide o conflito já não é, nesses casos, o contrato de trabalho assalariado, com suas questões relacionadas ao direito de negociação do coletivo operário (fundamento do direito de greve) e ao valor das verbas salariais e condições de trabalho fornecidos pelo empregador. Nenhuma questão trabalhista tradicional entra em questão.

De fato, o ponto temático em que incidem os conflitos surgidos nos casos de ocupação ativa, o questionamento emergente, é fundamentalmente outro: a legitimidade do controle dos bens de produção exercido pelo empresário, em razão do cumprimento ou não de sua função social.

Ocupações ativas não acontecem repentinamente, devemos saber. Todas as greves com ocupação ativa que já foram deflagradas ocorreram num contexto específico, um contexto de crise econômica aguda no interior da empresa e ruptura dos padrões e funções que dela são esperados. Como explica o espanhol PerroteEscartin,

a razão fundamental que move os trabalhadores nos exemplos contemporâneos mencionados a recorrer à greve com ocupação do lugar de trabalho se apresenta empiricamente na realidade europeia atual como um meio de oposição a pretensos expedientes de crise que provocam despedidas ou, mais frequentemente, em face de projetados fechamentos definitivos de empresas que são o suporte econômico fundamental de uma localidade, ou de uma região (apud PEDREIRA, 1993, p. 94).

É o que demonstram os dados colhidos no mapeamento brasileiro. Em quase

doutrinária. No entanto, em todos esses casos, as condições levaram os coletivos operários, em certo momento, a desacreditarem numa solução por parte dos empresários, mudarem seu foco e passarem a buscar de alguma forma o controle da produção. 
todas as ERTs brasileiras (81\%), o início do processo de recuperação (nem todos com ocupações, lembremos) se deu em meio a crise financeira, falência ou fechamento. E diversos outros problemas críticos estiveram presentes, como falta de pagamento de salários, má gestão do negócio, dívidas com fornecedores, alienação clandestina do maquinário, demissões, dívidas tributárias e problemas judiciais com relação aos donos (HENRIQUES et al., 2013, p. 46). Some-se a isso o fato de que, na maioria dos casos, há também uma crise econômica externa à empresa, o que acentua a pressão sobre os trabalhadores no sentido de serem reduzidas as chances de conseguir outra fonte de sustento.

Isso significa que é um grande equívoco analítico afirmar, simplesmente, que as ocupações são ilegais porque ferem o direito de propriedade, num raciocínio que siga, mais ou menos, essa linha: a empresa é do dono; eles não são donos; então estão lá ilicitamente. Essa síntese frágil, absolutamente descontextualizada, não serve em nada na busca de soluções para os casos de ocupação ativa. Nem mesmo para os patrões, vale dizer, que, nesses contextos, buscam justamente argumentar que sua propriedade deve ser protegida, porque cumpre função social (em defesa de seu patrimônio eles citam, por exemplo, quantos empregos os bens de produção sob seu controle já geraram e poderão gerar, e tentam explicar que o valor poderá ser reinvestido em outra atividade produtiva, mais benéfica a todos).

Ora, os trabalhadores tomam o controle dos bens de produção justamente apoiados no pensamento de que, nas mãos do empresário capitalista, eles não estavam funcionando como se espera, não estavam gerando trabalho e renda como deveriam gerar. Em outras palavras, que eles não estavam cumprindo sua função social. E, ao mesmo tempo, no pensamento de que, em suas mãos coletivas, referidos bens gerarão trabalho e renda; e, ainda, de uma forma melhor, com mais benefícios à comunidade local e à sociedade, do que trazia enquanto nas mãos do capitalista. Em outras palavras: os bens de produção cumprirão sua função social.

Assim, o tema em questão não é a propriedade ou a posse, mas, sim, a função social dos bens de produção.

Esse é o tema jurídico e o intérprete não pode se furtar a enfrentá-lo, “fingindo" que se trata de uma questão possessória. Não pode, em especial, porque nossa ordem jurídica é muito clara no sentido de que a propriedade dos bens de 
produção deve cumprir sua função social. Isso decorre da presença conjunta dos incisos II e III no artigo 170 da Constituição ${ }^{39}$, instituidor de nossa ordem econômica.

Então, mesmo que seja para negar a licitude da ocupação produtiva, o analista jurídico deve fazê-lo considerando o papel central do princípio da função social da propriedade dos bens de produção no conflito.

Definida essa necessidade, então, verificamos que, para a análise da licitude da greve com ocupação ativa do local de trabalho, o agente jurídico deve enfrentar dois pontos: em primeiro lugar, saber se o ato se qualifica como uma greve (e, portanto, recebe proteção constitucional); e, em segundo, se, e em que condições, o ato será lícito, a partir de uma leitura que considere a influência do princípio constitucional da função social da propriedade dos bens de produção.

Postos esses pontos, demonstraremos, nas próximas linhas, que a ação coletiva operária de ocupar o local de trabalho com o objetivo de produzir se trata de greve, de acordo com o moderno conceito de greve como recusa coletiva de trabalho subordinado. E será lícita se atender à condição de ser realizada em reação a determinada conduta patronal socialmente lesiva e contrária a interesses coletivos, por importar em realização do princípio da função social dos bens de produção.

Em primeiro lugar, deve-se reconhecer que a greve com ocupação para produzir é modalidade de greve aceita por nossa ordem jurídica.

Isso porque o fundamento do direito de greve de nossa ordem jurídica - o artigo $9^{\circ}$ da Constituição - a abarca em sua definição. Como pontua Maurício Godinho Delgado,

\footnotetext{
o texto constitucional de 1899 firma, sem dúvida, extensão bastante larga para o direito de greve no segmento privado. Diz a Constituição que compete aos trabalhadores decidir sobre a oportunidade de exercer o direito e sobre os interesses que devam por meio dele defender (art. $9^{\circ}$, caput). Trata-se, sem dúvida, da mais ampla potencialidade reconhecida ao instituto em sua vivência no país (2001, p. 158).
}

\footnotetext{
39 “Art. 170. A ordem econômica, fundada na valorização do trabalho humano e na livre iniciativa, tem por fim assegurar a todos existência digna, conforme os ditames da justiça social, observados os seguintes princípios: [...] II - propriedade privada; III - função social da propriedade”.
} 
O texto constitucional, portanto, elaborado justamente com a intenção de prestigiar todas as formas de ação coletiva laboral de luta por direitos, não restringiu o instituto pela adoção de uma definição fechada.

A ocupação ativa, portanto, como ação coletiva operária de luta por direitos, é modalidade de greve. Não é outra a conclusão de Pinho Pedreira, que, rebatendo sua objeção mais comum, arrazoa:

Há quem, apegado à noção tradicional de greve, como tal não considere a ocupação ativa de locais de trabalho porque, nela, existe constante continuação da atividade produtiva. Mas o conceito de greve como abstenção do trabalho é um conceito em crise, porque divorciado da presente realidade social, que oferece exemplos de greves sem paralisação de serviço, como as de zelo, de rendimento etc., e não só o das greves ativas (1993, p. 98).

O autor cita as definições de greve dos franceses Sinay e Javillier, segundo os quais a greve é "um meio de pressão para fazer vingarem reivindicações que se manifestam por uma recusa coletiva de trabalho subordinado"; do espanhol Luís Enrique de La Villa, que engloba no conceito de greve da constituição espanhola "todas as hipóteses nas quais, sem cessação real e concertada do trabalho, se empreendem atos coletivos que perturbam a normalidade e/ou continuidade do processo produtivo"; e do também espanhol Perrote-Escartin, que caracteriza a greve como ato de "ruptura do cotidiano" e "perturbação do processo produtivo", de modo que "a ocupação ativa configurar-se-ia, neste sentido, como uma greve ativa, denominação já incorporada a certa linguagem doutrinária, política e sindical" (apud PEDREIRA, 1993, p. 98-9).

Concluímos, com isso, que o artigo $9^{\circ}$ da Constituição protege a prática de duas espécies diferentes de greve: a greve passiva, de objetivos meramente reivindicatórios, regulada pela Lei n. 7.783/89; e a greve ativa, ação operária de ocupação produtiva do local de trabalho (usamos, com isso, a nomenclatura que, conforme Perrote-Escartim, já se consolidou).

Chegamos, então, à interrogação sobre os parâmetros que devem ser utilizados para avaliar a licitude de uma greve ativa.

De início, é imperativo concluir que a chamada Lei de Greve brasileira (a Lei n. 7.783/89) não nos serve. Ocorre que esta lei e seu complexo normativo consideram tão somente a realidade das modalidades de greve passiva, regulando 
temas como a manutenção de serviços essenciais (artigos $9^{\circ}$ a 13) e a proibição às empresas de adotar meios de constranger os empregados a comparecerem ao trabalho $\left(\S 2^{\circ}\right.$ do artigo $\left.6^{\circ}\right)$. Temas que são absolutamente estranhos às greves ativas. Esta lei não foi elaborada com pensamento nesta nova modalidade de greve que se consolida na contemporaneidade, a greve ativa; e, exatamente por isso, não serve para solucionar os problemas jurídico-sociais que emergem desse fato. Portanto, não pode ser utilizada para enfrentamento das questões jurídicas emergentes desses casos, a não ser de forma subsidiária, em um ou outro ponto servível. Carece de legitimidade, portanto, qualquer análise da licitude de uma greve ativa fundamentada na Lei n. $7.783 / 89$.

Para as greves ativas, portanto, na falta de legislação específica, devemos recorrer ao texto constitucional e, eventualmente, ao direito coletivo do trabalho, ao direito civil comum e ao direito comparado, até que seja editada norma infraconstitucional regulando a matéria. Método, a propósito, que é o comum no tratamento jurídico de fenômenos sociais novos ${ }^{40}$.

Nessa esteira, os principais dispositivos da ordem jurídica que devem orientar tal enfrentamento estão na Constituição. São eles: o princípio do direito de propriedade privada de bens de produção (artigo 170, II); o princípio da função social da propriedade de bens de produção (artigo 170, III); o princípio do direito ao trabalho (artigo $6^{\circ}$ ); e o princípio do valor social do trabalho e da livre iniciativa (artigo $1^{\circ}$, IV, e 170, caput).

São esses os dispositivos porque eles constituem a base positiva constitucional que sustenta a legitimidade do controle empresarial de bens de produção. E, como já dissemos, quando ocorre a greve ativa, os conflitos emergentes se articulam justamente em torno desse ponto temático da ordem jurídica, com a questão do cumprimento ou não da função social da propriedade produtiva.

Quando operários ocupam ativamente uma empresa é em torno dessa legitimidade que se dão os debates nos jornais, nos corredores da fábrica e na comunidade. Ou seja, na arena econômica e social. E esses debates vinculam, necessariamente, o debate jurídico, que não pode se furtar a olhar para a realidade.

40 Vale mencionar que no Uruguai, país vizinho que também presencia um forte movimento de recuperações operárias, já foi editado o primeiro diploma normativo com esse objetivo, o Decreto $\mathrm{n}$. 165/2006. Traremos esse fato para a análise mais à frente. 
Postas essas premissas, temos condições de avaliar se, e em que condições, a greve ativa é lícita. Para isso nos utilizaremos do método da máxima da proporcionalidade segundo a Teoria dos Direitos Fundamentais, do alemão Robert Alexy. Além disso, desenvolveremos, também, a elaboração sobre o princípio da função social da propriedade que iniciamos em um tópico anterior (item 3.1). Vale repisar que a adoção da teoria de Alexy, respeitada internacionalmente, se justifica porque é útil e benéfica por fornecer um parâmetro metodológico estruturado que permite um debate racional sobre o problema.

O método de Alexy é aplicável ao caso porque emerge, nos contextos em análise, uma colisão de princípios. Vejamos.

As greves ativas, como já narramos, acontecem num contexto de crise aguda. A empresa não fatura o suficiente, está afogada em dívidas, e o administrador demite grupos inteiros e atrasa salários. Passam-se meses, muitas vezes anos de agonia. E, então, em certo momento, os trabalhadores, em ato coletivo, decidem fazer a ocupação, ou, se a ocupação já existia, decidem por mudar seus objetivos, transformando-a numa ocupação ativa.

Há um conflito judicial básico que pode surgir dessa ocupação - como aconteceu, por exemplo, no caso da grega Vio.Me. O empresário ajuíza ação possessória, requerendo uma ordem de desocupação forçada dos operários. O coletivo operário, por sua vez, defende-se na ação, requerendo o indeferimento do pedido patronal e, consequentemente, a manutenção da ocupação ativa.

O fato é que tanto a decisão pela desocupação quanto a decisão pela manutenção da ocupação são suportadas por princípios constitucionais.

Há dois princípios que, se considerados isoladamente, importariam numa obrigatória conclusão de procedência do pedido e consequente desocupação. Em primeiro lugar, o princípio do direito de propriedade privada de bens de produção (artigo 170, II), segundo o qual apenas titular do bem decide sobre seu uso e disposição. E, em segundo, o princípio da função social da livre iniciativa (artigo $1^{\circ}$, IV e 170, caput), que importa numa valorização da iniciativa empreendedora inicial e, com ela, da conclusão de que qualquer iniciativa econômica pode falir e, por isso, o empresário não pode perder o controle de seu patrimônio apenas por essa razão. 
Por outro lado, há três princípios que, se considerados isoladamente, obrigariam o julgamento de improcedência e a manutenção da produção operária. O princípio do direito ao trabalho (artigo $6^{\circ}$ ), tendo em vista que greve ativa representa a manutenção imediata e inadiável das fontes de trabalho e renda, até então prejudicadas ou ameaçadas. O princípio do valor social do trabalho (artigo $1^{\circ}$, IV e 170, caput), que importa na valorização do fato de que a crise não pode ser imputada aos trabalhadores, que não gerenciavam a empresa e, portanto, não podem ser prejudicados pela falência. E, por último, o princípio da função social da propriedade de bens de produção (artigo 170, III), que prestigia a ocupação como via imediata de continuação da produção dos bens, da fonte de geração de renda e da movimentação da economia; em outras palavras, de realização do princípio da função social da propriedade de bens de produção.

Todas essas cinco normas são princípios e não regras. Isso porque não são normas de realização determinável, "normas que são sempre ou satisfeitas ou não satisfeitas" (ALEXY, 2006, p. 91). Pelo contrário, são normas de realização indeterminável, "caracterizadas por poderem ser satisfeitas em graus variados" (ALEXY, 2006, p. 90). Isso é claro para todas elas: não é possível, por exemplo, afirmar em absoluto se a norma do direito ao trabalho está ou não está sendo satisfeita olhando-se para determinado caso concreto (com é possível, por exemplo, para uma norma que obriga o depósito de FGTS no valor de $8 \%$ do salário). Mas elas são, ainda assim, normas jurídicas e, portanto, vinculantes.

De acordo com Alexy - e esta uma de suas inovações - a presença de princípios na ordem jurídica significa que seus conteúdos devem ser realizados "na maior medida possível dentro das possibilidades jurídicas e fáticas existentes”. Em outras palavras, os princípios são "mandamentos de otimização" do sistema (ALEXY, 2006, p. 90). Ou seja: se o estado, com seu poder de legislar, positivou normas de realização indeterminável como a do inciso IV do artigo $1^{\circ}$ da Constituição ("os valores sociais do trabalho e da livre iniciativa são fundamentos da República Federativa do Brasil"), seu significado é o de que os agentes estatais (políticos e jurídicos-políticos) devem agir no sentido de fazer com que essa norma se torne realidade na vida social na maior medida possível. E a maior medida possível é determinada pelas "possibilidades jurídicas e fáticas existentes". Ou seja, pelas demais normas do sistema que convivem com este princípio (princípios e 
regras colidentes), e pelos meios de realização existentes e disponíveis no mundo real (econômico, social, tecnológico, psicológico, cultural etc.). Assim, por exemplo, de acordo com a hermenêutica sistematizadora de Alexy, seria impossível tomar o princípio do direito ao trabalho da Constituição (artigo $6^{\circ}$ ) como um mandamento para que o estado garantisse em absoluto trabalho com salário digno para todos os que o procurassem, fornecendo, em última instância, um emprego público para aqueles que não estivessem empregados no setor privado. Juridicamente, porque, mesmo que se admita que este seja um meio adequado e eficaz de realizar "na maior medida possível" o princípio, ele colidiria com outros princípios da Constituição que não podem ser anulados (em especial, o da livre iniciativa capitalista - artigo 170, caput - que exige a existência de uma reserva humana de mercado). E, além disso, materialmente, porque, na verdade, esse não é um meio nem adequado nem eficaz de realizar esse princípio; pois, tendo em vista que, continuando a organização de trabalho baseada na separação entre gestores e subordinados, continuará sendo necessária a existência de um sistema de mercado de reserva humana para funcionamento da produção (e, portanto, para a garantia material da vida humana); uma tentativa intransigente do governo nesse sentido, portanto, resultaria em um colapso econômico muito antes de se conseguir dar um jeito de ocupar a todos ${ }^{41}$.

Portanto, afirmar que os princípios são mandamentos de otimização implica, em especial, a "inexistência de relação absoluta de precedência" entre eles (ALEXY, 2006, p. 99). Sendo assim, implica que não há hierarquia rígida entre princípios, de modo que, numa análise descontextualizada (ou seja, que não olhe para um caso concreto, mas para a lei em geral), não se pode dizer que um está acima do outro.

Os cinco princípios constitucionais em discussão, portanto - direito de

\footnotetext{
${ }^{41}$ Essa nossa interpretação, vale dizer, decorre de uma leitura heterodoxa de Marx, que recusa o estatismo (que foi encampado por marxistas reconhecidos, como Lênin, Trotsky e Gramsci). Leitura defendida, por exemplo, pelos franceses Yvon Bourdet, e Alain Guillerm (1976); pelo português João Bernardo (1999; e, também, "Democracia totalitária: teoria e prática da empresa soberana", editado no Brasil pela Cortez); e, em certa medida, pelo brasileiro Paul Singer (1998; 1999; 2008). Nosso ponto é que essa hipotética ação estatal que mencionamos não só seria politicamente impossível, por colidir diretamente com o fundamento de existência do estado burguês, de funcionalização do modo de produção capitalista; mas, mais importante, de maneira nenhuma é um caminho que devemos desejar tentar. Como já expusemos em outros momentos, é ilusão acreditar que a via para superação da barbárie do capitalismo é qualquer ação estatal pura, qualquer "solução por decreto". Não é possível acabar com o sistema de mercado de reserva, por exemplo, senão pela via econômica. O que determina fundamentalmente a forma da vida social humana é a forma de organização do processo produtivo. Por isso, apenas outra forma de organização desse processo, diferente da capitalista, poderá revolucionar a forma de vida social.
} 
propriedade, valor social da livre iniciativa, valor social do trabalho, direito ao trabalho e função social da propriedade - não têm, nenhum deles, mais importância abstrata que o outro.

Isso significa que o analista do caso não pode solucioná-lo simplesmente afirmando, por exemplo, que "o direito ao trabalho é o mais importante dos cinco, e, por isso, a ocupação deve continuar". Ou, então, que "o direito de propriedade é essencial e sagrado, e, por isso, o pedido deve ser deferido". Da doutrina de Alexy, portanto, retiramos uma lição importante: toda interpretação de normas deve considerar o sistema normativo como um todo, pois todas as normas positivadas pelo estado são válidas e vinculantes. Trata-se de uma visão sistêmica da ordem jurídica.

Portanto, tomando os princípios como mandamentos de otimização, o intérprete deve considerar, na solução para cada caso, a influência de todos os princípios incidentes. E considerar que, no "querer" da ordem jurídica, cada um deve ser garantido na maior medida possível. Afinal, a Constituição protege e garante tanto o direito de propriedade, quanto o direito ao trabalho, quanto a livre iniciativa, quanto a função social da propriedade. Não se pode negar isso em qualquer interpretação.

Então, à luz da Teoria dos Direitos Fundamentais, como realizar essa interpretação?

Retomando o que dissemos acima, sabemos que, se apenas dois princípios forem considerados (direito de propriedade e valor social da livre iniciativa), a solução é a desocupação. Mas, se apenas os outros três forem considerados (direito ao trabalho, valor social do trabalho e função social da propriedade), a solução é, pelo contrário, a manutenção da greve ativa.

Isso significa, conforme a teoria alexyana, que temos uma colisão de princípios: "algo é proibido de acordo com um princípio e, de acordo com o outro, permitido" (2006, p. 93). No caso, a ocupação é proibida de acordo com os dois primeiros princípios, e permitida de acordo com os outros três.

Para decidir qual dos dois lados deverá prevalecer, o intérprete deve analisar qual dos lados tem mais "peso" no caso concreto que se analisa, aplicando o reconhecido método da máxima da proporcionalidade, “com suas três máximas 
parciais da adequação, na necessidade (mandamento do meio menos gravoso) e da proporcionalidade em sentido estrito (mandamento do sopesamento propriamente dito)" (2006, p. 116-7). Método que, segundo Alexy, "decorre logicamente da natureza dos princípios" como mandamentos de otimização (2006, p. 117).

A máxima da proporcionalidade pressupõe que os princípios, como mandamentos de realização indeterminável, podem ser afetados ou satisfeitos em maior ou menor grau. Ou seja, não basta saber, por exemplo, que o princípio do direito de propriedade foi violado em um caso; é necessário saber em que contexto essa violação ocorreu, para saber se ele foi muito ou pouco violado. Nesse sentido Alexy sugere, para utilização prática, uma escala de três níveis para a avaliação desses graus: "leve", "moderado" e "elevado" (2006, p. 593-5) ${ }^{42}$. Assim, por exemplo, a ocupação de um terreno urbano vazio há 10 anos implicaria numa afetação "leve" do direito de propriedade do dono em comparação com a ocupação de uma casa construída cujo dono está ausente em razão de uma viagem de férias, uma afetação muito mais "séria", ou "elevada", desse direito. Há, nos dois casos, afetação do princípio; entretanto, a primeira é bem mais leve, pelas condições concretas em que ocorre, que a segunda. No mesmo sentido, uma ofensa feita "entre quatro paredes" por um chefe contra seu subordinado é uma afetação leve da dignidade do empregado se comparada a uma humilhação pública, feita em redes sociais ou por meio de um jornal, ação que afeta a dignidade do empregado, ofendido em maior grau.

Essa diferença de grau, segundo a teoria de Alexy, não pode ser ignorada pelo intérprete. Pelo contrário, ele deve considerá-la sempre que, nos casos em exame, houver princípios antagônicos.

Por isso, o primeiro passo da máxima da proporcionalidade em sentido

\footnotetext{
${ }^{42}$ Vale mencionar que esse "escalonamento triplo está longe de uma metrificação das intensidades de intervenção e dos graus de importância por meio de uma escala cardinal como, por exemplo, 0 a 1 . E isso tem que ser assim, porque as intensidades de intervenção e os graus de importância não são passíveis de serem metrificados com o auxílio de uma escala desse tipo". De fato, temos que reconhecer que não é possível hierarquizar os conflitos da vida humana numa escala absoluta. Como prossegue Alexy, "com certa frequência a simples classificação como leve, mediano ou sério já cria problemas. [...] Por isso, escalonamentos jurídicos só são possíveis com limiares relativamente rudimentares, e isso nem mesmo em todos os casos" (ALEXY, 2006, p. 603). A intenção de Alexy, deve-se saber, não é construir um método de solução absoluta de conflitos, mas, sim, um erigir um parâmetro metodológico que permita um debate racional; nas palavras de Alexy, permita a condução de enunciados de preferência que podem ser fundamentados de forma racional (2006, p. 165). Sobre isso, vide os tópicos da obra denominados "A ideia de sopesamento" (p. 163-76) e "Sistema jurídico e argumentação no âmbito dos direitos fundamentais” (p. 543-74).
} 
estrito - ou lei do sopesamento - é analisar qual será o grau de satisfação e nãosatisfação (afetação) dos princípios colidentes no caso de se optar por uma ou outra solução. E, então, decidir-se pela solução em que o grau da satisfação dos princípios favorecidos naquelas condições justifique o grau de afetação dos princípios desfavorecidos (ALEXY, 2006, p. 593).

Em outras palavras, dever-se-á escolher a solução que implicar numa satisfação "elevada" de certo princípio, em contrapartida a uma afetação "leve" do princípio colidente, naquelas condições concretas. Ou, na expressão mais sintética de Alexy, "um dos princípios tem precedência em face do outro sob determinadas condições" (2006, p. 93).

Desse modo, aplicar a Teoria dos Direitos Fundamentais aos casos de greve ativa significa analisar se, nas condições concretas de cada caso analisado:

a) A manutenção da ocupação importará num grau de satisfação dos princípios do direito ao trabalho, do valor social do trabalho e da função social da propriedade "elevado" e, em contrapartida, num grau de afetação dos princípios do direito de propriedade e do valor social da livre iniciativa "leve".

b) Ou, ao contrário, a desocupação importará num grau de satisfação dos princípios do direito de propriedade e do valor social da livre iniciativa “elevado" e, em contrapartida, numa grau de afetação dos princípios do direito ao trabalho, do valor social do trabalho e da função social da propriedade "leve".

No primeiro caso a ocupação deverá ser mantida, pois a alta satisfação dos princípios de um lado justifica a baixa afetação dos princípios do outro. No segundo, deve-se decidir pela desocupação, pelo mesmo raciocínio, aplicado inversamente.

Em palavras menos precisas, a tarefa é examinar se, em cada caso concreto, "pesa mais" promover os primeiros princípios em prejuízo dos últimos, ou, pelo contrário, promover os últimos em prejuízo dos primeiros.

Vemos que a decisão jurídica (como toda decisão baseada no método da máxima da proporcionalidade segundo Alexy) depende de um exame da satisfação e afetação dos princípios em relevo nas condições determinadas de cada caso 
concreto.

E, portanto, se queremos elaborar uma regra geral a partir dessa teoria (ou seja, estabelecer uma resposta geral acerca de sua licitude), devemos desenhar contextos possíveis, aplicar o método a cada um deles e, então, estabelecer parâmetros de caracterização de condições gerais em que prevalecem os princípios de um lado ou de outro.

Diante dessa exposição, temos as premissas necessárias para construir a resposta acerca da licitude da greve ativa.

Conhecendo a realidade dos conflitos capital-trabalho - tanto os conflitos sindicais tradicionais quanto, e principalmente, os crescentes conflitos pelo controle da produção - podemos deduzir que há três contextos diferentes que devem ser considerados para esta análise jurídica.

Os contextos diferem entre si quanto à postura do empresário na qualidade de controlador e gestor dos bens de produção. E são escalonadas no sentido de suas ações serem mais ou menos condizentes com o que a ordem jurídica espera de sua posição. Para essas três análises, consideraremos que estão presentes dois pressupostos. Primeiro, que a gestão operária empresarial nos três contextos é suficientemente eficaz e, por isso tem potencial razoável de gerar trabalho e renda para os participantes ${ }^{43}$. Por isso, a manutenção da ocupação é um meio adequado para a realização dos princípios favoráveis; e está satisfeito, portanto, o primeiro passo do método: a máxima da adequação, referente às possibilidades fáticas de

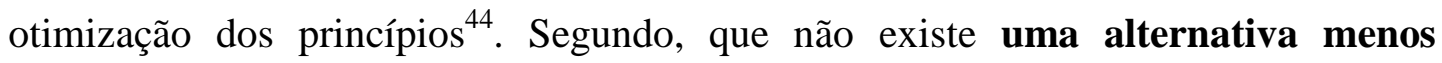
gravosa que a manutenção da ocupação ativa para realizar os três princípios (menos gravosa no sentido de ofensividade aos princípios opostos), ou seja, está satisfeito o segundo passo do método, a máxima da necessidade, também referente às possibilidades fáticas de otimização dos princípios $^{45}$.

\footnotetext{
${ }^{43}$ Sobre a questão da eficácia da gestão operária em recuperações como meios de geração de trabalho e renda, vejam-se as considerações que tecemos no tópico 3.1.4.

${ }^{44}$ A máxima da adequação consiste num exame, que deve preceder o sopesamento, cujo objetivo é verificar se as soluções postas em jogo são, realmente, meios de satisfação dos respectivos princípios. Como explica Alexy, "essa máxima tem, na verdade, a natureza de um critério negativo. Ela elimina meios inadequados" (2006, p. 590).

45 A máxima da necessidade, como coloca Alexy, "exige que, dentre dois meios aproximadamente adequados, seja escolhido aquele que intervenha de modo menos intenso" (2006, p. 590).
} 
Importa frisar que a análise que faremos consiste num esforço de criação de parâmetros gerais de avaliação do problema. Isso significa que a utilização deste estudo para solucionar casos concretos não prescinde de exames específicos que considerem as colisões dos princípios em cada conjunto de condições determinado, pois a metodologia alexyana é, por excelência, voltada à solução de casos concretos.

Passemos, então, à caracterização e exame de cada um dos três contextos.

\section{Contexto 1}

O primeiro contexto consiste numa deflagração de greve ativa em reação a um conflito de intensidade comum do processo empresarial capitalista. Esse pode ser definido como um conflito derivado de atos empresariais levemente antissociais ou ilegais - ou seja, atos contrários aos interesses operários, mas que não implicam numa violação grave às responsabilidades sociais estabelecidas pela ordem jurídica para o controlador de bens de produção. Já adiantamos que é um contexto difícil de acontecer, pois, em geral, mesmo greves comuns não são deflagradas quando não há quebra intensa de expectativas. É um contexto que, provavelmente, nunca tenha ocorrido no Brasil.

A empresa não passa por uma crise econômica (pelo menos não uma relevante), há faturamento suficiente e os salários não estão atrasados. No entanto, pela falta de acerto quanto a um item importante na negociação coletiva (ou outro problema de seriedade equivalente como, por exemplo, a demissão injusta de um líder sindical respeitado ou o atraso no pagamento de uma parcela de FGTS), os trabalhadores se comovem, organizam-se e deflagram greve. Passam os dias, mas, por quaisquer razões, o conflito não é solucionado; e, então, a assembleia decide não só que a greve é justa e deve continuar, mas que a pressão deve ser aumentada pela ocupação da empresa. O tempo passa novamente e não há acertos com o empregador. Então, finalmente, o coletivo operário delibera por ligar as máquinas e processar a matéria prima disponível, retomando a produção à revelia do empresário. A greve passiva, portanto, transforma-se em greve ativa. O empresário, em resposta, ajuíza ação possessória requerendo a desocupação forçada do estabelecimento. Eis o 
Contexto $1^{46}$.

O julgador deverá decidir pela procedência ou não do pedido patronal.

Apenas um dos três princípios suporta neste contexto o julgamento de improcedência - com a consequente manutenção da greve ativa. Como o conflito que originou a tomada operária não implicava ameaça ao trabalho e à fonte de renda dos trabalhadores (não houve inadimplemento de salários, nem demissões massivas, nem ameaça de fechamento), não se pode dizer que a manutenção da greve ativa implicará em satisfação do princípio do direito ao trabalho (art. $6^{\circ}$ ), pois, de fato, esse princípio estará satisfeito equivalentemente de uma maneira ou de outra. O mesmo vale para o princípio do valor social do trabalho (art. $1^{\circ}$, IV e 170, caput), pois, não havendo crise, não há o perigo de os trabalhadores sofrerem prejuízos de um risco que não assumiram nem controlaram. Por outro lado, podemos dizer que, se fosse considerado apenas o princípio da função social da propriedade dos bens de produção (art. 170, III), a decisão deveria ser pelo julgamento de improcedência e manutenção da greve ativa. Isso porque a gestão operária implica, em tese, em melhor cumprimento da função social dos bens de produção, dada a distribuição mais igualitária dos ganhos entre os produtores, o maior vínculo com a comunidade local, a ausência da lógica do lucro pelo lucro, entre outros. Essa satisfação, entretanto, pode ser considerada como "baixa", tendo em vista que não há garantia absoluta de que a gestão operária será, de fato, socialmente mais consequente, nem comprovação de quais seriam, realmente, esses benefícios. Pela lógica inversa, apenas esse princípio seria afetado pela decisão de desocupação. E afetado em "baixa" intensidade.

Por outro lado, tanto o princípio do direito de propriedade privada de bens de produção (art. 170, II) quanto o princípio do valor social da livre iniciativa (art. $1^{\circ}$, IV e 170, caput) seriam afetados pelo julgamento de improcedência da ação e consequente manutenção da greve ativa. E afetados em "alta" intensidade. O

\footnotetext{
${ }^{46}$ Devemos repetir que esse contexto não é, de maneira alguma, provável de acontecer. A atitude hipotética do coletivo operário afronta demasiadamente valores muito arraigados. É provável que, entre todas as greves ativas que já tenham ocorrido desde a consolidação do capitalismo, no século XVIII, pouquíssimas tenham emergido num contexto como esse. Entretanto, a análise deve ser feita por dois motivos: a) para responder-se à questão da legalidade da greve ativa no contexto que é regra geral; b) porque, de qualquer modo, existe a possibilidade, ainda que mínima, de uma greve assim acontecer, ainda mais diante de um possível contexto futuro de empolgação geral quanto à tomada operária de empresas.
} 
primeiro, porque o empresário estava usando plenamente os bens de produção, aplicando-os numa atividade econômica lícita; e, além disso, não praticou nenhum ato inconsequente ou violador no manejo dos mesmos, agindo dentro no esperado pela ordem jurídica de um controlador capitalista de bens de produção. A manutenção da greve ativa, portanto, afeta seu direito de propriedade em "alto" grau. O segundo, porque manter a gestão operária implicaria em desvalorizar intensamente o risco assumido e o investimento realizado pelo empresário na iniciativa do negócio, tendo em vista que ele nada fez que desabonasse essa iniciativa, não tendo demonstrado desídia na condução do empreendimento. Inversamente, ambos os princípios seriam satisfeitos em alto grau pela decisão de desocupação.

Assim, em síntese, a manutenção da greve ativa implicaria em uma alta afetação dos princípios favoráveis ao empresário e numa baixa satisfação do princípio favorável ao coletivo operário.

Avaliados esses pesos, concluímos que, diante do Contexto 1 (greve ativa realizada em reação a atos empresariais levemente violadores das responsabilidade social do controlador de bens de produção), nossa ordem jurídico-constitucional em vigor manda que a decisão seja pela desocupação e fim da greve ativa. Ela, portanto, é ilícita. Isso porque, nesse contexto, a alta afetação dos princípios constitucionais do direito de propriedade e do valor social da livre iniciativa causada pela greve ativa pesa mais que a baixa satisfação do princípio da função social da propriedade garantida por ela. $\mathrm{Ou}$, em outras palavras, os princípios do direito de propriedade e do valor social da livre iniciativa têm mais peso que o princípio da função social da propriedade sob essas condições concretas ${ }^{47}$.

\section{Contexto 2}

O segundo contexto é oposto ao primeiro. Consiste na deflagração de greve ativa em reação a uma situação de crise aguda acompanhada de ações socialmente inconsequentes por parte do empresário, que podemos identificar como atos de máfé empresarial. Esses atos podem ser definidos como aqueles que implicam numa violação grave às responsabilidades sociais estabelecidas pela ordem jurídica para o controlador de bens de produção. É o contexto em que emergiram quase todos os

\footnotetext{
${ }^{47}$ Podemos, ainda, usar a construção preferida por Alexy: os princípios do direito de propriedade e do valor social da livre iniciativa têm precedência em face do princípio da função social da propriedade sob essas condições (2006, p. 99).
} 
casos de ERT existentes no Brasil e Argentina (e suas respectivas ocupações ativas, quando foi o caso).

A empresa passa por uma crise econômica grave e há atraso de salários, ameaça de demissões massivas ou de fechamento. E o empresário capitalista praticou ou ameaça praticar atos socialmente inconsequentes ou egoístas, visando preservar sua própria riqueza sem se preocupar com as sequelas que tais ações trarão para a coletividade. São os atos que já classificamos como atos empresariais gravemente ilegais ou antissociais. Atos gravemente ilegais como, por exemplo, retirada clandestina de maquinário para fraudar credores, sonegação de tributos, inadimplemento grave de direitos trabalhistas, atentados graves à saúde ou à segurança dos trabalhadores, crimes falimentares (Lei n. 11.101/05), crimes ambientais (Lei n. 9.608/98), crimes contra a propriedade intelectual (Lei n. 9.279/96) e outros crimes empresariais. E atos gravemente antissociais, que são aqueles que refletem um posicionamento egoísta do empresário em prejuízo de interesses coletivos, apesar de não violarem diretamente uma lei; como, por exemplo, o fechamento de uma planta lucrativa para abertura de outra em condições piores para a sociedade (que explora trabalho precário, por exemplo ${ }^{48}$ ), ou a nomeação de sócios "laranjas" 49 . Diante dessa situação e desses atos, o coletivo operário organizase para lutar por sua sobrevivência e seus direitos e, a certa altura, inicia uma greve

\footnotetext{
${ }^{48}$ Sobre esse ato empresarial antissocial, é esclarecedora a narração dos trabalhadores do caso recente da New Era Windows, nos EUA, que já citamos em outro momento: "Em 2008, depois de muitas décadas de operação, a Republic Windows and Doors foi à falência e fechou. O que era estranho, pois o negócio de janelas parecia lucrativo. Ao mesmo tempo, negócios da família proprietária abriram novas fábricas em Chicago, contratando trabalhadores por meio de agências de trabalho temporário. Eles também estavam sendo investigados pelas autoridades por irregularidades na falência e foram processados por bancos por dívidas pendentes. Parecia que a razão para os trabalhadores perderem seus empregos não era que não estavam realizando um trabalho lucrativo" (NEW ERA WINDOWS COOPERATIVE, 2013). Tradução livre de: "In 2008, after many decades of operation, Republic Windows and Doors went bankrupt and was shut down. This seemed odd as the windows business appeared profitable. Meanwhile, members of the family business opened new windows factories in Chicago, hiring workers through temp agencies. They were also investigated by authorities over irregularities in their bankruptcy and were sued by banks over outstanding debts. It seemed the reason workers were losing their jobs might not be because they weren't doing profitable work".

${ }^{49}$ Importa esclarecer que temos ciência de que a prática desses atos por empresários capitalistas é recorrente. Faz parte da cultura empresarial capitalista agir para aumentar ou proteger a própria riqueza, principalmente em momentos de crise, sem dar importância às consequências. E isso, até mesmo, é muito pouco questionado. Recordamos aqui um "ditado empresarial": "Quando há sangue nas ruas, compre propriedades". Recordamos, também, a fala de um empresário euamericano durante a Guerra do Iraque, registrada no documentário Fahrenheit 11/9, de Michael Moore: "O Iraque é atualmente o melhor lugar para investir". Entretanto, é certo que os textos legais e o discurso oficial da ordem jurídica os condenam. E isso se torna mais relevante à medida que uma organização empresarial operária se coloca como uma alternativa à capitalista, o que possivelmente esteja ocorrendo neste início de século.
} 
ativa. E o patrão ajuíza ação possessória requerendo a desocupação forçada do estabelecimento. Eis o Contexto 2.

O julgador, como no Contexto 1, deve decidir pela procedência ou improcedência do pedido.

Nesse contexto, a manutenção da greve ativa (e do controle operário) é sustentada pelos três princípios. E com "alto" grau de satisfação. Satisfação do princípio do direito ao trabalho (art. $6^{\circ}$ ), porque a greve ativa e a continuação da produção são meios imediatos de garantir a inadiável necessidade de trabalho e renda dos trabalhadores, que está seriamente ameaçada pelo contexto de crise e pelos atos de má-fé empresarial. Do princípio do valor social do trabalho (art. $1^{\text {o }}$, IV e 170, caput), porque a greve ativa é uma via de evitar que os trabalhadores arquem com prejuízos que não assumiram, valorizando sua posição de não controladores da produção mal gerida; valorização que merece ser ainda maior em razão dos atos de má-fé do empresário, que mostram desídia pela alta responsabilidade de sua posição e tentativa de passar a terceiros riscos que assumiu para si. E, evidentemente, da função social da propriedade dos bens de produção (art. 170, III); em primeiro lugar porque a greve ativa é o meio de continuação da produção como fonte de trabalho e renda, de movimentação da economia (mais saudável que a anterior, dada a má-fé empresarial), e de fabricação de produtos úteis ou necessários, resultados sociais da produção que estavam seriamente ameaçados nas mãos do capitalista; em segundo, porque é o um meio eficaz (talvez o único) de evitar o "esvaziamento" da planta ou outros atos socialmente lesivos pelo empresário inconsequente, práticas que são comumente apontadas pelos trabalhadores como motivadoras de ocupações $^{50}$. Isso sem mencionar a chance, incerta mas existente, de a gestão operária ser socialmente mais benéfica que a capitalista. Pelas mesmas razões, a ordem de desocupação, com retorno do controle do estabelecimento às mãos do empresário, afetaria muito intensamente esses três princípios.

\footnotetext{
50 Já mencionamos que os trabalhadores de $12 \%$ das ERTs brasileiras indicam a prática de "esvaziamento" como causadora da recuperação (HENRIQUES et al., 2013, p. 46). Vale citar, ainda, a observação de Pinho Pedreira de que "em certos conflitos a ocupação tem permitido aos grevistas tomar conhecimento de documentos reveladores de uma realidade econômica ou jurídica desconhecida por vezes mesmo dos representantes do pessoal" (1993, p. 94). Nessas situações, os trabalhadores descobrem informações importantes para a coletividade e que eram mantidas em segredo pelo empresário, como, por exemplo, que a empresa estava com mais dívidas do que informava oficialmente, que não recolhia contribuições previdenciárias, que planejava demissões massivas ou fechar um setor inteiro. São exemplos de circunstâncias típicas de empresas controladas por adeptos à "doutrina” da má-fé capitalista.
} 
Quanto aos dois princípios opostos, é certo que a manutenção da ocupação operária os afetará. Essa afetação, entretanto, será de "baixa" importância. Para o princípio do direito de propriedade privada de bens de produção (art. 170, II), porque esses bens, nas mãos do empresário, estavam sendo mal utilizados, pois aplicados de modo mal organizado e não lucrativo, numa atividade gerida de modo inconsequente e violador. Circunstâncias que reduzem a importância da proteção desse direito pela ordem jurídica e, por isso, militam a favor da manutenção da greve ativa. Para o princípio do valor social da livre iniciativa (art. $1^{\circ}$, IV e 170, caput), porque ordenar a desocupação significaria, com relação a esse princípio, tentar valorizar algo que já havia sido rigorosamente desvalorizado pelo próprio empresário, que é a audácia da iniciativa econômica e da assunção de riscos que ela representa; o valor social dessa postura empreendedora ficou totalmente maculado pelos atos de desídia do empresário para com a alta responsabilidade de sua posição, atos que tentavam transferir os prejuízos da atividade para terceiros mais vulneráveis, como os trabalhadores; por isso, garantir essa valorização seria de pouquíssima importância. O julgamento de improcedência da ação e consequente manutenção da greve ativa, portanto, importaria numa afetação de baixa importância desses princípios. E, pelas mesmas razões, a desocupação significaria uma satisfação pouco importante desses princípios.

Em síntese, a manutenção da greve ativa implicaria em uma alta satisfação dos três princípios favoráveis aos trabalhadores e numa baixa satisfação dos dois princípios favoráveis ao empresário.

Feito o sopesamento, concluímos que, diante do Contexto 2 (greve ativa realizada em reação à crise intensa acompanhada de atos de má-fé empresarial), nossa ordem jurídico-constitucional em vigor determina que se decida pela manutenção da greve ativa. Ela, portanto, é lícita. Isso porque, nesse contexto, a alta satisfação dos princípios constitucionais do direito ao trabalho, do valor social do trabalho e da função social da propriedade garantida pela greve ativa pesa mais que a baixa afetação dos princípios do direito de propriedade e do valor social da livre iniciativa provocada por ela. Ou, em outras palavras, os princípios do direito ao trabalho, do valor social do trabalho e da função social da propriedade têm mais peso que os do direito de propriedade e do valor social da livre iniciativa sob essas condições concretas. 


\section{Contexto 3}

O terceiro contex to se situa, podemos dizer, em um lugar intermediário entre o primeiro e o segundo. Sua análise servirá para estabelecermos as condições limite de a licitude da greve ativa. Ele consiste na deflagração de greve ativa em reação a uma situação de crise aguda causada pela má gestão da atividade empresarial. É um fenômeno menos frequente que o do Contexto 2, mas ocorre. A pesquisa das ERTs brasileiras revelou que em $19 \%$ das recuperações se aponta como causa do início do processo, entre outras, a "má gestão dos antigos donos ou conflito entre os donos que levaram à má administração do negócio" (HENRIQUES et al., 2013, p. 46).

Nesse contexto, como no segundo, a empresa passa por uma crise econômica grave e há atraso de salários, ameaça de demissões massivas ou de fechamento. A causa principal dessa crise, entretanto, não são atos de má-fé empresarial, nem a influência inescapável de uma crise econômica generalizada, mas a má qualidade da gestão realizada pelo empresário ou grupo empresarial. Isso ocorre, por exemplo, quando os administradores passam a conflitar entre si por motivos pessoais, descuidando do negócio e das responsabilidades da posição e, com isso, gerando a crise. Nesse contexto a gestão patronal, portanto, não praticou, nem ameaça praticar, atos que podem ser classificados como de má-fé empresarial. Não violou a lei nem realizou atos socialmente inconsequentes visando preservar sua própria riqueza à custa de terceiros. A crise é fruto, principalmente, da falta de habilidade, prudência ou zelo da gestão do empresário ${ }^{51}$. Seriam indícios dessa má gestão, por exemplo, a ausência de uma racionalidade administrativa mínima, a ocorrência constante de atrasos no pagamento de dívidas, a ausência de um quadro de divisão clara de funções entre os colaboradores etc. Apesar de não haver má-fé por parte do ocupante da gestão, é fato que ele gerou, de qualquer maneira, a situação crítica, e ela ameaça gravemente a continuidade da produção e a fonte de renda dos trabalhadores. Por isso, em sua situação de desespero, o coletivo operário organiza-se para lutar por sua sobrevivência e seus direitos e, a certa altura, foi além e tomou a difícil iniciativa de começar uma greve ativa. Em resposta, o empresário ajuizou ação

\footnotetext{
${ }^{51}$ Para usar a dualidade clássica da teoria da responsabilidade criminal, poderíamos dizer que, neste Contexto 3, o empresário agiu com culpa na causação da crise (imperícia, imprudência ou negligência). Enquanto, no Contexto 2, agiu com dolo (os atos antissociais foram realizados intencionalmente).
} 
possessória requerendo a retomada do controle do estabelecimento. Temos o Contexto 3.

O julgador da ação deverá decidir por ordenar a desocupação ou não.

A manutenção da greve ativa pelo estado-juiz implicaria em afetação aos dois princípios favoráveis ao empresário. E uma afetação, neste caso, de importância "moderada". No caso do princípio do direito de propriedade privada de bens de produção (art. 170, II) porque, em razão da gestão de má qualidade, esses bens estavam sendo mal aproveitados, pois aplicados irracionalmente e desorganizadamente; inclusive sob o ponto de vista puro do lucro. $\mathrm{O}$ aproveitamento débil do potencial produtivo, com a geração de crises e instabilidade nas relações econômicas internas e externas, é uma circunstância que reduz a importância da proteção da propriedade dos bens de produção pelo direito. Não tanto, é certo, quanto os atos de má-fé empresarial - deve-se levar em conta que não houve dolo por parte do gestor. Mas, com certeza, a importância de proteger esses bens de produção é inferior à importância de proteger bens de produção geridos com eficácia. Com relação ao princípio do valor social da livre iniciativa (art. $1^{\circ}$, IV e 170, caput), porque a iniciativa econômica de empreendedores incapazes, imprudentes ou negligentes com relação às responsabilidades decorrentes de sua posição não tem a mesma importância que a de empreendedores competentes. O princípio determina que a ordem jurídica valorize a livre iniciativa pelos benefícios sociais que traz (valor social da livre iniciativa); a iniciativa de um gestor insensato até tem seu valor como tentativa, ato de "coragem", mas não vale tanto quanto a iniciativa de um gestor hábil. Proteger a iniciativa de um mau gestor, portanto, tem importância moderada (até mesmo, baixa, talvez). Assim, a manutenção da greve ativa implicaria numa afetação de importância moderada desses princípios. E, consequentemente, a desocupação significaria uma satisfação deles de grau médio.

Sustentando o outro lado - a manutenção da greve ativa - estão os outros três princípios. E, no caso, essa medida implicaria numa satisfação de "alto" grau para dois deles, e de grau "moderado" para o outro. O princípio do direito ao trabalho $\left(\operatorname{art.~} 6^{\circ}\right.$ ) seria satisfeito em "alto" grau, porque, como no Contexto 2, a greve ativa e a continuação da produção são meios imediatos de garantir a inadiável necessidade de trabalho e renda dos trabalhadores, que, independentemente da má-fé 
ou boa-fé dos empresários, está seriamente ameaçada pelo contexto de crise. Também o princípio do valor social do trabalho (art. $1^{\circ}$, IV e 170, caput) seria satisfeito em "alto" grau, porque, como no Contexto 2, a greve ativa é uma via de evitar que os trabalhadores arquem com prejuízos que não assumiram, valorizando sua posição de não controladores da produção mal gerida; valorização cuja intensidade, do mesmo modo, é alta independentemente da boa-fé ou má-fé do empresário. É diferente, entretanto, a satisfação do princípio da função social da propriedade dos bens de produção (art. 170, III), que deve ser considerada de importância apenas "moderada". Isso porque, apesar de a má gestão do empresário prejudicar os efeitos sociais benéficos da produção (movimentação da economia, geração de trabalho e renda, fabricação de produtos úteis), a extensão desse prejuízo social é inferior à causada pelo gestor que pratica atos antissociais e ilegais. Por isso, a manutenção da greve ativa (com consequente afastamento do gestor capitalista) implicará numa satisfação desse princípio de importância apenas moderada. Pelas mesmas razões, a desocupação e o fim da greve ativa causariam uma afetação de alta importância para os princípios do direito ao trabalho e do valor social do trabalho, e de média importância para o princípio da função social da propriedade.

Considerando todo o sopesamento, temos que a manutenção da greve ativa implicaria numa alta satisfação de dois princípios favoráveis aos trabalhadores, numa satisfação moderada de um princípio também favorável, e numa satisfação moderada dos dois princípios favoráveis ao empresário.

Desse modo, pela análise das importâncias dos cinco princípios incidentes, concluímos que, diante do Contexto 3 (greve ativa realizada em reação a crise intensa gerada por má gestão da atividade), nossa ordem jurídico-constitucional em vigor determina que se decida pela manutenção da greve ativa. Ela, portanto, é lícita. Isso porque, nesse contexto, a alta satisfação dos princípios constitucionais do direito ao trabalho, do valor social do trabalho em conjunto com a satisfação moderada do princípio da função social da propriedade garantida pela greve ativa pesa mais que a afetação moderada dos princípios do direito de propriedade e do valor social da livre iniciativa provocada por ela. Em outras palavras, os princípios do direito ao trabalho, do valor social do trabalho e da função social da propriedade têm mais peso que os do direito de propriedade e do valor social da livre iniciativa 
sob essas condições concretas ${ }^{52}$.

Temos, assim, as conclusões dos três sopesamentos.

Conjugando-as, podemos construir a seguinte conclusão geral acerca da licitude da greve ativa: a greve ativa - ocupação operária do local de trabalho para produzir - é lícita, de acordo com nossa ordem jurídico-constitucional - em especial, os princípios do direito de propriedade, do valor social da livre iniciativa, do direito ao trabalho, do valor social do trabalho e da função social da propriedade - se for deflagrada como resposta a uma crise aguda na empresa, gerada por má gestão ou acompanhada de atos de má-fé empresarial (atos que implicam numa violação grave das responsabilidades sociais estabelecidas pela ordem jurídica para o controlador de bens de produção). Fora dessas condições, por outro lado, a greve ativa é ilícita ${ }^{53}$.

Assim, chegamos ao fim da investigação que nos propusemos a fazer. Nosso objetivo foi verificar o que emerge do confronto entre os mandamentos mais altos de nossa Constituição e a realidade desse fenômeno crescente na vida do sistema social capitalista, as greves ativas.

De todo o exposto, podemos concluir, em primeiro lugar, que a greve ativa - ou seja, a greve com ocupação para produzir - é modalidade de greve protegida pelo artigo $9^{\circ}$ da Constituição, diante de seu texto eclético, garantidor de toda ação coletiva e organizada de trabalhadores em reação ao trabalho subordinado.

Em segundo, que carece de legitimidade qualquer análise da licitude de uma greve ativa fundamentada na Lei n. 7.783/89, tendo em vista que seu complexo

\footnotetext{
52 Seria correto concluir que a emersão do fenômeno das recuperações operárias traz como consequência um aumento da responsabilidade social do empresário capitalista. Quanto mais acontecer de operários demonstrarem, perante a sociedade, que são capazes de autogerir uma empresa, mais a sociedade olhará para o empresário capitalista e o pressionará para mostrar que é capaz de gerir negócios de maneira socialmente consequente, principalmente na relação com seus próprios empregados.

${ }^{53}$ Importa dizer que essa conclusão vai ao encontro da que construímos acima (tópico 3.1.1) a partir do princípio da função social da propriedade, que foi a seguinte: "O princípio do artigo 170, III, da Constituição (função social da propriedade) impõe que sempre que um empresário em crise houver praticado atos ilegais ou antissociais (que prejudiquem interesses coletivos em favorecimento de interesses egoístas), a proteção jurídica de sua propriedade ficará sujeita a desaparecer, o que efetivamente se concretizará se os trabalhadores desafiarem seu controle efetivo da atividade produtiva e sua legitimidade manifestando a intenção de continuar a empresa coletivamente. Em outras palavras, a prática de atos empresariais ilegais ou antissociais abre, para o coletivo operário, o caminho para assunção juridicamente legítima da atividade". Na verdade, a análise que finalizamos agora é mais completa que a primeira, pois considera os outros princípios constitucionais importantes.
} 
normativo desconsidera absolutamente a realidade desse fenômeno social e as questões jurídicas e sociais que dele emergem. Que, portanto, o analista deve pautar sua análise em outras fontes normativas.

Em terceiro, que tal modalidade de greve, se analisada a partir de um confronto com os princípios da Constituição à luz da Teoria dos Direitos Fundamentais, deve ser qualificada como lícita, se for deflagrada como resposta a uma crise aguda na empresa, gerada por má gestão ou acompanhada de atos de má-fé empresarial (atos que implicam numa violação grave das responsabilidades sociais estabelecidas pela ordem jurídica para o controlador de bens de produção). Isso porque, nessas condições, a importância da satisfação dos princípios constitucionais favorecidos (direito ao trabalho, valor social do trabalho e função social da propriedade) é maior que a importância da afetação dos princípios constitucionais desfavorecidos (direito de propriedade e valor social da livre iniciativa). 


\section{CAMINHOS LATINO-AMERICANOS: AS CONQUISTAS NA ARGENTINA E NO URUGUAI}

Já mencionamos que o fenômeno das recuperações operárias tem presença marcante não só no Brasil, mas também em outros países latino-americanos - de modo que seu centro avançado mundial, ao que tudo indica, está na Argentina.

Uma das consequências naturais dessa presença é a emergência de normas jurídicas que visam regular o fenômeno. Nos casos da Argentina e do Uruguai, em especial, foram editados, na última década, alguns diplomas normativos bastante favoráveis aos recuperadores, frutos de duros processos de militância coletiva.

É de grande valia conhecer essas conquistas, pois podem servir de base para a construção de soluções favoráveis no Brasil.

Este capítulo tem por objetivo fazer uma exposição sumária dos dois principais exemplos de diplomas normativos elaborados especificamente para as recuperações operárias. Na Argentina, a Ley $n^{o} 26.684$ de 29/06/2011, que alterou largamente a Lei de Concursos e Quiebras para reconhecer sistematicamente a possibilidade de uma cooperativa formada por ex-empregados assumir a continuação da empresa em crise. E, no Uruguai, o Decreto $n^{o}$ 165/2006, norma inédita destinada a regular a ocupação ativa de empresas por trabalhadores.

\subsection{O destaque argentino: reconhecimento sistemático na lei de falências}

Em junho de 2011, os trabalhadores argentinos lograram a aprovação da Ley $n^{o}$ 26.684 de 29/06/2011, que alternou a Ley de Concursos e Quiebras (24.522/1995) para tratar "da participação dos trabalhadores na recuperação dos meios de produção 
e da fonte de trabalho em caso de processo concursal ou de falência" ${ }^{54}$. Diploma que é, com certeza, a maior conquista legislativa alcançada pelos recuperadores do país.

Resultado de uma longa batalha por reconhecimento jurídico, esse diploma tem suas origens no Proyecto 6.971.D-01, apresentado ao legislativo nacional em 2001 (ano de explosão de tomadas operárias), pelo deputado Hector Polino (ALONSO, 2012).

$\mathrm{Na}$ mensagem que acompanhou o projeto, quando do encaminhamento para sanção do poder executivo, o Congresso Nacional colocou como objetivo da lei alteradora o seguinte:

favorecer a continuidade da exploração das empresas que se encontram em situação de crise por parte de seus trabalhadores que se organizam em cooperativas, para permitir, dessa maneira, a conservação das fontes de produção e trabalho; priorizar a subsistência das empresas, para assegurar a continuidade de sua produção e a geração de empregos, dando a possibilidade para as cooperativas de trabalho conformadas pelos mesmos operários que eram empregados das empresas e/ou fábricas falidas. Entendendose que, com a manutenção da exploração, se conservam ativos da empresa muito importantes como a marca, o fundo de comércio e a força laboral. Espera-se que, mediante a normativa proposta, muitos dos trabalhadores que se deparem com a perda de sua fonte de emprego poderão decidir permanecer em seus postos de trabalho (ALONSO, 2012) ${ }^{55}$.

A norma representou, como destaca Francisco Junyent Bas, professor da Universidad Nacional de Córdoba, uma verdadeira reformulação das relações laborais, tanto no concurso preventivo (que corresponde à recuperação judicial da Lei n. 11.101/2005 brasileira) quanto na falência.

Destacaremos as cinco modificações mais importantes que advieram com o diploma, segundo o apontamento da jurista argentina Iliana Vilchez (2013, p. 114-7).

\footnotetext{
${ }^{54}$ Tradução livre do texto oficial descritivo do projeto: "Proyecto de ley modificando la Ley No 24.522 - Concursos y Quiebras, respecto de la participación de los trabajadores en la recuperación de los medios de producción y la fuente laboral en caso de proceso concursal o quiebra".

${ }^{55}$ Tradução livre de: "el objetivo del proyecto es 'favorecer la continuidad de la explotación de las empresas que se encuentren en situaciones de crisis, por parte de los trabajadores de las mismas, que se organicen en cooperativas para permitir de esa manera, la conservación de la fuentes de producción y trabajo; priorizar la subsistencia de las empresas, para asegurar la continuidad de su producción y la generación de empleos, dando la posibilidad a las cooperativas de trabajo de existir conformadas por los mismos obreros que fueron dependientes de la empresas y/o fábricas quebradas. Ello en el entendimiento de que con el mantenimiento de la explotación, se conservan activos de la empresa muy importantes como ser, la marca, el fondo de comercio y la fuerza laboral. Se estima que mediante la normativa propuesta frente a la pérdida de su fuente de empleo, muchos de los trabajadores podrán decidir permanecer en sus puestos laborales"”.
} 
Duas delas são referentes ao procedimento concursal e três ao procedimento falimentar.

A primeira consiste na possibilidade expressa, alocada nos artigos 48 e 48 bis da Lei 24.522/1995, de uma cooperativa de trabalho conformada por empregados apresentar acordos preventivos (que corresponderiam aos nossos planos de recuperação) para adquirir a empresa no processo concursal. Usando, inclusive, seus créditos trabalhistas pendentes. Eis o texto legal, no original, com grifos nossos:

ARTÍCULO 48. Supuestos especiales. En el caso de sociedades de
responsabilidad limitada, sociedades por acciones, sociedades
cooperativas, y aquellas sociedades en que el Estado nacional,
provincial o municipal sea parte, con exclusión de las personas
reguladas por las leyes 20.091, 20.321, 24.241 y las excluidas por
leyes especiales, vencido el período de exclusividad sin que el
deudor hubiera obtenido las conformidades previstas para el
acuerdo preventivo, no se declarará la quiebra, sino que: 1) Apertura de un registro. Dentro de los dos (2) días el juez dispondrá la apertura de un registro en el expediente para que dentro del plazo de cinco (5) días se inscriban los acreedores, la cooperativa de trabajo conformada por trabajadores de la misma empresa —incluida la cooperativa en formación- y otros terceros interesados en la adquisición de las acciones o cuotas representativas del capital social de la concursada, a efectos de formular propuesta de acuerdo preventivo. Al disponer la apertura del registro el juez determinará un importe para afrontar el pago de los edictos. Al inscribirse en el registro, dicho importe deberá ser depositado por los interesados en formular propuestas de acuerdo

\section{$[\ldots]$}

Artículo 48 bis. En caso que, conforme el inciso 1 del artículo anterior, se inscriba la cooperativa de trabajo -incluida la cooperativa en formación-, el juez ordenará al síndico que practique liquidación de todos los créditos que corresponderían a los trabajadores inscriptos por las indemnizaciones previstas en los artículos 232, 233 y 245 del Régimen de Contrato de Trabajo aprobado por ley 20.744, los estatutos especiales, convenios colectivos o la que hayan acordado las partes. Los créditos así calculados podrán hacerse valer para intervenir en el procedimiento previsto en el artículo anterior.

Homologado el acuerdo correspondiente, se producirá la disolución del contrato de trabajo de los trabajadores inscriptos y los créditos laborales se transferirán a favor de la cooperativa de trabajo convirtiéndose en cuotas de capital social de la misma. El juez fijará el plazo para la inscripción definitiva de la cooperativa bajo apercibimiento de no proceder a la homologación. La cooperativa asumirá todas las obligaciones que surjan de las conformidades presentadas. 
El Banco de la Nación Argentina y la Administración Federal de Ingresos Públicos, cuando fueren acreedores de la concursada, deberán otorgar las respectivas conformidades a las cooperativas, y las facilidades de refinanciación de deudas en las condiciones más favorables vigentes en sus respectivas carteras.

Queda exceptuada la cooperativa de trabajadores de efectuar el depósito del veinticinco por ciento $(25 \%)$ del valor de la oferta prevista en el punto i), inciso 7 del artículo $48 \mathrm{y}$, por el plazo que determine la autoridad de aplicación de la ley 20.337, del depósito del cinco por ciento (5\%) del capital suscripto previsto en el artículo 90 de la ley 20.337. En el trámite de constitución de la cooperativa la autoridad de aplicación encargada de su inscripción acordará primera prioridad al trámite de la misma debiéndose concluir dentro de los diez (10) días hábiles.

A segunda modificação, também relacionada ao procedimento concursal, consiste na conservação da exigibilidade dos créditos trabalhistas após a abertura do concurso preventivo, criando-se uma exceção exclusiva. A exceção foi introduzida no artigo 19:

\begin{abstract}
ARTICULO 19. Intereses. La presentación del concurso produce la suspensión de los intereses que devengue todo crédito de causa o título anterior a ella, que no esté garantizado con prenda o hipoteca. Los intereses de los créditos así garantizados, posteriores a la presentación, sólo pueden ser reclamados sobre las cantidades provenientes de los bienes afectado a la hipoteca o a la prenda.
\end{abstract}

Deudas no dinerarias. Las deudas no dinerarias son convertidas, a todos los fines del concurso, a su valor en moneda de curso legal, al día de la presentación o al del vencimiento, si fuere anterior, a opción del acreedor. Las deudas en moneda extranjera se calculan en moneda de curso legal, a la fecha de la presentación del informe del síndico previsto en el artículo 35, al solo efecto del cómputo del pasivo y de las mayorías.

Quedan excluidos de la disposición precedente los créditos laborales correspondientes a la falta de pago de salarios y toda indemnización derivada de la relación laboral.

A terceira modificação, esta referente ao procedimento de falência, é a previsão de continuação imediata da atividade no caso de decretação de falência, assentada nos artigos 189 e 191 bis. Essa continuação será feita pelo síndico (que corresponde ao administrador judicial da lei brasileira) ou, caso ele não o faça, por uma cooperativa de trabalho - constituída ou em formação - composta por pelo menos 2/3 dos empregados ativos ou credores trabalhistas. Vejam-se os dispositivos:

ARTíCULO 189. Continuación inmediata. El síndico puede continuar de inmediato con la explotación de la empresa o alguno de sus establecimientos, si de la interrupción pudiera resultar con evidencia un daño grave al interés de los acreedores y 
a la conservación del patrimonio, si se interrumpiera un ciclo de producción que puede concluirse o entiende que el emprendimiento resulta económicamente viable. También la conservación de la fuente de trabajo habilita la continuación inmediata de la explotación de la empresa o de alguno de sus establecimientos, si las dos terceras partes del personal en actividad o de los acreedores laborales, organizados en cooperativa, incluso en formación, la soliciten al síndico o al juez, si aquél todavía no se hubiera hecho cargo, a partir de la sentencia de quiebra y hasta cinco (5) días luego de la última publicación de edictos en el diario oficial que corresponda a la jurisdicción del establecimiento. El síndico debe ponerlo en conocimiento del juez dentro de las veinticuatro (24) horas. El juez puede adoptar las medidas que estime pertinentes, incluso la cesación de la explotación, con reserva de lo expuesto en los párrafos siguientes. Para el caso que la solicitud a que refiere el segundo párrafo el presente, sea una cooperativa en formación, la misma deberá regularizar su situación en un plazo de cuarenta (40) días, plazo que podría extenderse si existiesen razones acreditadas de origen ajeno a su esfera de responsabilidad que impidan tal cometido.

Artículo 191 bis. En toda quiebra que se haya dispuesto la continuidad de la explotación de la empresa o de alguno de sus establecimientos por parte de las dos terceras partes del personal en actividad o de los acreedores laborales, organizados en cooperativas, incluso en formación, el Estado deberá brindarle la asistencia técnica necesaria para seguir adelante con el giro de los negocios.

Em quarto lugar, temos a importante previsão, presente no artigo 203, de aquisição da massa falida pelos trabalhadores reunidos em cooperativa de trabalho, com garantia da compensação dos créditos trabalhistas na transação, calculados da forma que resultar mais favorável aos operários. Eis o texto do dispositivo:

Artículo 203 bis. Los trabajadores reunidos en cooperativa de trabajo están habilitados para solicitar la adquisición de conformidad con el artículo 205, incisos 1) y 2) y podrán hacer valer en ese procedimiento la compensación con los créditos que le asisten a los trabajadores de la fallida, de conformidad a los artículos 241, inciso 2) y 246 , inciso 1) de la ley concursal, no siendo aplicable en este caso la prohibición del artículo 211. El monto de las indemnizaciones será calculado, a los fines de la compensación, de conformidad con el artículo 245 de la ley 20.744 (t.o. 1976), los estatutos especiales, convenios colectivos o contratos individuales, según el que resultare más favorable a los trabajadores. A tal efecto, podrán utilizarse total o parcialmente los créditos laborales de los que resulten titulares trabajadores que voluntariamente los cedan a la cooperativa. La cesión se materializará en audiencia a celebrarse ante el juez de la quiebra con intervención de la asociación sindical legitimada. El plazo del pago del precio podrá estipularse al momento de efectuarse la venta. 
Por último, enfim, temos a possibilidade de suspensão no procedimento de falência, sob certas condições, de execução ou penhora de bens necessários para a exploração da atividade, mesmo por parte de credores com garantia real. A suspensão foi colocada no artigo 195 da lei falimentar:

ARTICULO 195.- Hipoteca y prenda en la continuación de empresa. En caso de continuación de la empresa, los acreedores hipotecarios o prendarios no pueden utilizar el derecho a que se refieren los artículos 126, segunda parte, y 209, sobre los bienes necesarios para la explotación, en los siguientes casos:

1) Cuando los créditos no se hallen vencidos a la fecha de la declaración y el síndico satisfaga las obligaciones posteriores en tiempo debido;

2) Cuando los créditos se hallen vencidos a la fecha de la declaración, mientras no cuenten con resolución firme que acredite su calidad de acreedor hipotecario o prendario;

3) Cuando exista conformidad del acreedor hipotecario o prendario para la suspensión de la ejecución.

Son nulos los pactos contrarios a las disposiciones de los incisos 1) y 2).

Por decisión fundada y a pedido de la cooperativa de trabajadores, el juez de la quiebra podrá suspender las ejecuciones hipotecarias y/o prendarias por un plazo de hasta dos (2) años.

Essas, portanto, são as cinco principais modificações da lei falimentar argentina introduzidas pela Ley $\mathrm{n}^{\circ}$ 26.684/2011, primeiro diploma legislativo da história que transformou em direito positivo sistematizado a recuperação operária de empresas.

Trata-se de um avanço estupendo, tendo em vista que, como as recuperações acontecem após a empresa entrar em crise, quase sempre os processos judiciais falimentares se fazem presentes e obrigam os trabalhadores a lidar com eles.

No Brasil, por exemplo, esses processos estiveram ou estão presentes, com relação à gestão patronal, em 74\% das empresas recuperadas (HENRIQUES et al., 2013, p. 67). O reconhecimento expresso e sistemático da possibilidade de recuperação impede o que ocorreu, por exemplo, no importante caso brasileiro da Usina Catende/Cooperativa Harmonia, em que o administrador judicial falimentar foi nomeado para retirar a gestão das mãos dos trabalhadores (HENRIQUES et al., 2013, p. 66). 
De fato, como foi observado pelos mapeadores brasileiros de empresas recuperadas, "uma parcela considerável das ERTs vivenciou o processo de falência da empresa originária e, por esse motivo, a lei de falências tem vital importância para a compreensão do fenômeno de recuperação de empresas por trabalhadores" (HENRIQUES et al., 2013, p. 68).

Assim, essa importante conquista legislativa dos recuperadores da Argentina, a Ley n. 26.684/2011, é, por certo, o maior exemplo atual de como o fenômeno da recuperação operária de empresas pode e deve ser objeto de regulação jurídica específica.

\subsection{A oficialização da greve de ocupação no Uruguai}

Outro importante exemplo de positivação jurídica derivada do fenômeno da recuperação operária de empresas é o Decreto n. 165 de 30/052006, editado pelo poder executivo nacional do nosso outro vizinho do sul, o Uruguai.

O decreto, como aponta o juslaboralista da Universidad de la República Oscar Ermida Uriarte, "contêm duas partes bem diferenciadas. Por um lado se sistematizam meios de solução de conflitos coletivos já existentes em normas dispersas e, por outro, se trata da ocupação dos lugares de trabalho" $(2006, \text { p. } 7)^{56}$.

O diploma não tem, é certo, o mesmo peso que a Ley n. 26684 argentina. Entre outras razões, porque não tem a mesma complexidade, e porque se trata justamente de um decreto, ato do poder executivo, e não de uma lei (circunstância, a propósito, que faz com que vários agentes jurídicos o apontem como inconstitucional).

\footnotetext{
${ }^{56}$ Tradução livre de: "Este decreto, denominado de prevención y solución de conflictos colectivos y de reglamentación de las ocupaciones, contiene dos partes bien diferenciadas. Por un lado se sistematizan medios de solución de conflictos colectivos ya existentes en normas dispersas y por otro, se trata de la ocupación de los lugares de trabajo".
} 
Entretanto, ele tem vigência e, mais importante, é a única regulamentação estatal específica existente (não só no Uruguai, como no restante do mundo).

Quanto ao seu teor, expõe Uriarte:

sobre esse segundo ponto [a ocupação dos lugares de trabalho], de uma parte declara, em conformidade com a doutrina e jurisprudência nacionais, que a ocupação é uma manifestação da greve; mas, de outra, autoriza o Poder Executivo a dispor o desalojamento dos ocupantes, já não por iniciativa do empregador, como no velho decreto derrogado, mas quando a continuidade da medida ponha em grave risco a vida, segurança ou saúde da população ou afetar seriamente a ordem pública $(2006, \text { p. } 7)^{57}$.

Como se vê, a norma reconhece expressamente a ocupação como forma atípica de exercício do direito de greve. Indo ao encontro, portanto, das conclusões que tecemos no capítulo três. Um reconhecimento favorável aos trabalhadores, certamente, mas que, no país, como apontam Brignoni e Rooca, já estava reconhecido pela doutrina nacional, "que postula um conceito amplo de greve, que não exclui todas as suas formas ou modalidades atípicas" $(2012, \text { p. } 4)^{58}$.

Importa atentar para o fato de que o decreto determina que, a princípio, a ocupação é lícita caso permaneça após "fracassados os mecanismos autônomos e heterônomos de solução de conflitos" (BRIGNONI; ROOCA, 2012, p. 4). Isso porque, nesse caso, só poderá ser encerrada forçosamente quando estiverem presentes algumas das ameaças ao interesse público indicadas por Uriarte. Do contrário, deverá permanecer. Portanto, neste sentido, também, o decreto se coaduna com nossas conclusões do terceiro capítulo.

Observe-se, entretanto, que não é possível afirmar que a norma agradou absolutamente os recuperadores uruguaios. Na verdade, como pondera Uriarte,

Gregos e troianos impugnaram esta iniciativa. Os empregadores porque se opunham a uma consagração estatal expressa da legitimidade da ocupação, que na verdade já estava consolidada, ainda que a nível doutrinal e jurisprudencial, sem o respaldo de uma norma regulamentadora. Os trabalhadores porque a consideraram uma regulamentação limitativa do direito de greve

\footnotetext{
${ }^{57}$ Tradução livre de: "Sobre este segundo punto, de una parte, declara, de conformidad con la doctrina y jurisprudencia nacionales, que la ocupación es una manifestación de la huelga; pero de otra, autoriza al Poder Ejecutivo a disponer el desalojo de los ocupantes, ya no a iniciativa del empleador, como en el viejo decreto derogado, sino cuando la continuidad de la medida ponga en grave riesgo la vida, seguridad o salud de la población o afectare seriamente el orden público".

58 Tradução livre de: "siguiendo los lineamientos de la doctrina nacional que postula un concepto amplio de la huelga, que no excluye todas las formas o modalidades atípicas de huelga”.
} 
que só seria procedente por lei e não por decreto $(2006, \text { p. } 7)^{59}$.

Mas, a nosso ver, essa circunstância não deve ser vista como problemática. Na verdade, seria o esperado para a regulamentação de um tema ao mesmo tempo tão presente na realidade atual e tão conflituoso.

Como já afirmamos, o fenômeno da recuperação necessita, para se desenvolver, da criação de leis e realização de políticas públicas que considerem as suas especificidades. Por isso,

[...] a conquista de um marco legal e, em geral, a promoção de políticas públicas que considerem a especificidade das ERTs, que sejam menos adversas em relação às iniciativas de recuperação de empresas, que permitam o acesso a crédito governamental, são vistas por uma parcela significativa das empresas pesquisadas como uma condição para reverter o que consideram um posicionamento contrário do Estado em relação a elas (HENRIQUES et al., 2013, p. 210).

Para o desenvolvimento dessa tarefa, é fundamental conhecer e compreender as conquistas legislativas e a evolução jurisprudencial e jurídicocientífica dos nossos vizinhos latino-americanos.

\footnotetext{
59 Tradução livre de: "Tirios y troyanos impugnaron esta iniciativa. Los empleadores porque se oponían a una consagración estatal expresa de la legitimidad de la ocupación, la que en verdad ya estaba consolidada aunque a nivel doctrinal y jurisprudencial, sin el respaldo de una norma reglamentaria. Los trabajadores porque la consideraron una reglamentación limitativa del derecho de huelga que solo sería procedente por ley y no por decreto".
} 


\title{
5 UM ENSAIO: GESTÃo OPERÁRIA E CONSTRUÇÃO DO SOCIALISMO
}

\begin{abstract}
Se nós podemos trabalhar em associação, como estamos provando que podemos, então o futuro pode ser mais bonito, como jamais foi.

Trabalhadores da New Era Windows Cooperative (NEW ERA WINDOWS COOPERATIVE, 2012)
\end{abstract}

A transformação para uma relação social de caráter oposto, antagônico ao capitalismo, relação social coletiva e igualitária, só se faz quando os trabalhadores tomam conta de uma empresa. É aí que a auto-organização pode se tornar autogestão no sentido que nós damos hoje correntemente ao

termo.

João Bernardo (1999, p 38-9)

No primeiro capítulo desta dissertação mencionamos que, desde o final do século XX, um número cada vez maior de críticos do sistema social capitalista passou a acreditar que o caminho da superação desse sistema não é a tomada do poder estatal; nem pela força, nem por eleições. Nesse sentido, Paul Singer afirmou que as transformações desse século "subverteram a concepção (até então amplamente dominante) de que o caminho da emancipação passa necessariamente pela tomada do poder de Estado" (SINGER, 2002, p. 112). E João Bernardo defende que este momento representa o fim de um ciclo histórico e o início de outro, que se diferenciam pela consideração da "diferença prática entre relações sociais de produção e relações jurídicas de propriedade" (1999, p. 33-42).

Concordamos com essa visão e entendemos que o caminho real para superação do capitalismo é a criação de uma nova forma de organizar o processo produtivo, que também funcione em termos de possibilitar materialmente a vida humana, mas numa organização estruturada horizontalmente, com igualdade entre os produtores. E, para além disso, entendemos que o maior entrave, neste momento histórico, para a criação dessa nova forma de produzir não é a falta de um ambiente 
econômico global favorável, nem o estágio atual de desenvolvimento da tecnologia, mas a inexistência de um protótipo de micro-organização produtiva igualitária. Ou seja, um protótipo de empresa igualitária, horizontal, que também funcione em termos de produzir, mas sem criar desigualdade entre os produtores. Que gere, portanto, uma igualdade inerente na produção e, desse modo, a igualdade não dependa de posterior redistribuição. Sendo esse o maior entrave, entende-se porque nosso foco nas empresas recuperadas por trabalhadores: as tentativas de controle operário da produção - ou seja, experiências produtivas nas quais os envolvidos intencionam posicionar trabalhadores (operadores de atividades elementares) também como gestores e responsáveis por funções intelectuais - são contextos férteis para a criação histórica desse protótipo inexistente.

Quanto à opção pelo caminho da organização do processo produtivo, entendemos que essa é a única conclusão coerente que se pode obter a partir de uma interpretação materialista histórica dialética da realidade. Ou seja, uma interpretação que coloque o modo de produção da vida material como determinante último da estrutura política e jurídica e de suas formas correspondentes de consciência social ${ }^{60}$.

O caminho estatal não se sustenta.

Se o estado é uma estrutura que serve ao funcionamento da produção - e ele é - então "tomar o poder do estado" não significa, absolutamente, nada. Pois a fonte do poder não está no estado, nem nunca esteve. Como observa Paul Singer,

Não se trata de deixar a tomada do Estado pela classe operária num plano secundário, mas de indagar o que realmente significa isso. Parece-me evidente que nenhuma classe pode exercer diretamente o poder de Estado. Mesmo a burguesia não exerce este poder; são seus representantes que ocupam posições-chave no aparelho de Estado e eles são efetivamente seus representantes à medida que fazem o Estado dar cobertura à gestão econômica que a burguesia põe em prática (SINGER, 2008, p. 199-200).

Desse modo,

\footnotetext{
${ }^{60}$ Vale dizer que Marx foi contraditório sobre essa conclusão (como já mencionamos no primeiro capítulo, com base nas observações de Bourdet e Guillerm). Na verdade, arriscamo-nos a dizer que Marx nunca foi firme em suas afirmações relacionadas ao tema "como superar o capitalismo". A grande contribuição da obra de Marx foi explicar o capitalismo e o funcionamento material da sociedade. É preciso, é claro, entender o capitalismo para superá-lo. Mas não é suficiente. Essa ausência em Marx, entretanto, não deve nos preocupar. Ele foi um cientista genial e, talvez, sem ele, nós não compreenderíamos como o mundo capitalista funciona até hoje. No entanto, não faz sentido acreditar que ele entendeu tudo e tinha todas as respostas.
} 
O que a experiência histórica dos últimos seis ou sete decênios, tanto nos países capitalistas adiantados como nos países que tiveram revoluções, ensina é que a ideia de que a tomada do poder de Estado deve preceder a tomada do poder nas fábricas, escolas etc. é falsa. Quase poder-se-ia dizer que a tomada do poder de Estado antes que o poder tenha sido conquistado pela classe trabalhadora nos locais de produção é impossivel, porque não há como a classe trabalhadora poder assegurar sua representação em nível de governo enquanto o trabalho continuar alienado nas empresas. E a superação da alienação do trabalho produtivo, como a recente experiência da Polônia ainda mais uma vez mostrou, não se pode dar de um dia para o outro; é todo um processo de transformação da divisão do trabalho, da tecnologia e da mentalidade dos que participam do processo produtivo, que leva inevitavelmente um tempo bastante longo. [...] Isto significa que nenhuma "vanguarda", instalada no poder de Estado, pode (mesmo que queira) libertar a classe operária de cima para baixo (SINGER, 2008, p. 201-202).

Essa conclusão implica que não há poder real nas mãos do presidente da república, dos governadores, dos deputados; ou seja, daqueles que dirigem as estruturas de estado. Seu poder é apenas precário, obtido por delegação e permanentemente sujeito a revogação pelos detentores do poder real.

E quem detém esse poder em suas mãos é quem controla o processo produtivo. Que é, desde o século XVIII, a classe burguesa, o patronato, os empresários, os gestores das empresas capitalistas. São eles que organizam os processos que produzem nossas roupas, casas, comidas, computadores, instrumentos de trabalho e tudo o mais que consumimos em nosso cotidiano (por necessidade ou conveniência). Não só os processos mas, também, as pessoas que o operam. Por organizarem, eles controlam esses processos e essas pessoas. E, em consequência, controlam o mundo ${ }^{61}$.

A imensa força desse controle aparece de forma muito clara nos momentos históricos em que o conflito capital-trabalho se acirra. Na Inglaterra do século 1830, por exemplo, quando a organização sindical se consolidou e os trabalhadores

\footnotetext{
${ }^{61}$ A propósito, essa classe se caracteriza pela gestão e controle do processo produtivo, e não pela "propriedade dos meios de produção", como definiu Marx. É verdade que esses primeiros, em geral, coincidem com os proprietários, pois o direito de propriedade capitalista foi criado justamente para proteger a atividade de gestão capitalista. Sua característica fundamental, no entanto, que os caracteriza sociologicamente como classe, é serem gestores de empresas, e não proprietários. Entender essa diferença é fundamental para afastar a "expropriação" pelo estado como um caminho ao socialismo.
} 
organizaram grandes greves, uma larga porção da classe empresarial, agindo em resposta, realizou lockouts e demitiu trabalhadores sindicalizados ${ }^{62}$. É esse exatamente o momento em que o coletivo operário perde seu apoio, pois a comunidade se dirige a ele e pergunta; "Se você continuar essa greve, quem vai produzir as coisas?" Vemos isso claramente, também, no histórico caso Lip, que também apresentamos no primeiro capítulo.

E essa força se colocou, também, toda vez que um partido declaradamente revolucionário chegou ao governo, por golpe ou eleição. O patronato, amigo dos governantes comuns (porque esses últimos são seus assistentes), olharam para o revolucionário e disseram: "Sou eu que organizo a produção. O que vocês vão fazer comigo?" O "chefe de estado" tem alternativa senão continuar dando assistência? Não. A não ser que se entenda que trocá-lo por um gestor burocrata com base na ideia de que ele produzirá com mais responsabilidade social ou com melhor redistribuição posterior dos produtos da atividade é uma alternativa. Mas não é, pois não muda nada de fundamental. É esclarecedora a observação de Singer de que

[...] esta passagem do poder na produção do burguês ou tecnoburocrata ao trabalhador não pode ser feita por decreto ou por outro ato qualquer do Estado. Quem assume o poder de Estado, por mais que "queira" ser representante da classe operária, tem como responsabilidade primordial assegurar que a produção não se interrompa, que as necessidade materiais básicas da população continuem a ser satisfeitas. Em qualquer situação revolucionária esta necessidade de assegurar a produção se apresenta com o peso esmagador. Em consequência, o máximo que os "representantes" da classe operária no poder conseguem fazer é transferir o controle da produção das mãos da burguesia à de uma burocracia, a qual, para garantir a produção, passa a oprimir de fato os trabalhadores que continuam tão alienados quanto antes. Foi isso que aconteceu com todas as pseudotomadas do poder pela classe trabalhadora na Rússia, na Iugoslávia, na China, em Cuba etc. independentemente das intenções subjetivas dos dirigentes revolucionários (SINGER, 2008, p. 200-201).

Esse imenso poder dos gestores capitalistas, por sua vez, permite que eles organizem o mundo a sua maneira; ou, mais precisamente, à maneira que exige o modo de produção capitalista, que eles coordenam (e que os privilegia). O que significa dizer, no fundo, à maneira que exige o funcionamento de suas empresas (aplicadoras de seu protótipo de micro-organização produtiva). E isso implica, no fundamental, que o mundo deve ter duas características.

\footnotetext{
${ }^{62}$ Veja-se o tópico 1.1 do nosso primeiro capítulo.
} 
A primeira, uma hierarquia de níveis de habilidade intelectual, que, por ser necessária (ou seja, as pessoas não podem ter o mesmo acesso a desenvolvimento intelectual, sob pena de a produção não funcionar), deve ser mantida por um sistema escolar institucional e universal (é significativo o fato de a escola pública universal ter sido criada junto com a fábrica capitalista). E a segunda, operando combinada com a primeira, um contingente de postos de trabalho sempre menor do que o contingente de população qualificado e disposto a assumi-lo - o sistema de mercado de reserva, que Marx revelou n'O Capital.

Porque essas duas características? Para entender isso devemos olhar para dentro da empresa capitalista. A maior diferença desse núcleo produtivo com relação aos dos modos de produção anteriores é que ele precisa de um número grande de operadores pra funcionar. Isso foi uma inovação do capitalismo, consequência da invenção da máquina a vapor. É a grande inovação organizacional do sistema, pois, até esse momento histórico, cada núcleo produtivo funcionava com poucas pessoas; em geral, familiares. A consequência disso foi que era mais difícil organizar o processo. Para superar esse obstáculo, os gestores capitalistas inventaram, na prática, a organização empresarial capitalista: uma divisão de tarefas em que cada indivíduo operaria apenas uma parte da máquina e, consequentemente, um segmento do processo produtivo. Daí a palavra: operário. Essa invenção influenciou os projetistas de máquinas, que passaram a, cada vez mais, projetá-las para que fossem operadas de forma segmentada (é significativa, sobre isso, a proposição atual de Henrique Novaes no sentido de que as máquinas da fábrica capitalista não servem numa empresa igualitária sem adequações ${ }^{63}$ ). Mas é claro que a segmentação não poderia ser para todos, pois alguém tinha que coordenar o processo integral. Esse alguém era justamente o capitalista, em fábricas com 10 ou 20 operários. A partir de certo número, outros gestores tinham que ser colocados abaixo dele, por setor. Estava posta, então, a outra característica da organização empresarial capitalista: uma estratificação hierárquica rígida que diferencia os integrantes segundo o nível de exigência intelectual de suas atribuições. Com diversos níveis, mas apenas um ponto de cisão fundamental que divide a totalidade da empresa em duas atribuições básicas: gestão e operação.

63 Referimos-nos ao estudo "Processo de Adequação Sóciotécnica nas Fábricas Recuperadas brasileiras e argentinas", publicado pela editora Expressão Popular, em 2007, com o título O fetiche da tecnologia - a experiência das fábricas recuperadas. 
Essa é organização hierárquica rígida que, mais de um século depois, Taylor sistematizou e transformou em ciência (o que permitiu seu desenvolvimento), mas que já existia, na prática, em cada fábrica. $\mathrm{O}$ processo produtivo, então, estava fragmentado. Não pelo engenho de um gênio do mal, mas pelo engenho dos primeiros capitães de fábrica, para fazer frente a uma necessidade organizacional material. Foi assim que os primeiros capitalistas resolveram esse problema. Talvez houvesse outras formas de resolvê-lo, provavelmente existiam. Mas eles resolveram assim, e funcionou. E, por ter funcionado, nós passamos a depender disso.

O grande problema desse modelo de organização é que toda pessoa tem capacidade de pensar e, por isso, só se satisfaz enquanto pessoa humana quando desempenha tarefas que exigem o uso essa habilidade. E, por isso, não se satisfaz com o trabalho segmentado e deslocado da integralidade do processo (na expressão de Marx, alienado), pois ele é desestimulante. Então, este operário se amargura, se incomoda e, por vezes, se rebela. É demonstrativo disso o movimento luddista, pois ele foi deflagrado logo no início da consolidação do capitalismo, e consistia em um ato de pura rebeldia: quebrar máquinas. Ocorre que esses estados de espírito atrapalham o capitalista. Se o operário está amargurado, incomodado, triste, ou revoltado, ele não irá sentar e fazer seu trabalho elementar e sem sentido.

E então, neste momento, entra mais uma invenção dos patrões, a mais cruel de todas: o desemprego. Eles, agora já organizados em classe, verificam que só haveria uma maneira de fazer o operário ir para a fábrica, todos os dias, e sentar e trabalhar quieto: se ele acreditasse que não há alternativa para viver afora essa. Se ele estiver, portanto, sob ameaça permanente de ficar sem meios de se sustentar. Mas, para isso, para que possa ameaçá-lo com fundamento (e, realmente, dispensar os insubordinados), o capitalista deve ter sempre alguém no mercado humano disponível para substituí-lo; alguém sem emprego, mas querendo um, ou descontente com seu emprego, e querendo mudar. Ou seja: para todos os níveis da hierarquia, do jardineiro ao gerente de produção, o capitalista tem que ter permanentemente um contingente de trabalhadores disponíveis para ocupar o lugar do seu empregado. Mas, para isso funcionar na base da hierarquia, é necessário que uma proporção razoável de população tenha condições de vida muito ruins para servir de contingente de reserva para os piores trabalhos. Esse contingente de reserva não existia no início do capitalismo e, então, os empresários o criaram (no processo histórico que Marx 
chamou de acumulação primitiva ou formação do exército de reserva, que tem o êxodo rural forçado como manobra mais importante)..

A existência desse sistema de mercado de reserva humana - que, a propósito, pode ser verificada facilmente pela análise estatística da economia capitalista - significa algo perturbador: o grande motor que faz funcionar nosso mundo, hoje, é a ameaça de ficar sem meios de subsistência; não é a vontade de enriquecer, nem a busca por conferir sentidos à vida, nem a vontade de agir no mundo como ser social, mas o receio de ficar sem comida, roupas, casa. Esse é o motor, robusto e profundo, que move nosso sistema, presente em cada local de trabalho. Motor que é sutil no discurso, mas intensamente e claramente conhecido por cada um dos membros da classe trabalhadora.

Temos, por fim, os elementos fundamentais da empresa capitalista que a permitem funcionar: segmentação de tarefas, estratificação hierárquica com cisão entre gestores e operadores, e eterna ameaça de desemprego como estímulo do trabalho. Entendendo-os, podemos entender porque a estrutura do mundo necessária para o capitalista tem aquelas duas características: a hierarquia intelectual e o sistema de mercado de reserva.

Essa compreensão significa algo imensamente importante: é a organização interna da empresa capitalista que condiciona a organização externa do processo produtivo capitalista. O lugar fundamental do sistema capitalista, portanto, é o interior de cada fábrica, plantação, usina, e rede varejista. Todas as outras características globais do sistema - por exemplo, a tendência infinita à acumulação são decorrências da organização interna do seu núcleo produtivo.

Queremos dizer que a causa fundamental do fato, por exemplo, de $40 \%$ da população em idade de trabalhar do sudeste brasileiro (região mais industrializada do país) não ter concluído o ensino fundamental neste início de século XXI não é outra senão a satisfação das necessidades estruturais da micro-organização das empresas capitalistas do país.

Essa importância da organização interna da empresa já foi reconhecida por Singer, que colocou que

A luta pelo socialismo almeja, hoje em dia, não tanto a abolição da propriedade privada dos meios de produção que, no capitalismo 
monopólico, se tornou pouco mais que uma ficção jurídica (os donos das grandes empresas são incontáveis acionistas, com quase nenhum poder de decisão), mas a eliminação da hierarquia de mando nas unidades de produção e distribuição. O que implica a criação de forças produtivas fundamentalmente diferentes das que existem hoje, que não se apoiarão mais na separação entre trabalho intelectual e trabalho manual mas na sua reunião num corpo de trabalhadores, cujos participantes realizarão, todos, um e outro tipo de trabalho" (SINGER, 2008, p. 183, grifo nosso).

E é reconhecida, também, por João Bernardo, quando afirma que

A transformação para uma relação social de caráter oposto, antagônico ao capitalismo, relação social coletiva e igualitária, só se faz quando os trabalhadores tomam conta de uma empresa. É aí que a auto-organização pode se tornar autogestão no sentido que nós damos hoje correntemente ao termo (1999, p 38-9).

Essa conclusão implica que a transformação do mundo é, antes de tudo, a transformação da fábrica. Construir um mundo sem as mazelas do capitalismo passa necessariamente por construir uma fábrica que produza a partir de uma estrutura diferente. A fábrica, núcleo da produção, é o protótipo do mundo. $\mathrm{O}$ mundo é seu reflexo no sentido de que a estratificação desigual da fábrica causa a estratificação desigual do mundo. Por isso, resolver o problema da barbárie no mundo é, em primeiro lugar, resolver o problema da desigualdade na fábrica.

Há diversas outras consequências derivadas dessa forma de entender o sistema. Entre elas, queremos destacar a ressignificação da teoria marxista da extração de mais-valor, para incluir nela o papel da gestão da produção.

Marx explicou que, no funcionamento da empresa capitalista, o trabalho do assalariado resulta na criação de um valor que é menor do que o salário repassado pelo empresário. Que, por isso, quanto maior o número de empregados maior o lucro do capitalista. E, ainda, que disso decorre que o assalariamento se constitui em um processo de exploração. Essas são descobertas incontestáveis.

No entanto, isso levou Marx a afirmar que a extração desse mais-valor seria uma espécie de apropriação indevida, um "roubo", pois esse valor pertenceria, legitimamente, ao trabalhador. Mas esse entendimento carece de melhor elaboração. A verdade é que o que permite, de fato, que o capitalista se aproprie desse resultado produzido a partir do trabalho do operário é sua posição de gestor do processo produtivo. 
A gestão é o trabalho intelectual por excelência de cada núcleo produtivo. No entanto, parece que sua importância foi menosprezada pelo grande crítico do capitalismo. Porque, ao contrário do que se poderia pensar pela leitura da literatura de esquerda, uma atividade produtiva não funciona sozinha. A produção de uma mesa, por exemplo, não necessita apenas de madeira, parafusos, uma máquina, um engenheiro e um operador. Ela necessita, também, de atos de movimentação e organização interna e externa, como decisões sobre como produzir e o que produzir, busca de fornecedores, relações com compradores. Ou seja, atos de gestão. E é errado supor - como supuseram aqueles que defenderam sinceramente a planificação econômica socialista - que esses atos são elementares e possam ser mecanizados, de modo que a economia passasse a funcionar "exatamente como deve". As relações sociais humanas são complexas, incluindo as econômicas. Não é possível sequer entendê-las sob uma perspectiva mecânica; quanto mais fazê-las funcionar. Esse, a propósito, é um condicionante que se coloca de maneira muito forte nas experiências de controle operário da produção. E, também, é o que permite que o assalariado seja facilmente substituível por outro, mas o empresário, nem tanto. Aquele que pratica o trabalho de gestão, portanto, controla o processo. E, por controlá-lo, detém o poder sobre ele. É essa a origem de nossa dependência atual dos capitalistas e, pela mesma razão, também da sua dominação sobre a nossa vida social ${ }^{64}$.

Entendemos nesse sentido a afirmação de João Bernardo de que o novo ciclo histórico, que se iniciou no fim do século passado, caracteriza-se pelo conflito entre duas formas de organização, ou de relações sociais de produção: a autoorganização e a hetero-organização. Um "novo grande ciclo [...] em que o tema básico é a gestão e o controle" (BERNARDO, 1999, p. 42).

Assim, o que confere ao capitalista o poder de extrair mais-valor é seu trabalho de gestão do processo produtivo, pois esse trabalho lhe confere poder, inclusive, de pagar a cada trabalhador o mínimo que é possível pagar de acordo com o funcionamento do mercado humano capitalista, independentemente de quanto seu trabalho produziu. Isso não quer dizer que esse trabalho legitima a extração de mais-

\footnotetext{
${ }^{64} \mathrm{O}$ modelo de gestão da produção tem, na verdade, uma importância fundamental em todo modo de produção. Valeria a pena pensar se, na afirmação de Marx e Engels de que cada modo de produção da história tem seu modelo característico de propriedade, não caberia substituir a palavra "propriedade" pela palavra "gestão". A propriedade, a nosso ver, é apenas uma forma jurídica destinada à proteção do modelo de gestão. Portanto, sua consequência, e não sua causa.
} 
valor. Mas sim que, de fato, o trabalho de gestão lhe dá esse poder real, independentemente do que se pense disso.

Essa conclusão implica outra: se queremos tirar o poder sobre o mundo das mãos dos capitalistas, devemos, entre outras coisas, substituir seu trabalho de gestão produtiva, para conseguirmos controlar a produção. Apenas essa substituição pode acabar com nossa dependência.

E chegamos, neste ponto, à questão do que significa construir o protótipo da produção em igualdade. Devemos saber que de nada adiantaria substituir o capitalista por outro gestor ("socialista") e manter a organização vertical. O problema é justamente essa organização vertical e o fato de a gestão se concentrar nas mãos de uma cúpula enquanto o restante realiza trabalhos elementares, alienados e desestimulantes. Pois essa é a origem de todas as mazelas. Sobre essa questão queremos dizer, apenas, que construir esse protótipo histórico significa criar um sistema de divisão do trabalho que resulte em uma equalização nas responsabilidades e da importância de todos os produtores. E, por consequência, na dependência equalizada do processo com relação a todos.

Finalizamos nosso ensaio por aqui. Com este capítulo, que é apenas um ensaio, não pretendemos construir conclusões (que não cabem, absolutamente, neste trabalho jurídico), mas, apenas, levantar questões que pretendemos desenvolver no futuro. Questões relacionadas a duas hipóteses, em especial: a da inexistência de um protótipo de organização empresarial igualitária como maior entrave à superação do capitalismo deste momento histórico; e a da centralidade do trabalho de gestão da produção como fonte da dominação da classe capitalista sobre a classe trabalhadora e a vida social em geral. Saber se essas hipóteses se confirmam, ou não, será fundamental para que possamos prosseguir, neste século, com o projeto de superação e eliminação do sistema social capitalista. 


\section{CONCLUSÕES}

No início de nosso trabalho, em abordagem histórica, verificamos que há uma história paralela que acompanhou a vida do sistema social capitalista: a história da recuperação de fábricas por trabalhadores. Sua trajetória passa pelos precoces movimentos operários ingleses da primeira metade do século XIX, pela paradigmática ocupação da fábrica de relógios Lip Watch, em 1973, na França, pela explosão de ocupações nos países da América Latina, na primeira década do século $\mathrm{XX}$ e pelos resultados atuais da grave crise econômica mundial que estourou em 2008, com novas ocupações no Brasil e, também, em países como Grécia, Espanha e Estados Unidos. Há, portanto, um movimento histórico de anseio global da classe trabalhadora por controlar a produção. E, atualmente, o centro mundial desse movimento está na América Latina, tendo a Argentina como sede mais avançada.

É justificável e relevante realizar estudos que favoreçam esse fenômeno, tendo em vista que ele se coloca, cada vez mais, com o potencial de abrir novos caminhos de desenvolvimento para a classe trabalhadora.

No âmbito jurídico, tomamos como problema o fato de que os coletivos de trabalhadores brasileiros que, nos dias de hoje, resolvem assumir empresas falidas de seus patrões enfrentam um grande problema: a carência de respostas estáveis, favoráveis e eficazes às questões jurídicas que surgem no desenrolar de sua empreitada. Trata-se de um problema de grande relevância, tendo em visa que questões jurídicas se colocam ao longo de todo o processo de recuperação de empresas e são, muitas vezes, determinantes de seu êxito ou fracasso.

Em nosso estudo, identificamos que são quatro as problemáticas jurídicas centrais enfrentadas pelas ERTs: a) a licitude da greve de ocupação; b) a necessidade de reconhecimento da gestão operária no procedimento de falência e recuperação empresarial; c) a necessidade, em médio e longo prazo, de estabilização jurídica do ente coletivo, por meio da constituição de uma forma jurídica adequada e d) a carência, em geral, de outras políticas públicas específicas, especialmente as que possibilitem o acesso a crédito. 
O presente trabalho procurou contribuir para a superação desses pontos problemáticos.

Antes de iniciar o embate propriamente jurídico, no segundo capítulo, procuramos demonstrar, a partir de aportes marxistas, que a atuação das instituições jurídicas junto aos conflitos sociais e econômicos que se dão entre a classe empresarial capitalista e a classe trabalhadora têm um caráter contraditório e classista. Longe de ser o espaço da conciliação racional e neutra dos "interesses gerais" com vistas ao "bem comum", a instância jurídica é, na verdade, uma arena social conflituosa forjada na luta de classes e, portanto, em última instância, favorável aos interesses da classe dominante. Apontamos, entretanto, que, ainda assim, as formulações jurídicas mais progressistas podem servir como instrumentos de luta para a classe trabalhadora.

Em nossa análise jurídica, que ocupou o terceiro capítulo, voltamo-nos para dois pontos principais: em primeiro lugar, os princípios constitucionais que são a base fundamental para o enfrentamento de todas as questões que envolvem o fenômeno; e, em segundo, a questão da licitude da greve de ocupação.

Na primeira parte, começamos por uma abordagem do conteúdo dos três princípios constitucionais que têm relação fundamental com as questões jurídicas que emergem nos processos de recuperação operária: o princípio da função social da propriedade, o princípio do valor social do trabalho e da livre iniciativa e o princípio do direito ao trabalho. Depois, vimos que, à luz dos postulados hermenêuticos contemporâneos, identificados pela signo do pós-positivismo, é adequado e esperado o reconhecimento de que a Constituição e os princípios jurídicos são dotados de força normativa e imperatividade jurídica. Portanto, no âmbito dos conflitos jurídicos emergentes nas recuperações operárias, podemos concluir que esses três princípios constitucionais têm efeitos imediatos sobre casos concretos de recuperação. Em seguida, em aprofundamento desse estudo, concluímos que existem pelo menos quatro efeitos jurídico-positivos que devem decorrer desses princípios constitucionais com relação a esse tema. Os efeitos consistem em mandamentos vinculantes aos atores estatais para:

1. Criar leis dedicadas às recuperações operárias que: garantam a liberdade de iniciativa econômica do coletivo operário (artigo $1^{\circ}, \mathrm{IV}, \mathrm{CF}$ ), 
protejam o trabalho e a fonte de renda dos operários auto-organizados (artigo $1^{\circ}, \mathrm{IV}$, e $6^{\circ}, \mathrm{CF}$ ), privilegiem os trabalhadores como controladores das empresas em crise que cumprem melhor a função social da empresa e dos bens de produção (artigo 170, III, CF) e prevejam sanções para os empresários capitalistas que violam a função social dos bens de produção (artigo 170, III, CF).

2. Desenvolver políticas públicas dedicadas às recuperações operárias que: favoreçam as iniciativas econômicas do coletivo operário (com programas de acesso a crédito, por exemplo) (artigo $1^{\circ}, \mathrm{IV}, \mathrm{CF}$ ), e forneçam suporte às recuperações por serem fonte de trabalho e renda para os operários auto-organizados (artigo $1^{\circ}$, IV, e $6^{\circ}, \mathrm{CF}$ ) e por cumprirem melhor a função social da empresa e dos bens de produção (artigo 170, III, CF).

3. Não realizar atos contrários às recuperações sem justificativas constitucionais, se elas se constituírem em materialização dos três princípios (como, em geral, se constituem). Ou seja, se elas se constituírem como: a) expressão da liberdade de iniciativa econômica e, em especial, de iniciativa econômica não-capitalista (artigo $1^{\circ}, \mathrm{IV}$, $\mathrm{CF}$ ); b) meio de proteção e garantia de trabalho e renda (artigo $1^{\circ}, \mathrm{IV}$, e $\left.6^{\circ}, \mathrm{CF}\right)$; c) e, também, meio de promoção de um melhor cumprimento da função social da empresa e dos bens de produção (artigo 170, III, CF). Além disso, os agentes jurídicos também estão proibidos de desfavorecer os recuperadores operários em favor dos empresários capitalistas que tenham praticado atos ilegais ou antissociais e, com isso, violado a função social da empresa e da propriedade dos bens de produção (artigo 170, III, CF).

4. E, por último, interpretar a legislação, no tratamento dos casos de recuperação, considerando a influência vinculante desses três princípios. Ou seja, os agentes do direito, na tarefa de interpretar as leis incidentes sobre os casos de recuperação (por exemplo, a lei de greve, lei de falências, lei das cooperativas, lei de execução fiscal, lei processual civil e do trabalho etc.), ao se depararem com dúvidas quanto ao sentido de 
uma norma, lacunas normativas ou contradição entre normas, devem optar pela interpretação que aja no sentido de: garantir a liberdade de iniciativa econômica do coletivo operário (artigo $1^{\circ}, \mathrm{IV}, \mathrm{CF}$ ); e favorecer as recuperações enquanto fontes de trabalho e renda para os operários auto-organizados (artigo $1^{\circ}$, IV, e $6^{\circ}$, CF) e meio de melhor cumprimento da função social da empresa e dos bens de produção (artigo 170, III, CF); e sancionar os atos empresariais ilegais ou antissociais que violem a função social da empresa e dos bens de produção (artigo 170, III, CF). Além disso, ao interpretar a legislação, esses atores estatais deverão reconhecer a inconstitucionalidade e a consequente invalidade jurídica de normas ou atos oficiais contrários a esses princípios, caso nenhum outro princípio constitucional suporte a legitimidade dessas normas ou atos oficiais.

Na segunda parte do terceiro capítulo, abordamos a licitude das greves de ocupação, analisando, em primeiro lugar, a greve de ocupação passiva - aquela que objetiva apenas aumentar a pressão das reivindicações, mas não tomar a produção -, concluímos que ela será lícita como expressão da autotutela coletiva operária se atender apenas aos requisitos básicos de licitude de qualquer greve, a saber: a não violência, o caráter coletivo, a abstenção de trabalho e o caráter provisório (artigo $2^{\circ}$ da Lei de Greve).

Isso porque, se o coletivo operário, utilizando-se de seus mecanismos democráticos clássicos - a assembleia geral, em especial -, decide que a continuidade da greve necessitará de um piquete, uma vigília, um acampamento ou uma ocupação, essa decisão deve ser respeitada pelo judiciário e demais agentes estatais, pois a ofensividade faz parte do instituto da greve, que é protegido pelo artigo $9^{\circ}$ da Constituição.

Quanto à greve de ocupação ativa - aquela que se dá com a intenção de tomar a produção - vimos que, em muitos casos de ERT, ela foi uma medida fundamental para o sucesso da recuperação. E verificamos que, para a análise de sua licitude, o agente jurídico deve enfrentar dois pontos: em primeiro lugar, saber se o ato se qualifica como uma greve (e, portanto, recebe proteção constitucional); e, em segundo, se, e em que condições, o ato será lícito, a partir de uma leitura que 
considere a influência do princípio constitucional da função social da propriedade dos bens de produção.

Desenvolvendo esse raciocínio, concluímos, em primeiro lugar, que a greve ativa - ou seja, a greve com ocupação para produzir - é modalidade de greve protegida pelo artigo $9^{\circ}$ da Constituição, diante de seu texto eclético, garantidor de toda ação coletiva e organizada de trabalhadores em reação ao trabalho subordinado.

Em segundo, que carece de legitimidade qualquer análise da licitude de uma greve ativa fundamentada na Lei n. 7.783/89, tendo em vista que seu complexo normativo desconsidera absolutamente a realidade desse fenômeno social e as questões jurídicas e sociais que dele emergem. Que, portanto, o analista deve pautar sua análise em outras fontes normativas.

Em terceiro, que tal modalidade de greve, se analisada a partir de um confronto com os princípios da Constituição à luz da Teoria dos Direitos Fundamentais, deve ser qualificada como lícita, se for deflagrada como resposta a uma crise aguda na empresa, gerada por má gestão ou acompanhada de atos de má-fé empresarial (atos que implicam numa violação grave das responsabilidades sociais estabelecidas pela ordem jurídica para o controlador de bens de produção.). Isso porque, nessas condições, a importância da satisfação dos princípios constitucionais favorecidos (direito ao trabalho, valor social do trabalho e função social da propriedade) é maior que a importância da afetação dos princípios constitucionais desfavorecidos (direito de propriedade e valor social da livre iniciativa).

No capítulo seguinte, por fim, dedicamos um breve espaço à exposição dos dois principais avanços normativos favoráveis ao desenvolvimento das ERTs alcançados na América Latina: a Ley n. 26.684/2011, da Argentina, que introduziu no procedimento falimentar nacional o reconhecimento sistemático da possibilidade de recuperação operária de empresas; e o Decreto n. 165/2006, do Uruguai, que tornou positiva a licitude da greve com ocupação de locais de trabalho.

A intenção deste trabalho é, como colocamos no início, contribuir para o desenvolvimento desse grande movimento histórico de recuperação de empresas por trabalhadores. Desejamos que a análise aqui construída possa auxiliar coletivos operários que tenham ocupado ou que se proponham a ocupar empresas em crise, 
fornecendo informações e fundamentos jurídicos para suas ações e seus requerimentos perante os órgãos estatais. Acreditamos que caminhos jurídicos menos espinhosos podem contribuir para a consolidação das experiências atuais e, para além disso, encorajar novos empreendimentos de recuperação operária. 


\section{REFERÊNCIAS}

ALONSO, Liliana Teresita Negre de. Algunos aspectos sobre la reforma a la ley concursal No 26.684. In: Revista Argentina de Derecho Laboral y de la Seguridad Social, 22-03-2012. Disponível em: $<$ http://www.ijeditores.com.ar/articulos.php?idarticulo=48917\&print=2>. Acesso em: $12 / 12 / 2013$.

ALVES, Alaôr Caffé. Estado e ideologia: aparência e realidade. São Paulo: Editora Brasiliense, 1987.

ANTIERO, Javier; ELENA, Paloma; RUGGERI, Andrés. El movimiento obrero argentino y las empresas recuperadas por los trabajadores. Cuadernos para la autogestión n. 4. Buenos Aires: Ediciones de la Cooperativa Chilavert, 2012.

AROUCA, José Carlos. Repensando o sindicato. São Paulo: LTr, 1988.

AZZELLINI, Dario; NESS, Immanuel (org.). Ours to Master and to Own: Workers' Control from the Commune to the Present. Chicago, IL: Haymarket Books, 2011.

BARCELlOS, Ana Paula de; BARROSO, Luís Roberto. O começo da História: a Nova Interpretação Constitucional e o Papel dos Princípios no Direito Brasileiro. In: SILVA, Virgílio Afonso da (org.). Interpretação Constitucional. 1. ed. 3. tir. São Paulo: Malheiros Editores, 2010.

BARROSO, Luís Roberto. Interpretação e aplicação da Constituição: fundamentos de uma dogmática constitucional transformadora. 6. ed. São Paulo: Saraiva, 2004.

BAS, Francisco Junyent. Alrededor de las principales directrices de la reforma al estatuto concursal por la ley 26.684. In: Revista de la Facultad de Derecho, Vol. III, n. 1 Nueva Serie II (2012), p. 53-80. Universidad Nacional e Córdoba. Disponível em: http://www.revistas.unc.edu.ar/index.php/refade/article/view/5968/6865. Acesso em: $12 / 12 / 2013$.

BERNARDO, J. Autogestão e socialismo. In: Democracia e autogestão. Temporaes / Departamento de História. Faculdade de Filosofia, Letras e Ciências Humanas. Universidade de São Paulo. v. 1. São Paulo: Humanitas/ FFLCH/ USP, 1999. 
BORGES, Altamiro. Origem e papel dos sindicatos. I Modulo do Curso Centralizado de Formação Política - Escola Nacional de Formação da CONTAG - ENFOC Brasília, 14 a 25 de agosto de 2006. Disponível em: < http://contag.org.br/imagens/Origemepapeldossindicatos-AltamiroBorges.pdf $>$ Acesso em: 09/12/2013. Agosto de 2006.

BOURDET, Yvon; GUILLERM, Alain. Autogestão: uma mudança radical. Rio de Janeiro: Zahar Editores, 1976.

BRIGNONI, Hugo Fernández; ROOCA, Danubio Moreira. La huelga como un derecho fundamental y sus posibilidades de conflicto con otros derechos fundamentales de los ciudadanos. XX Congreso Mundial Derecho del Trabajo y Seguridad Social. Chile, 2012. Disponível em: < http://www.congresomundialtrabajo2012.com/wp-content/uploads/2011/ 01/Hugo-Fern\%C3\%A1ndez-Brignoni-Danubio-Moreira-Rocca1.pdf>. Acesso em: $07 / 01 / 2014$.

BUSHEI, Claire. Republic Windows comes back as worker-owned venture. In: Crain's Chicago Business. May 07, 2013. Disponível em: <http://www.chicagobusiness.com/article/20130507/NEWS05/130509797/republic>. Acesso em: 30/12/2013.

CANOtilho, Joaquim J. Gomes. Direito Constitucional e Teoria da Constituição. 7. ed. Coimbra: Almedina, 2003.

CASTELLO, Alejandro. O direito de greve no Uruguai. In: Revista Meritum, Belo Horizonte - v. 8 - n. 1 - p. 43-76 - jan./jun. 2013. Disponível em: < http://www.fumec.br/revistas/index.php/meritum/article/viewFile/1780/1151>. Acesso em: 06/01/2014.

CHAUÍ, Marilena. O que é ideologia. 2. ed. São Paulo: Brasiliense, 2008.

COMPARATO, Fábio Konder. Função social da propriedade dos bens de produção. Revista de Direito Mercantil, Industrial, Econômico e Financeiro. São Paulo. n. 63. Julho/setembro de 1986. pp. 71-79.

COMPARATO, Fábio Konder. Ética: direito, moral e religião no mundo moderno. São Paulo: Companhia das Letras, 2006.

DAGNINO, Renato; NOVAES, Henrique Tahan. Prefácio. In: HENRIQUES et al. 
Empresas recuperadas por trabalhadores no Brasil. Rio de Janeiro: Multifoco, 2013.

DALLARI, Dalmo de Abreu. Independência da magistratura e Direitos Humanos. In: Associação Juízes para a Democracia. Direitos Humanos: visões contemporâneas. São Paulo: Associação Juízes para a Democracia, 2001.

DELGADO, Maurício Godinho. Direito coletivo do trabalho. São Paulo: LTr, 2001.

DIEESE. Balanço das greves em 2012. In: Estudos e pesquisas, n. 66, maio de 2012. Disponível em: < http://www.dieese.org.br/balancodasgreves/2012/estPesq66balanco greves2012.pdf >. Acesso em: 05/01/2014.

DWORKIN, Ronald. Taking Rights Seriously. Cambridge: Harvard University Press, 1978.

ED. Workers at Vio.Me factory in Northern Greece vote for factory self-management. Libcom.org. 10 de julho de 2012. Disponível em: < http://libcom.org/news/workersmining-industry-factory-northern-greece-vote-factory-self-management-10072012>. Acesso em: 05/01/2014.

FAJN, Gabriel (coord.). Fábricas y empresas recuperadas: protesta social, autogestión y rupturas em la subjetividad. Centro Cultural de la Cooperación / Departamento de Ciencias Sociales / Area de Investigación. Buenos Aires: Ediciones del Instituto Movilizador de Fondos Cooperativos C. L., 2003.

FELICIANO, Guilherme Guimarães. Dos princípios do Direito do Trabalho no Mundo Contemporâneo. In: Revista do Tribunal Regional do Trabalho da $15^{a}$ Região, São Paulo, n. 27, 2005, p. 85-105. Disponível em: <http://www.trt15.jus.br/escola_da_magistratura/Rev27 Art5.pdf>. Acesso em: 12.05.2011.

Das cooperativas na perspectiva luso-brasileira: comercialidade e participação social: o que são, o que podem e o que não devem ser. São Paulo: LTr, 2009.

FLANDERS, LAURA. New Era Windows Cooperative is open for business in Chicago. Workerscontrol.net. 29 de Maio de 2013. Disponível em: < http://www.workerscontrol.net/pt-pt/node/316 >. Acesso em: 19/11/2013.

GARCIA, Ivan Simões. Neoconstitucionalismo, Nova Hermenêutica e o Direito do Trabalho. In: MOREIRA, Eduardo Ribeiro; GONÇALVES JUNIOR, Jerson Carneiro; BETTINI, Lucia Helena Polleti. Hermenêutica Constitucional - Homenagem aos 22 anos 
do Grupo de Estudo Maria Garcia. Florianópolis: Conceito Editorial, 2010.

GIAMBELLUCA, Liliana. Zanon: Ganó la disciplina ceramista. In: Agencia Rodolfo Walsh. Lunes, 12 de Noviembre de 2012. Disponível em: $<$ http://www.agenciawalsh.org/movimiento-obrero/e-r/9576-neuquen.html>. Acesso em: 24.07.2013.

GRAU, Eros Roberto. A Ordem Econômica na Constituição de 1988. 14. ed. São Paulo: Malheiros Editores, 2010.

GUIMARÃES, Gonçalo (org.). Sindicalismo e cooperativismo: a economia solidária em debate - trasnformações no mundo do trabalho. Rio de janeiro: UNITRABALHO, 1999. HENRIQUES, Flávio Chedid; SÍGOLO, Vanessa Moreira; RUFINO, Sandra; ARAÚJO, Fernanda Santos; NEPOMUCENO, Vicente; GIROTO, Mariana Baptista; PAULUCCI, Maria Alejandra; RODRIGUES, Thiago Nogueira; ROCHA, Maíra Cavalcanti; FARIA, Maurício Sardá de. Empresas recuperadas por trabalhadores no Brasil. Rio de Janeiro: Multifoco, 2013.

HESSE, Konrad. A força normativa da Constituição. Porto Alegre: Sergio Antonio Fabris Editor, 1991.

HOBSBAWM, Eric J. Era dos extremos: o breve século XX: 1914-1991. 2. ed. São Paulo: Companhia das Letras, 1995.

KELSEN, Hans. Teoria pura do direito. 6. ed. São Paulo: Martins Fontes, 1998.

KLEIN, Naomi. Cuando trabajar es un delito. In: MAGNANI, Esteban. El cambio silencioso: empresas y fábricas recuperadas por los trabajadores em la Argentina (Prólogo). Buenos Aires: Prometeo Libros, 2003.

LÓPEZ-MONÍS DE CAVO, Carlos. O direito de greve: experiências internacionais e a doutrina da OIT. São Paulo: LTr/IBRART, 1986.

MAGNANI, Esteban. El cambio silencioso: empresas y fábricas recuperadas por los trabajadores en la Argentina. Buenos Aires: Prometeo Libros, 2003.

MAI, Cahiers de. The Lip Watch Strike. In: Radical America, volume 7, n. 6, NovemberDecember 1973. Massachusetts-EUA, 1973.

MANDL, Alexandre Tortorella. O Movimento das Fábricas Ocupadas e o Direito. In: 
Revista do Cemop nº 02. CEMOP: Sumaré-SP, out/2011.

MANDL, Alexandre Tortorella. 10 anos do Movimento das Fábricas Ocupadas. Portal da Esquerda Marxista. Disponível em: < http://marxismo.org.br/?q=content/10-anos-domovimento-das-fabricas-ocupadas>. Acesso em: 09/12/2013. Dezembro de 2012.

MARX, Karl; ENGELS, Friedrich. Manifesto comunista. São Paulo: Boitempo Editorial, 1998.

MELO, Tarso de. Direito e ideologia: um estudo a partir da função social da propriedade rural. São Paulo: Expressão Popular, 2009.

MIAILLE, Michel. Introdução crítica ao direito. 3. ed. Lisboa: Editorial Estampa, 2005.

NAPOLEÃO, Fábio. Cipla (Joinville-Brasil): a luta dos trabalhadores contra o desemprego. $\quad$ UDESC, $2005 . \quad$ Disponível em: http://www.fabricasocupadas.org.br/cmo/index.php?option=com_docman\&task=doc_view $\&$ gid=23\&tmpl=component $\&$ format=raw \&Itemid=2> . Acesso em: 20/12/2013.

NEFFA, Julio César. Improvement of working conditions and environment: a Peruvian experiment with new forms of work organisation. In: International Labour Review. JulyAugust 1981.Vol. 120. n. 4.

NEW ERA WINDOWS COOPERATIVE. Our story. Disponível em: < http://www.newerawindows.com/about-us/our-story >. Acesso em: 19/11/2013.

NOVAES, Henrique Tahan. De Tsunami a marola: uma breve história das Fábricas Recuperadas na América Latina. In: Revista Lutas \& Resistências / publicação do Grupo de Estudos de Política da América Latina, Programa de Pós-Graduação em Ciências Sociais, Universidade Estadual de Londrina - n.2, p. 84-97, $1^{\circ}$ semestre de 2007.

OLIVEIRA, LUCIANO. Os excluídos 'existem'? notas sobre a elaboração de um novo conceito. Revista brasileira de Ciências Sociais. v. 12 . n. 33 . São Paulo, fev/1997. Disponível em: <http://www.anpocs.org.br/portal/publicacoes/rbcs_00_33/rbcs33_04>. Acesso em: 02/12/2013.

OPEN INITIATIVE OF SOLIDARITY AND SUPPORT. The factory of Vio.Me (Industrial Mineral) starts production under workers' control! Fevereiro de 2013. Disponível em: < http://www.viome.org/2013/02/the-factory-of-viome-industrialmineral.html>. Acesso em: 18/11/2013. 
ORTELlADO, P. A autogestão do capital. In: Democracia e autogestão. Temporaes / Departamento de História / Faculdade de Filosofia, Letras e Ciências Humanas / Universidade de São Paulo. v. 1. São Paulo: Humanitas/ FFLCH/ USP, 1999.

PEDREIRA, PINHO. A greve com ocupação de locais de trabalho. In: Revista da Academia Nacional de Direito do Trabalho. Greve. Ano I - n. 1 - 1993. São Paulo, 1993.

RADICAL AMERICA. The Lip Watch Strike - introdução e postscript do editor. In: Radical America, volume 7, n. 6, November-December 1973. Massachusetts-EUA, 1973.

RIBEIRO, Fernando J. Armando. O princípio da função social da propriedade e a compreensão constitucionalmente adequada do conceito de propriedade. In: Revista Virtuajus - Faculdade de Direito da PUCMINAS. Ano 2, n. 2. Dezembro/2003. Disponível em <http://www.fmd.pucminas.br/Virtuajus/ano2_2/O\%20principio\%20da\%20\%20funcao .pdf>. Acesso em: 02/01/2013.

RICCI, Francesco. Trotsky e a Itália de 1920. Liga Internacional dos Trabalhadores Quarta Internacional. 22 de Agosto de 2010. Disponível em: < http://www.litci.org/pt/index.php?option=com_content\&view=article\&id=2077:trostky-ea-italia-de-1920>. Acesso em: 19/11/2013.

RUGGERI, Andrés et al. Las empresas recuperadas em la Argentina: informe del tercer revelamiento de empress recuperadas por sus trabajadores. Buenos Aires: Ediciones de la Cooperativa Chilavert, 2011.

RUGGERI, Andrés; WERTHEIMER, Marina; GALEAZZI, Cecilia; GARCÍA, Fernando. Autogestión y cooperativismo. Cuadernos para la autogestión n. 1. Buenos Aires: Ediciones de la Cooperativa Chilavert, 2012.

SANTOS, Boaventura de Souza (org.). Produzir para viver: os caminhos da produção não capitalista. 3. ed. Rio de Janeiro: Civilização Brasileira, 2012.

SANTOS, Ronaldo Lima dos. Interditos proibitórios e direito fundamental de greve. In: Justiça do Trabalho. Ano 28 - n. 325 - Janeiro/2011. Porto Alegre, 2011.

SILVA, José Afonso da. Aplicabilidade das normas constitucionais. 2. ed. São Paulo: Revista dos Tribunais, 1982.

SINGER, Paul. Uma utopia militante: repensando o socialismo. Petrópolis-RJ: Vozes, 1998. 
SINGER, P. Autogestão e socialismo: oito hipóteses sobre a implantação do socialismo via autogestão. In: Democracia e autogestão. Temporaes / Departamento de História. Faculdade de Filosofia, Letras e Ciências Humanas. Universidade de São Paulo. v. 1. São Paulo: Humanitas/ FFLCH/ USP, 1999.

SINGER, Paul. Introdução à Economia Solidária. 1.ed. São Paulo: Editora Fundação Perseu Abramo, 2002.

SINGER, Paul. Aprender economia. 24.ed. São Paulo: Contexto, 2008.

SINGER, Paul. A recente ressurreição da economia solidária no Brasil. In: SANTOS, Boaventura de Souza (org.). Produzir para viver: os caminhos da produção não capitalista. 3. ed. Rio de Janeiro: Civilização Brasileira, 2012.

SOUTO MAIOR, Jorge Luiz. Greve. In: LTr: suplemento trabalhista. Ano 28 - n. 124. São Paulo, 2012.

THE CLINIC ONLINE. Obreros griegos toman control de fábrica y comienzan a distribuir producción para superar la crisis. EFE/The Clinic Online. 29/06/2013. Disponível em: < http://www.theclinic.cl/2013/06/29/obreros-griegos-toman-control-defabrica-y-comienzan-a-distribuir-produccion-para-superar-la-crisis/>. Acesso em: 18/11/2013.

THE WORKING WORLD. About us. Disponível em: < http://www.theworkingworld.org/us/about-us/ >. Acesso em: 19/11/2013.

TRAGTENBERG, Maurício. Autonomia operária. São Paulo: Editora Unesp, 2011.

URIARTE, Oscar Ermida. La nueva legislación laboral uruguaya. In: IUSLabor revista eletrónica, 04/2006. Universitat Pompeu Fabra - Barcelona/Espanha. Disponível em: <http://www.upf.edu/iuslabor/042006/LatinoamericaOscarErmida.pdf>. Acesso em: $12 / 12 / 2013$.

VERAGO, Josiane Lombardi. Trajetórias de trabalhadores de fábricas ocupadas e geridas na perspectiva do "controle operário" - Brasil e Argentina. I Seminário Internacional de História do Trabalho. V Jornada Nacional de História do Trabalho. UFSC. Outubro de 2010a. Disponível em: $<$ http://www.memoriaoperaria.org.br/index.php?option=com_docman\&task=doc_downloa d\&gid=39\&Itemid=27> . Acesso em: 05/01/2014. 
VERAGO, Josiane Lombardi. Fábricas ocupadas e controle operário - Brasil e Argentina (2002-2010). Universidade de São Paulo - Programa de Pós-Graduação em Integração da América Latina. Tese de Doutorado. São Paulo, 2010 b.

VILCHEZ, Iliana Irupé Fernández. Estudio sobre los aspectos legales de las empresas recuperadas por sus trabajadores en la caba. In: Revista Académica PROCOASAUGM, vol 1, n. 5, ano 5, Noviembre de 2013, p. 104-118. Asociación de Universidades del Grupo Montevideo. Disponível em: <http://revistas.unc.edu.ar/index.php/PROCOASAUGM/article/view/6355/7446 >. Acesso em: 12/12/2013. 